Contract No. DE-FC26-04NT42215

\title{
MICRO-CHP SYSTEM FOR RESIDENTIAL APPLICATIONS
}

\section{Phase I Report}

October 1, 2004 - January 31, 2006

to:

The U.S. Department of Energy National Energy Technology Laboratory

626 Cochrans Mill Road

P.O. Box 10940

Pittsburgh, PA 15326-0940

by:

Joseph Gerstmann

R\&D Manager

Advanced Mechanical Technology

176 Waltham Street

Watertown, MA 02472

Ph: (617) 926-6700; Fax (617) 926-5045

joeg@amtimail.com 


\section{ACKNOWLEDGEMENT}

This report is the result of the efforts of individuals from several organizations who collaborated with AMTI on this project. The contributions of Donald Steele and Keith Robinson of Airxchange; Dr. Charles J. Bishop, Dr. W illiam H. Hoover and Janice Fitzgerald of AO Smith Corporation; Barry M. Cohen of Cohen Creative; Gary R. Papas and Marc A. Annacchino of Marathon Engine System s; and Dr. Roy R. Cr awford of Trane are greatly app reciated. John Corliss, Chuck Hannon and Brady Krass of AMTI also $\mathrm{m}$ ade valuable contributions to the project. The advice and support of Ronald J. Fiskum of the U.S. De partment of Energy, and Douglas F. Gyorke and Mario Sciulli of the National Energy Te chnology Laboratory are gratefully acknowledged.

This report was prepared with the support of the U.S. Depart ment of Energy, under Award No. DE-FC26-04NT42215. However, any opinions, findings, conclusions, or recom mendations expressed herein are those of the author(s) and do not necessarily reflect the views of the DOE. 


\title{
MICRO-CHP SYSTEM FOR RESIDENTIAL APPLICATIONS
}

\author{
$\underline{\text { Phase I Report }}$
}

Table of Contents

List of Figures........................................................................................................................................... iv

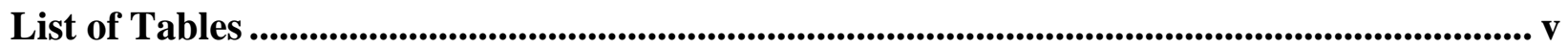

1. Executive Summary ...................................................................................................................... 1

2. Market Characterization..................................................................................................... 5

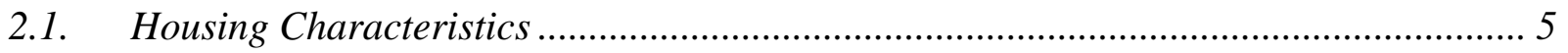

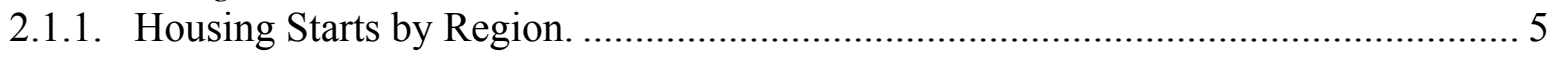

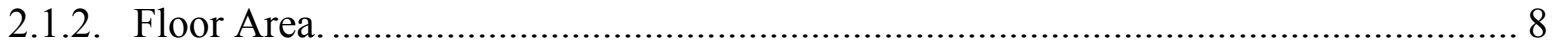

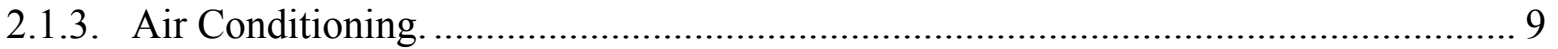

2.1.4. Type of Heating System and Fuel Used ........................................................ 9

2.1.5. Heating and Cooling Loads ............................................................................. 9

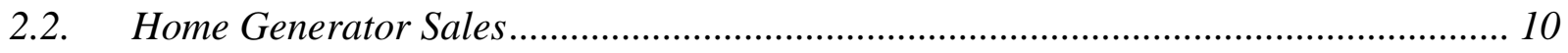

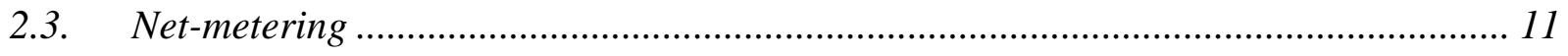

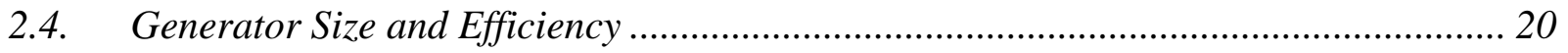

2.5. Spark Spread and Spark Ratio ........................................................................... 26

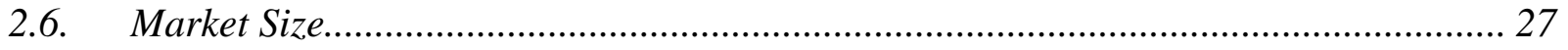

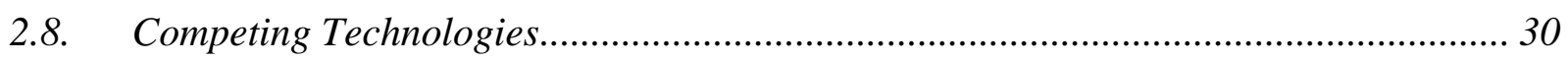

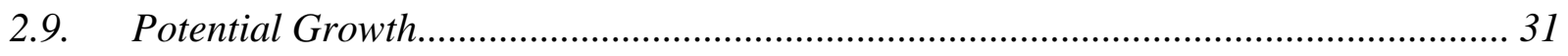

2.10. Market Assessment Conclusions ........................................................................... 31

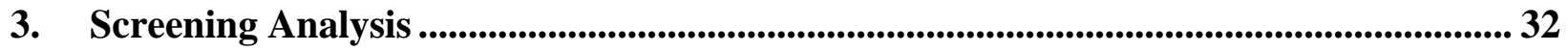

4. Product Characterization................................................................................................... 37

4.1. Performance Requirements............................................................................. 37

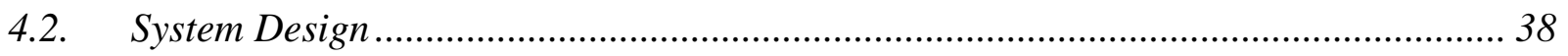

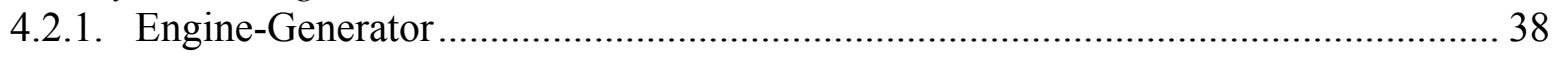

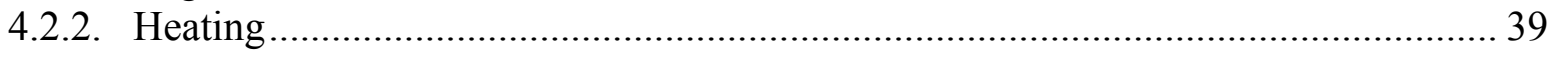

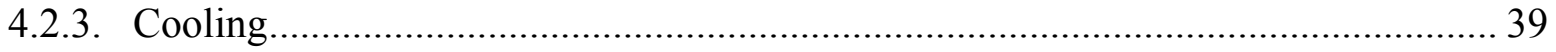

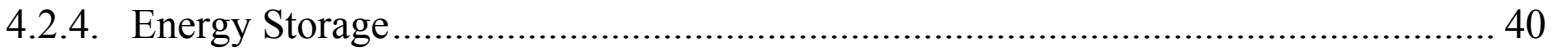




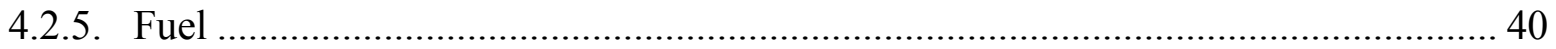

4.2.6. Modular Design .................................................................................................. 40

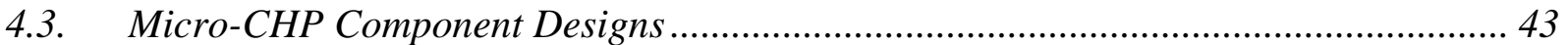

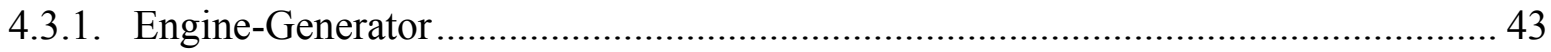

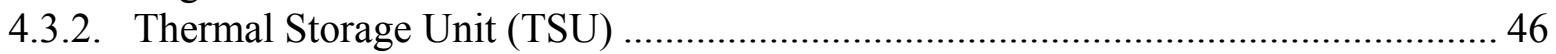

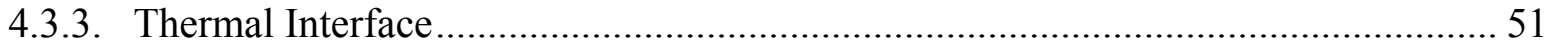

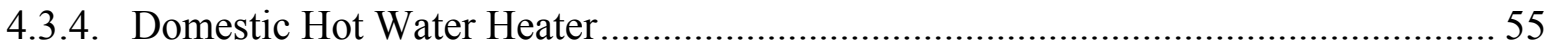

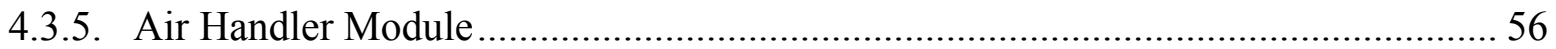

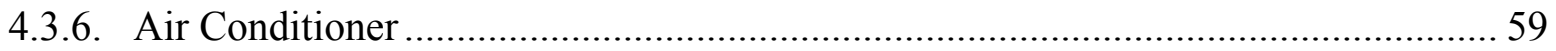

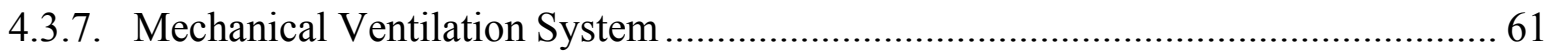

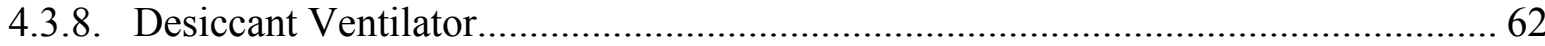

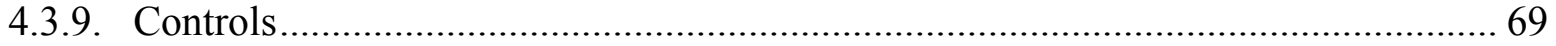

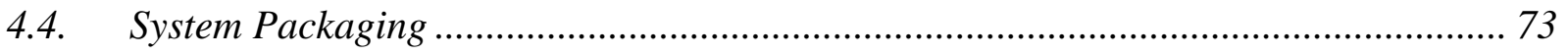

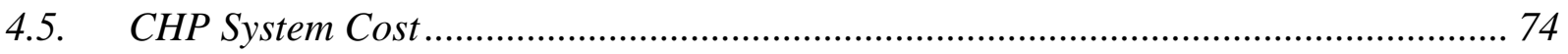

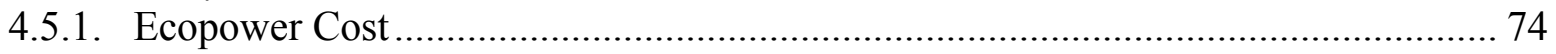

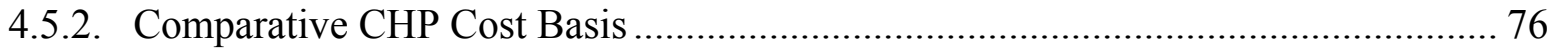

4.5.3. Installed Cost Estimate ……….......................................................................... 77

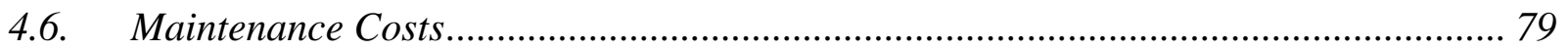

5. Energy Consumption and Operating Cost .................................................................................. 81

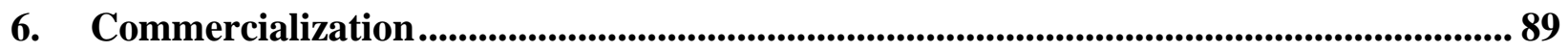

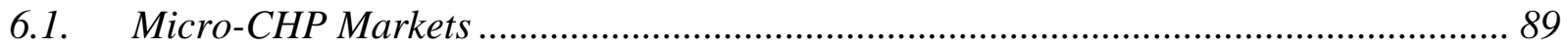

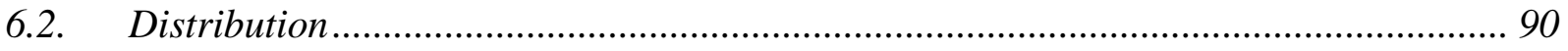

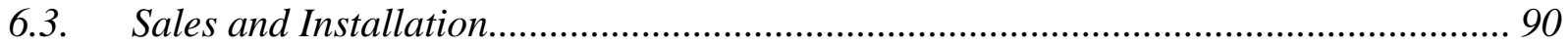

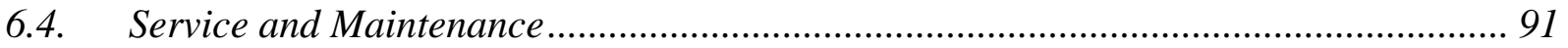

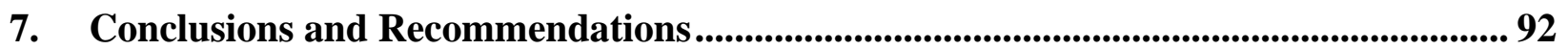




\section{List of Figures}

Figure 1. Production of 1 to $5 \mathrm{~kW}$ Generators.

Figure 2. Generator capacity versus generating efficiency as a function of annual heating loads

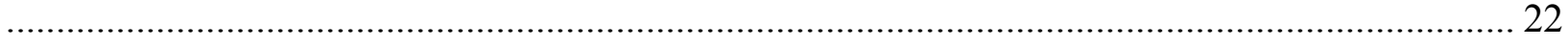

Figure 3. Annual cost savings versus baseline system as a function of annual heating loads..... 23

Figure 4. Annual primary energy savings versus baseline system as a function of annual heating

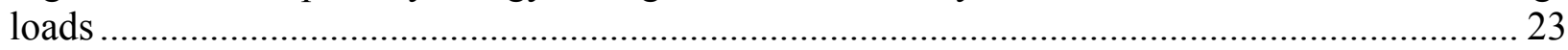

Figure 5. Incremental CHP cost required for a three-year payback ........................................ 24

Figure 6. Annual cost savings versus baseline system as a function of annual heating loads

assuming that zero net metering applies over a six-month heating season.................................... 25

Figure 7. Energy Cost Comparisons of Micro-CHP in 13 Cities ............................................... 34

Figure 8. Primary Energy Savings of CHP systems versus Baseline Systems in 13 Cities ......... 35

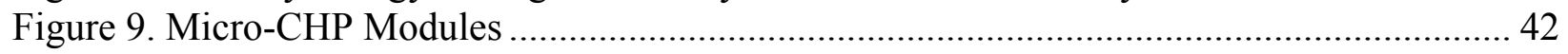

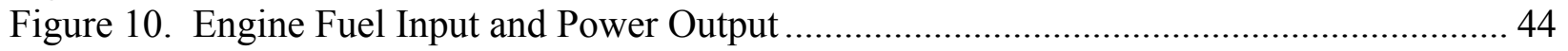

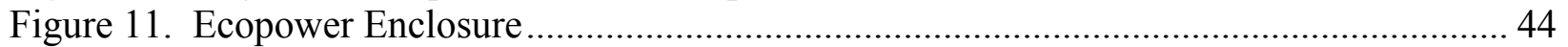

Figure 12. Right Side View of Ecopower Module with Open Side Panels.................................. 45

Figure 13. Left Side View of Ecopower Module with Open Side Panels .................................... 45

Figure 14. Engine Starts versus Heat Load............................................................................. 47

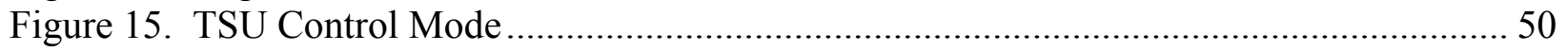

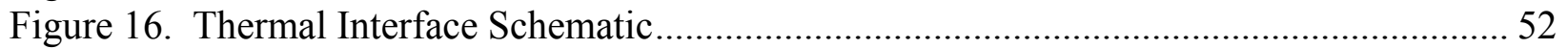

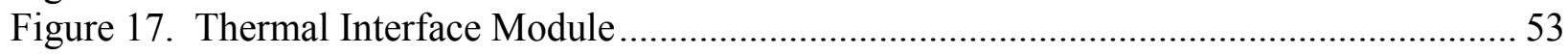

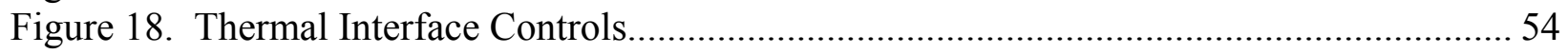

Figure 19. AO Smith Promax ${ }^{\circledR}$ XL circulating loop heat exchanger........................................ 55

Figure 20. RXLD28 Heat Exchanger Performance ………....................................................... 56

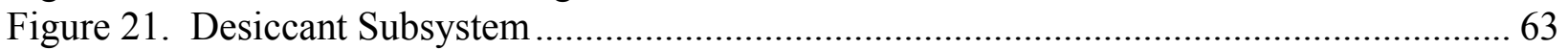

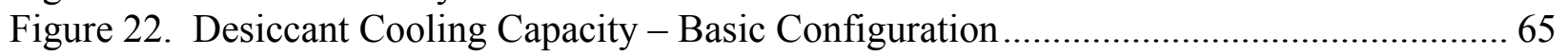

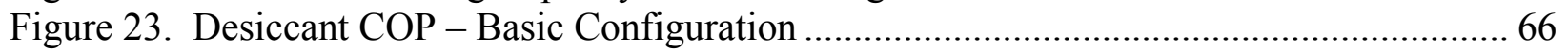

Figure 24. Desiccant Cooling Capacity - Indoor Exhaust Configuration ......................................6 67

Figure 25. Desiccant COP - Indoor Exhaust Configuration......................................................... 67

Figure 26. Grid-Connect Power Conditioning ........................................................................... 71

Figure 27. Continuous Backup Power Conditioning ........................................................... 72

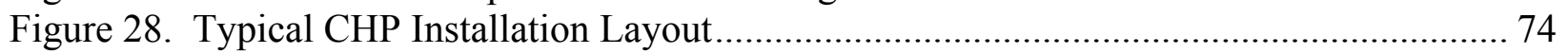

Figure 29. Present Ecopower Cost Breakdown ............................................................. 75

Figure 30. Estimated Cost Breakdown for High-Volume Continuous Backup CHP System ..... 75

Figure 31. Annual Heating and Cooling Loads in 13 Cities..................................................... 83

Figure 32. Source Energy Consumption in 13 Cities ............................................................ 83

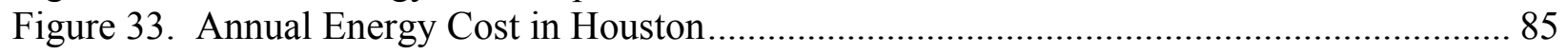

Figure 34. Monthly Source Energy Comparison in Houston ................................................... 85

Figure 35. Monthly Utility Cost Comparison in Houston ............................................................ 86

Figure 36. Electric Consumption by End Use for Baseline "A" in Houston................................. 86

Figure 37. Gas Consumption by End Use for Baseline "A" in Houston ....................................... 87

Figure 38. Electric Consumption by End Use for Gas Micro-CHP in Houston ............................ 87

Figure 39. Gas Consumption by End Use for Gas Micro-CHP in Houston ................................ 88 


\section{$\underline{\text { List of Tables }}$}

Table 1. Average Primary Energy and Cost Savings among 13 Cities .................................. 4

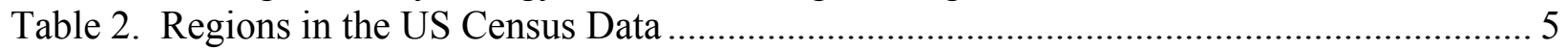

Table 3. Housing Starts in the US (1000 Homes).............................................................. 6

Table 4. Building Permit and Housing Start Data (1000's of Homes) ..................................... 6

Table 5. Estimated Number of New Houses by State (1000's of Homes) ................................. 7

Table 6. Median House Size ................................................................................................. 8

Table 7. Homes Constructed with Air Conditioning, (1000 Homes) ....................................... 9

Table 8. Peak Cooling and Heating Loads for Reference 2,500 sq-ft House ........................... 10

Table 9. Net-metering Regulations: Nine States that Permit Net-metering for Cogeneration; and

States with Net-metering for Other than Cogeneration ................................................... 12

Table 10. Calculated Energy Consumption for Single Family New Construction Homes by

Climate Region ................................................................................................... 21

Table 11. Average Residential Energy Prices in 2001. Source DOE Energy Information

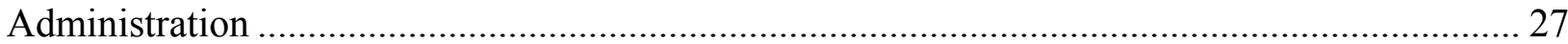

Table 12. Baseline and Micro-CHP systems Used for Energy Consumption Analysis ............. 32

Table 13. Comparison of Energy Consumption and Cost in 13 Cities ................................... 33

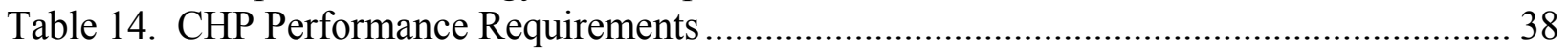

Table 15. Micro-CHP Performance Specifications .......................................................... 42

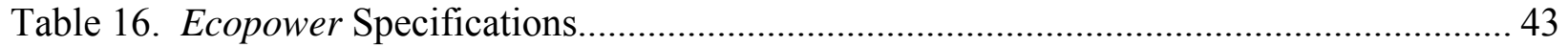

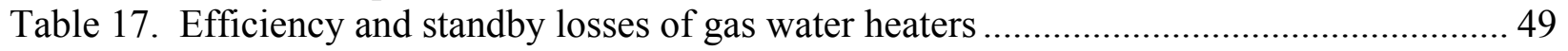

Table 18. Efficiency and standby losses of electric water heaters........................................ 49

Table 19. Estimated Performance of Coolant-to-TSU Heat Exchanger ................................... 51

Table 20. Example of Hydronic Coil Performance at $12.5 \mathrm{~kW}$ Output................................... 57

Table 21. Air Flow Performance of Trane 4TEE3F49A Air Handler .....................................5 58

Table 22. TSU-to-Air Heat Exchanger .................................................................................. 58

Table 23. Trane 4-Ton Variable Capacity Air Conditioner Performance $-1^{\text {st }}$ Stage................. 60

Table 24. Trane 4-Ton Variable Capacity Air Conditioner Performance $-2^{\text {nd }}$ Stage ............... 60

Table 25. Effect of Compressor Capacity and Airflow on Cooling Power .............................. 61

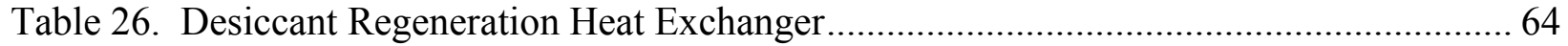

Table 27. Installed Costs of Baseline and CHP Systems ................................................. 78

Table 28. Installed Costs of Baseline and CHP Systems for Equal Generator Costs ................. 79 


\section{Micro-CHP System for Residential Applications}

\section{Executive Summary}

This is the final report of progress under Phase I of a project to develop and commercialize a micro-CHP system for residential applications that provides electrical power, heating, and cooling for the home. This is the first phase of a three-phase effort in which the residential micro-CHP system will be designed (Phase I), developed and tested in the laboratory (Phase II); and further developed and field tested (Phase III).

The project team consists of Advanced Mechanical Technology, Inc. (AMTI), responsible for system design and integration; Marathon Engine Systems, Inc. (MES), responsible for design of the engine-generator subsystem; AO Smith, responsible for design of the thermal storage and water heating subsystems; Trane, a business of American Standard Companies, responsible for design of the HVAC subsystem; and AirXchange, Inc., responsible for design of the mechanical ventilation and dehumidification subsystem.

The Phase I effort consists of the following Tasks and associated objectives:

Task 1. Assessment of Market Requirements

- Develop or utilize a screening tool to determine areas of the country that are most likely to be successful micro-CHP markets.

- Assess the requirements and market sizes for various system configurations and features based on climate and application.

Task 2. Preliminary System Design

- Analyze the micro-CHP system and its major components in detail

- Characterize the performance and operating costs of the candidate systems

Task 3. Detailed System Design

- Prepare a detailed design for a proof-of-concept prototype micro-CHP system.

Task 4. Manufacturing Cost Estimate

- Prepare a detailed manufacturing cost estimate for the system based on the detailed POC design and refined bill of materials.

Task 5. Commercialization Plan

- Develop a commercialization plan for the product.

The market assessment evaluated the size, geographic distribution, energy requirements, and energy supply characteristics of the US housing population. The principal findings and conclusions from the market assessment were that:

- At current gas and electricity prices residential micro-CHP systems are unlikely to achieve short payback periods. In order to justify the higher cost of the CHP capability, 
the system must be capable of providing backup power in the event of an outage of the electric grid.

- Due to the high cost of the micro-CHP system, it will appeal mostly to more affluent buyers who are seeking the security of back-up power, a total-comfort HVAC solution, and who generally own larger-than-average sized homes.

- The primary market will be larger-sized, new-construction, single-family housing, rather than retrofit. Two thirds of the annual 1.5 million new single-family houses are constructed in the southern and western U.S. However, the largest energy and cost savings are in northern homes with significant heating loads.

- In order to achieve positive primary energy savings, the micro-CHP system must follow the thermal load rather than the electrical load. "Net metering"" and a "spark ratio" greater than about 3 are required for this micro-CHP system to show positive operating cost savings.

- Provided there are no restrictions on the sale of surplus electricity generation to the grid, primary energy savings and operating cost savings are generally proportional to electric generating efficiency and to total heat load.

- To minimize cost and to gain acceptance in the marketplace as a reliable, high-quality product, the micro-CHP system needs to be factory engineered and installed and maintained by a qualified installation, service, and maintenance organization.

The micro-CHP system that will meet the requirements of this market will need:

- Sufficient thermal output to satisfy the bulk of the thermal energy requirements of the home. For the above-average house size under consideration, this requires upwards of $12 \mathrm{~kW}(\sim 40,000 \mathrm{Btu} / \mathrm{hr})$ of thermal output. Assuming a ratio of thermal-to-electric output of about $3: 1$, this implies an electrical output of at least $3 \mathrm{~kW}$.

- A cooling capacity of 3 to 5 tons if it is to supply the energy to air condition a 2,500 3,000 sq-ft house.

- The ability to operate grid-parallel or islanded from the grid.

- Thermal storage should be provided to meet varying thermal loads while minimizing engine run-time and on-off cycling.

- Electrical energy storage (batteries) is not required for grid-parallel thermal load following with net-metering, although it may be required for islanded operation.

\footnotetext{
${ }^{1}$ Net metering allows the rate-payer/electricity-generater to export surplus electric power to the utility grid and to deduct the exported power from the amount of power purchased from the utility.

${ }^{2}$ Spark ratio is the ratio of the cost per unit of energy of electricity to that of gas.
} 
The system proposed to meet these requirements is a modular system consisting of:

- A $4.7 \mathrm{kWe}$ generator driven by an efficient, long-life internal-combustion (IC) gas engine supplying a thermal output of $12.5 \mathrm{~kW}$.

- A Thermal Storage Unit (TSU) heated by the engine and supplying hot water to:

o A Domestic Hot Water (DHW) heater

- A hydronic space heating coil coupled to an air handler

o A desiccant dehumidifier/ventilator supplying fresh, dehumidified air to the residence for latent cooling

- A conventional split-system electric air conditioner to provide sensible cooling

- A factory-engineered thermal interface to enable rapid and reliable field installation and connection of the system modules.

The system is based upon the use of a proven, efficient, high-durability gas engine-generator developed specifically for residential energy applications. The engine is manufactured by Marathon Engine Systems in East Troy, WI, and was originally developed to power the Triathlon gas heat pump manufactured by York International. The engine-generator known as the Ecopower is sold in Europe as a co-generation system for hydronic heating and hot water. Its quiet, low-emission, IC engine is capable of operating with natural gas or propane, has a recommended maintenance interval of 4,000 hours, and an expected life of 40,000 hours. The engine is directly coupled to a high-efficiency $4.7-\mathrm{kW}$ generator. $12.5 \mathrm{~kW}$ of thermal energy from the engine's cooling jacket and exhaust is recovered for supplying for heating loads.

The energy and cost performance of the proposed micro-CHP system was estimated for 13 cities across the U.S. using the DOE-2 building energy simulator and cost estimator using the local 2004-2005 residential energy prices. The micro-CHP system's total household energy consumption and energy cost were compared with those of equivalent conventional electric and gas-powered HVAC systems. The average annual electricity generation was $9,160 \mathrm{kWh}$, or an average of $1.05 \mathrm{~kW}$. Peak heating and cooling loads were 88,000 Btu/hr (Chicago) and 55,000 $\mathrm{Btu} / \mathrm{hr}$ (St Louis), respectively.

The average primary energy ${ }^{3}$ and cost savings of the micro-CHP systems among the 13 cities are shown in Table 1. The only difference between the gas and electric micro-CHP systems is in the source of supplementary heating when the thermal output of the micro-CHP system is insufficient for the heating load. The average energy and cost savings of the gas-based microCHP system are $43-95$ MMBtu and \$231 - \$251, respectively. The average savings of the electric-based micro-CHP system are about $40 \mathrm{MMBtu}$ and $\$ 240$ lower. The greatest primary energy savings were in Chicago for the gas micro-CHP versus the baseline electric system (158

\footnotetext{
${ }^{3}$ Primary energy is the en ergy used at the source to provide the energy consumed at the site. The primary energy efficiency assumed for electricity in this case is $33 \%$, to account for generation, transmission and distribution losses; the prime energy efficiency assumed for gas is $100 \%$.
} 
MMBtu); the greatest cost savings were in San Francisco for the gas micro-CHP versus the baseline electric system $(\$ 2,751)$. The weighted average spark ratio and spark spread for the 13 cities were 2.54 and \$16.93/MMBtu, respectively. Detailed results for the 13 cities are contained in the report.

Table 1. Average Primary Energy and Cost Savings among 13 Cities

\begin{tabular}{|c|c|c|c|c|c|}
\hline & \multirow{2}{*}{$\begin{array}{c}\text { Gas } \\
\text { Baseline-A }\end{array}$} & \multirow{2}{*}{$\begin{array}{c}\text { Electric } \\
\text { Baseline-B }\end{array}$} & \multirow{2}{*}{$\begin{array}{c}\text { Gas } \\
\text { Micro-CHP } \\
\text { w/Gas }\end{array}$} & \multirow{2}{*}{$\begin{array}{c}\text { Electric } \\
\text { Micro-CHP } \\
\text { w/Elec }\end{array}$} \\
\hline & & & & & \\
\hline Energy Consumption & MMBtu & 315 & 367 & 272 & 315 \\
\hline Energy Cost & $\$$ & $\$ 3,205$ & $\$ 3,226$ & $\$ 2,974$ & $\$ 3,215$ \\
\hline \multicolumn{6}{|l|}{ Energy Savings: } \\
\hline Gas CHP vs: & MMBtu & 43 & 95 & -- & 43 \\
\hline Electric CHP vs: & MMBtu & 0 & 52 & -43 & -- \\
\hline \multicolumn{6}{|l|}{ Cost Savings: } \\
\hline Gas CHP vs: & $\$$ & $\$ 231$ & $\$ 251$ & -- & $\$ 240$ \\
\hline Electric CHP vs: & $\$$ & $-\$ 9$ & $\$ 11$ & $-\$ 240$ & -- \\
\hline
\end{tabular}

The energy simulation results indicate that, while there is a significant potential for national energy savings, the savings in energy costs are modest, and in some cases negative. Therefore, except in areas where there is a high spark ratio, some sort of energy cost incentive will be needed to justify operation in a CHP mode, rather than just as a backup power system.

While several hundred grid-connected Ecopower units are in operation in Europe, the Ecopower product currently sold in the US is produced in low volumes for specialized, off-grid, niche applications. As such, its pricing reflects one-off component costs and assembly, resulting in an installed cost of approximately $\$ 22,500$. The eventual high-volume installed price of the Ecopower product is estimated to be under $\$ 11,000$. As a continuous backup product that can operate unattended for thousands of hours, at this price the Ecopower should be able to compete with standby generators that are capable of operating at most for only one or two hundred hours without service. At present price levels, the principal markets for this product will be for non-grid-connected remote power applications, where its ability to provide heat and power continuously and reliably with low maintenance requirements justify its premium price. 


\section{Market Characterization}

The objective of this task was to characterize and estimate the size of the market for residential micro-CHP systems. Data was gathered and analyzed to provide information about new housing construction including number of units, average and median size of the housing being built, types of heating equipment installed, type of fuel used in the heating system, net-metering regulations, production of home power generators, and electricity and gas energy prices. These factors were applied to characterize and quantify the market for residential micro-CHP systems.

\subsection{Housing Characteristics}

The primary market for residential micro-CHP is intended to be new construction. The size of this market was estimated from U.S. Census data characterizing the U.S. housing population by region, housing type and size, fuel type, and energy consumption. The U.S. Census collects data on housing and publishes the data in tables giving national totals, rural versus metropolitan overall totals, and by region. Four regions are usually reported including West, South, Midwest and Northeast. States that are included in each of these regions are shown in Table 2.

Table 2. Regions in the US Census Data

\begin{tabular}{|l|ll|ll|ll|}
\hline Northeast & South & & Midwest & & West & \\
\hline Maine & Maryland & Georgia & North & Minnesota & Washington & Nevada \\
New & Delaware & Florida & Dakota & Wisconsin & Idaho & Utah \\
Hampshire & West & Alabama & South & Illinois & Montana & Colorado \\
Vermont & Virginia & Mississippi & Dakota & Michigan & Wyoming & Arizona \\
Massachusetts & Virginia & Arkansas & Nebraska & Indiana & Oregon & New \\
Connecticut & Kentucky & Louisiana & Kansas & Ohio & California & Mexico \\
Rhode Island & Tennessee & Oklahoma & Missouri & & & Alaska \\
New Jersey & North & Texas & Iowa & & & Hawaii \\
New York & Carolina & & & & & \\
Pennsylvania & South & & & & & \\
& Carolina & & & & & \\
& & & & & & \\
& & & & & & \\
\end{tabular}

\subsubsection{Housing Starts by Region.}

Housing start data for single-family homes are available for the years 1959 to 2003 for the four regions. Data are shown in Table 3 for the five-year period from 1999 to 2003 . In the table, the national total is compared with the totals for each of the four regions. This table shows that the overall number of housing starts has been steadily increasing annually since 2000. Moreover, when looking at the regional variations, the south dominates in total number of new starts per year and is showing a greater increase per year than the other regions.

In 2003, there were approximately 1.5 million new houses constructed. New housing starts in the south accounted for 46 percent of these, followed by the West with 26 percent. During the 
four year period from 2000 to 2003, the greatest percentage growth of new starts was in the West at 7.1 percent, followed by the south at 5.5 percent. The northeast showed a negative growth rate on average during this period of -0.4 percent.

Data collected on building permits during the period of 2001 to 2003 closely follows new housing start characteristics. Data on building permits was available on a state-by-state basis. Because the building permit data closely echoed the new housing start data, it was used to estimate housing start values for states within a specific region. This was done by assuming that the state breakdown in building permits applied similarly to a state breakdown in new housing starts.

Table 3. Housing Starts in the US (1000 Homes)

\begin{tabular}{|c|c|c|c|c|c|}
\hline \multirow[b]{2}{*}{ Year } & \multirow[b]{2}{*}{ Total } & \multicolumn{4}{|l|}{ Region } \\
\hline & & Northeast & Midwest & South & West \\
\hline 1999 & 1,302 & 126 & 289 & 580 & 308 \\
\hline 2000 & 1,231 & 118 & 260 & 556 & 297 \\
\hline 2001 & 1,273 & 111 & 269 & 590 & 303 \\
\hline 2002 & 1,359 & 118 & 277 & 628 & 336 \\
\hline 2003 & 1,499 & 116 & 309 & 686 & 388 \\
\hline
\end{tabular}

Regional building permit data and housing start data are compared in Table 4 to show how closely the data sets match. The state-by-state housing start projections for the past four years are shown in Table 5. Housing start data by state for the years 2001-2003 are derived from the building permit data. The data for the year 2000 were estimated by applying the average percentages from 2001 to 2003 for that state within its region to the regional housing start data.

Table 4. Building Permit and Housing Start Data (1000’s of Homes)

\begin{tabular}{|c|c|c|c|c|c|c|}
\hline & \multicolumn{2}{|l|}{2001} & \multicolumn{2}{|l|}{2002} & \multicolumn{2}{|l|}{2003} \\
\hline & \begin{tabular}{|l} 
Permit \\
Data
\end{tabular} & \begin{tabular}{|l|} 
Starts \\
Data
\end{tabular} & $\begin{array}{l}\text { Permit } \\
\text { Data }\end{array}$ & \begin{tabular}{|l|} 
Starts \\
Data
\end{tabular} & $\begin{array}{l}\text { Permit } \\
\text { Data }\end{array}$ & \begin{tabular}{|l|} 
Starts \\
Data
\end{tabular} \\
\hline Total & 1236 & 12731 & 31359 & 911499 & & \\
\hline Northeast & 118 & 11112 & 118124 & & & \\
\hline Midwest & 253 & 26926 & 297287 & & & \\
\hline South & 557 & 59060 & 628701 & & & \\
\hline West & 308 & 30333 & 336379 & & & \\
\hline
\end{tabular}


Table 5. Estimated Number of New Houses by State (1000's of Homes)

\begin{tabular}{|l|l|l|l|l|}
\hline & \multicolumn{4}{|c|}{ Year } \\
& 2000 & 2001 & 2002 & 2003 \\
\hline & & & & \\
\hline Total & 1230.9 & 1273.3 & 1358.6 & 1499.0 \\
\hline & & & & \\
\hline Northeast & 118.3 & 110.8 & 117.8 & 115.9 \\
\hline Connecticut & 7.9 & 7.4 & 7.9 & 7.6 \\
\hline Maine & 6.3 & 5.6 & 6.0 & 6.8 \\
\hline Massachusetts & 12.8 & 12.3 & 12.7 & 12.1 \\
\hline New Hampshire & 6.2 & 5.6 & 6.3 & 6.1 \\
\hline Rhode Island & 2.0 & 2.1 & 2.0 & 1.8 \\
\hline Vermont & 2.3 & 2.2 & 2.3 & 2.3 \\
\hline New Jersey & 21.2 & 20.2 & 20.8 & 20.6 \\
\hline New York & 23.7 & 22.7 & 23.8 & 22.5 \\
\hline Pennsylvania & 35.9 & 32.8 & 36.0 & 35.9 \\
\hline Midwest & 260.4 & 269.3 & 276.7 & 309 \\
\hline Illinois & 41.3 & 42.0 & 44.7 & 48.8 \\
\hline Indiana & 30.9 & 34.5 & 32.3 & 34.3 \\
\hline Michigan & 41.2 & 43.2 & 43.8 & 48.1 \\
\hline Ohio & 39.3 & 41.3 & 41.8 & 45.9 \\
\hline Wisconsin & 26.0 & 27.127 .4 & 30.9 & \\
\hline Iowa & 9.9 & 9.4 & 10.5 & 12.7 \\
\hline Kansas & 10.4 & 10.8 & 10.8 & 12.4 \\
\hline Minnesota & 28.6 & 28.7 & 30.1 & 35.2 \\
\hline Missouri & 20.2 & 20.0 & 21.8 & 24.4 \\
\hline Nebraska & 7.3 & 7.0 & 7.6 & 9.3 \\
\hline North Dakota & 1.8 & 1.6 & 1.9 & 2.5 \\
\hline South Dakota & 3.7 & 3.7 & 4.0 & 4.4 \\
\hline South & 555.6 & 590.3 & 628.2 & 686.3 \\
\hline Delaware & 5.1 & 4.7 & 6.3 & 6.6 \\
\hline DC & 26.8 & 30.5 & 31.1 & 29.9 \\
\hline Florida & 120.3 & 125.8 & 133.3 & 153.7 \\
\hline Georgia & 68.2 & 75.8 & 78.2 & 79.0 \\
\hline Maryland & 21.4 & 25.1 & 24.9 & 22.9 \\
\hline North Carolina & 58.8 & 66.4 & 68.8 & 65.5 \\
\hline South Carolina & 25.3 & 26.3 & 29.6 & 30.9 \\
\hline Virginia & 40.1 & 44.2 & 47.4 & 45.3 \\
\hline West Virginia & 3.8 & 3.7 & 4.7 & 4.6 \\
\hline Alabama & 14.0 & 14.9 & 15.7 & 17.3 \\
\hline Kentucky & 14.6 & 15.9 & 16.9 & 17.1 \\
\hline Mississippi & 8.1 & 8.5 & 9.2 & 9.9 \\
\hline Tennessee & 26.1 & 27.8 & 30.1 & 31.6 \\
\hline & & & & \\
\hline
\end{tabular}




\begin{tabular}{|l|l|l|l|l|}
\hline & \multicolumn{4}{|c|}{ Year } \\
\hline & 2000 & 2001 & 2002 & 2003 \\
\hline Arkansas & 7.6 & 7.9 & 8.3 & 9.9 \\
\hline Louisiana & 13.9 & 14.1 & 15.8 & 18.1 \\
\hline Oklahoma & 10.1 & 10.4 & 11.7 & 12.5 \\
\hline Texas & 110.1 & 118.6 & 127.0 & 131.5 \\
\hline West & 296.5 & 303 & 335.8 & 387.8 \\
\hline Arizona & 50.2 & 50.9 & 55.7 & 67.4 \\
\hline Colorado & 30.8 & 35.8 & 35.0 & 34.6 \\
\hline Idaho & 9.6 & 9.6 & 10.8 & 12.9 \\
\hline Montana & 1.8 & 1.8 & 2.0 & 2.4 \\
\hline Nevada & 25.4 & 26.5 & 27.6 & 33.9 \\
\hline New Mexico & 9.0 & 8.8 & 10.3 & 12.1 \\
\hline Utah & 14.2 & 14.7 & 15.7 & 18.8 \\
\hline Wyoming & 1.6 & 1.51 .82 .3 & \\
\hline Alaska & 1.5 & 1.8 & 1.7 & 1.8 \\
\hline California & 107.0 & 105.5 & 122.9 & 143.1 \\
\hline Hawaii & 4.3 & 4.0 & 4.6 & 6.4 \\
\hline Oregon & 15.0 & 16.0 & 17.4 & 18.3 \\
\hline Washington & 26.1 & 26.330 .2 & 33.9 & \\
\hline
\end{tabular}

\subsubsection{Floor Area.}

Data are available on the size distribution of homes from 1973 to 2003. The style of house, e.g., single story, multi-story, split level etc., is not included in the data. Analyzing the data, we find that the average home size is larger than the median, indicating that the average is skewed by the very large size of some of the above-average sized homes. Median home size was used for comparison between regions, and these data are shown in Table 6 . This table shows that the largest homes are being built in the Northeast and the smallest homes are being built in the Midwest. Interestingly, data for the Northeast in 2003 show a reduction in home size. This could possibly be due to the accelerating cost of land and home construction in New England.

Table 6. Median House Size

\begin{tabular}{|l|l|l|l|l|}
\hline \multirow{2}{*}{ Year } & \multicolumn{4}{|l|}{ Median House Size in Each Region } \\
\cline { 2 - 5 } & Northeast & Midwest & South & West \\
\hline 1999 & 2,175 & 1,937 & 2,044 & 2,001 \\
\hline 2000 & 2,266 & 1,971 & 2,075 & 2,014 \\
\hline 2001 & 2,305 & 1,965 & 2,128 & 2,080 \\
\hline 2002 & 2,330 & 1,979 & 2,120 & 2,127 \\
\hline 2003 & 2,288 & 1,998 & 2,142 & 2,166 \\
\hline
\end{tabular}




\subsubsection{Air Conditioning.}

The presence of air conditioning in new home construction is substantial. The Census data on air conditioning installations is shown in Table 7, and clearly indicates that almost all new homes in the Midwest and south are air conditioned. Only the west has a somewhat low incidence of airconditioned homes at $69 \%$ in 2003.

Table 7. Homes Constructed with Air Conditioning, (1000 Homes)

\begin{tabular}{|l|l|l|l|l|l|l|l|l|l|l|}
\hline \multirow{2}{*}{ Year } & Total US & Northeast & Midwest & \multicolumn{2}{l|}{ South } & \multicolumn{2}{l|}{ West } \\
\cline { 2 - 11 } & Homes & $\%$ & Homes & $\%$ & Homes & $\%$ & Homes & $\%$ & Homes & $\%$ \\
\hline 1999 & 1,072 & $84 \%$ & 85 & $74 \%$ & 241 & $87 \%$ & 566 & $99 \%$ & 181 & $58 \%$ \\
\hline 2000 & 1,060 & $85 \%$ & 88 & $73 \%$ & 239 & $89 \%$ & 562 & $99 \%$ & 171 & $60 \%$ \\
\hline 2001 & 1,081 & $86 \%$ & 86 & $75 \%$ & 230 & $88 \%$ & 575 & $99 \%$ & 189 & $62 \%$ \\
\hline 2002 & 1,155 & $87 \%$ & 87 & $77 \%$ & 242 & $89 \%$ & 611 & $99 \%$ & 215 & $66 \%$ \\
\hline 2003 & 1,223 & $88 \%$ & 89 & $78 \%$ & 253 & $92 \%$ & 632 & $100 \%$ & 249 & $69 \%$ \\
\hline
\end{tabular}

\subsubsection{Type of Heating System and Fuel Used}

Census data were analyzed for type of heating systems installed in new homes and the fuel used. The data are extensive and have not been summarized in a table for this report. However, from the data it is clear that the predominant heating systems being installed in the areas with large home building growth are central duct type systems - gas/electric furnaces and electric heat pumps. This heating system style is compatible with the micro-CHP configurations under consideration.

\subsubsection{Heating and Cooling Loads}

Heating and cooling loads will vary with climate and housing characteristics. An estimate of the range of heating and cooling loads in various climate regions was obtained from the energy simulation modeling that is described in Section 5. Energy use was modeled for a 2,500 sq- $\mathrm{ft}$ house in 13 cities across the country. The maximum hourly heating and cooling loads are listed in Table 8. The largest and smallest peak heating loads are 88,000 Btu/hr in Chicago and 36,000 $\mathrm{Btu} / \mathrm{hr}$ in Miami. The largest and smallest peak cooling loads are 55,000 Btu/hr (4.6 tons) in St. Louis and 36,000 Btu/hr in San Francisco. The median peak cooling and heating loads were about 4 tons and 73,000 Btu/hr, respectively. However, the median seasonal average heating load, assuming a six-month heating season, is considerably lower, at about 32,000 Btu/hr. 
Table 8. Peak Cooling and Heating Loads for Reference 2,500 sq-ft House

\begin{tabular}{|l|c|c|c|}
\hline City & & & \\
& Peak Cooling Btu/h & Peak heating Btu/h & $\begin{array}{c}\text { Average Heating Btu/h } \\
\text { @ 4,380 hrs }\end{array}$ \\
\hline Miami & 54,108 & 35,543 & 1,632 \\
\hline Houston & 53,986 & 67,287 & 10,738 \\
\hline Boston & 39,756 & 81,335 & 41,421 \\
\hline St. Louis & 54,865 & 81,748 & 34,236 \\
\hline Atlanta & 51,653 & 69,631 & 20,537 \\
\hline Memphis & 54,286 & 73,105 & 20,296 \\
\hline Washington DC & 49,426 & 77,334 & 32,769 \\
\hline Chicago & 48,566 & 88,466 & 44,374 \\
\hline Newark NJ & 49,387 & 81,835 & 35,894 \\
\hline Raleigh NC & 50,826 & 73,089 & 23,213 \\
\hline Seattle & 40,507 & 53,746 & 32,096 \\
\hline San Francisco & 36,496 & 42,947 & 18,671 \\
\hline Denver & 37,179 & 75,497 & 39,555 \\
\hline & & & \\
\hline Average & 47,772 & 69,351 & 27,341 \\
\hline Maximum & 54,865 & 88,466 & 44,374 \\
\hline Minimum & 36,496 & 35,543 & 1,632 \\
\hline Median & 49,426 & 73,105 & 32,096 \\
\hline
\end{tabular}

\subsection{Home Generator Sales}

One indicator of sales potential for the micro-CHP is the sales of home generators for backup power. The US Bureau of Commerce tracks manufacturing volume and unit shipments for most products in the United States. Home generators are included in NAICS Code 3353127103 for generators in the size rage of 1 to $5 \mathrm{~kW}$. Data for the years 1996 to 2003 were collected from the Commerce department. These data show an interesting trend (see Figure 1). Production of generators in this size range was high in 1996 and decreased until about 2000. Data were not available for 2001, but were for 2002 and 2003. These years show a growth in production of these units back to 1998 levels.

From the data, we observe that in 2003 , there were 262,364 generators in the $1-5 \mathrm{~kW}$ range manufactured in the US. A total of 14 manufacturers are reported for the data, and the total value of these generators was reported to be $\$ 143,863,000$. The per-generator value was $\$ 548$. These figures do not include production of larger generators.

Kohler Power Systems estimates that the market for home generator sales will increase to two or three times current levels in the immediate future. They report ${ }^{4}$ that homeowners who are

\footnotetext{
${ }^{4}$ J. Custer, "Residential/Light Commercial Standby Power Generators, Kohler Power Systems," presentation to the Technology \& Market Assessment Forum, Energy Solutions Center, October 12-14, 2004, Philadelphia, PA.
} 
susceptible to power outages are most likely to purchase a generator for standby power. Most purchases are made for new construction by buyers with annual incomes of $\$ 200,000$ or more. Price, safety, automatic start, capacity, and response times are given as the most important attributes.

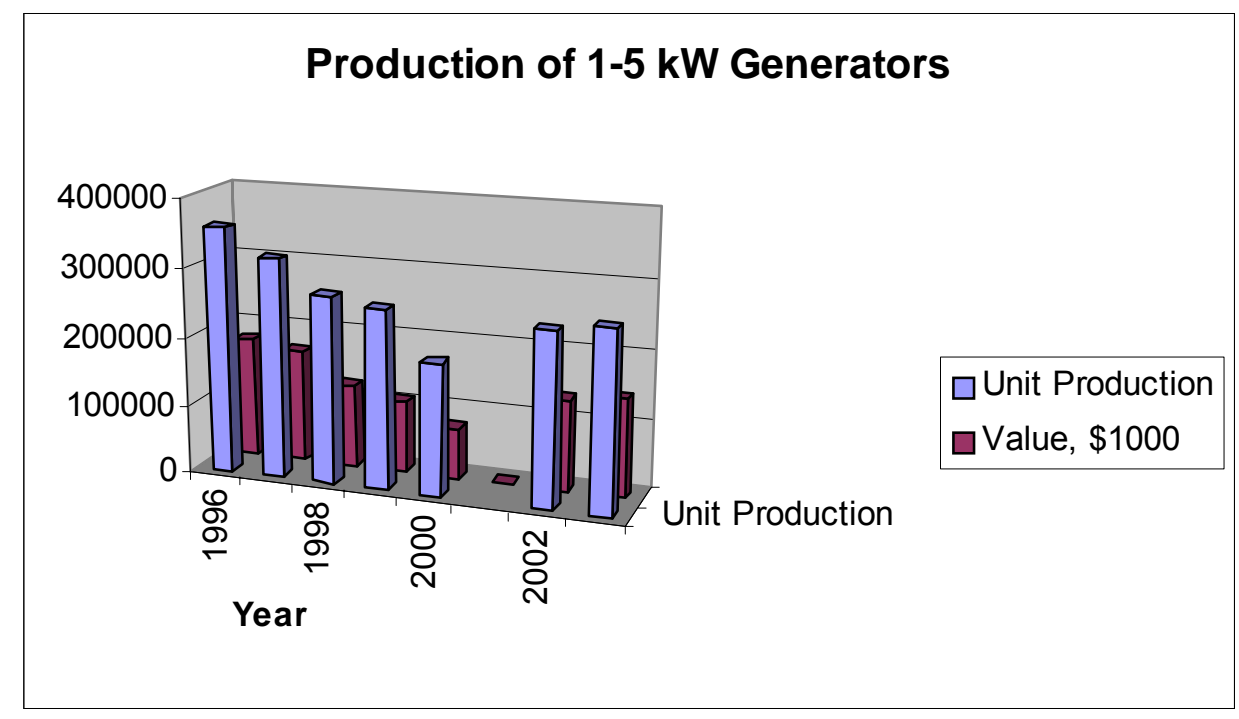

Figure 1. Production of 1 to $5 \mathrm{~kW}$ Generators

\subsection{Net-metering}

Net-metering is the practice of delivering power back to the grid through the same meter that is used to record power usage from the grid. In many cases, net-metering is on a month-to-month basis wherein the amount of power delivered back to the grid is compared to the power consumed and reconciled for the month. Usually no net sales to the utility are allowed, but in some cases it is. Also, there is generally no carry-over from month to month, so if a customer has excess power that is generated and they are not permitted to be a net producer, this excess power is not credited in future months.

Most states permit some form of net-metering, but the regulations are typically technology dependent. As of July, 2004, only nine states permitted net-metering with cogeneration systems. Many states only permit it for biomass fuels and other renewables, fuel cells, and microturbines. Table 9 summarizes the net-metering regulations in the nine states that currently (as of July 2004) permit it for cogeneration, and also includes a summary of the regulations in the other states.

The Energy Policy Act of 2005 amended the Public Utilities Regulatory Policies Act (PURPA) to require every public utility to offer interconnection to the power grid and net metering upon request, to take effect by 2008 . Thus, as this technology moves into the marketplace, many other states will adopt regulations for net-metering with cogeneration. 
Table 9. Net-metering Regulations: Nine States that Permit Net-metering for Cogeneration; and States with Net-metering for Other than Cogeneration

\begin{tabular}{|c|c|c|c|c|}
\hline State & $\begin{array}{l}\text { System Size Limit/ } \\
\text { Customer Classes }\end{array}$ & Eligible Technologies & Treatment of Net Excess Generation & \begin{tabular}{|l} 
Utilities \\
Involved
\end{tabular} \\
\hline \multicolumn{5}{|c|}{ States with Net-metering for Cogeneration } \\
\hline $\begin{array}{l}\text { Maine (Net } \\
\text { Energy } \\
\text { Billing) }\end{array}$ & $\begin{array}{c}100 \mathrm{~kW} \\
\text { Commercial, Industrial, } \\
\text { Residential }\end{array}$ & $\begin{array}{l}\text { Solar Thermal Electric, Photovoltaic, Wind, } \\
\text { Biomass, Hydroelectric, Geothermal } \\
\text { Electric, Fuel Cells Municipal Solid Waste, } \\
\text { Cogeneration, Tidal Energy }\end{array}$ & $\begin{array}{l}\text { Credited to the following month, then } \\
\text { granted to the utility at the end of annual } \\
\text { period with no compensation }\end{array}$ & All Utilities \\
\hline Massachusetts & $\begin{array}{c}60 \mathrm{~kW} \\
\text { Commercial, Industrial, } \\
\text { Residential }\end{array}$ & $\begin{array}{l}\text { Solar Thermal Electric, Photovoltaic, Wind, } \\
\text { Biomass, Hydroelectric, Geothermal } \\
\text { Electric, Fuel Cells Municipal Solid Waste, } \\
\text { Cogeneration }\end{array}$ & Purchased at avoided cost monthly & All Utilities \\
\hline Minnesota & $\begin{array}{c}40 \mathrm{~kW} \\
\begin{array}{c}\text { Commercial, Industrial, } \\
\text { Residential }\end{array} \\
\end{array}$ & $\begin{array}{l}\text { Photovoltaic, Wind, Biomass, } \\
\text { Hydroelectric, Municipal Solid Waste, } \\
\text { Cogeneration }\end{array}$ & $\begin{array}{l}\text { Purchased at average retail utility } \\
\text { energy rate }\end{array}$ & All Utilities \\
\hline New Mexico & $\begin{array}{c}10 \mathrm{~kW} \\
\text { Commercial, Industrial, } \\
\text { Residential }\end{array}$ & $\begin{array}{l}\text { Solar Thermal Electric, Photovoltaic, } \\
\text { Landfill Gas, Wind, Biomass, } \\
\text { Hydroelectric, Geothermal Electric, Fuel } \\
\text { Cells Municipal Solid Waste, Cogeneration, } \\
\text { Microturbines }\end{array}$ & $\begin{array}{l}\text { Avoided cost or credited to the } \\
\text { following month }\end{array}$ & $\begin{array}{l}\text { All IOU's } \\
\text { and Co-Ops }\end{array}$ \\
\hline Oklahoma & $\begin{array}{l}\text { Smaller of size limit of } \\
100 \mathrm{~kW} \text { or production } \\
\text { limit of } 25,000 \mathrm{~kW}- \\
\mathrm{Hrs} / \mathrm{Yr}\end{array}$ & $\begin{array}{l}\text { Solar Thermal Electric, Photovoltaic, Wind, } \\
\text { Biomass, Hydroelectric, Geothermal } \\
\text { Electric, Fuel Cells Municipal Solid Waste, } \\
\text { Cogeneration }\end{array}$ & $\begin{array}{l}\text { Most often granted to utility monthly; } \\
\text { some programs roll over excess to next } \\
\text { month }\end{array}$ & All Utilities \\
\hline Rhode Island & $\begin{array}{c}25 \mathrm{~kW} \\
\text { Commercial, Industrial, } \\
\text { Residential }\end{array}$ & $\begin{array}{l}\text { Solar Thermal Electric, Photovoltaic, Wind, } \\
\text { Biomass, Hydroelectric, Geothermal } \\
\text { Electric, Fuel Cells Municipal Solid Waste, } \\
\text { Cogeneration }\end{array}$ & $\begin{array}{l}\text { Excess kW-hr credited on following } \\
\text { month's bill; granted to utility at end of } \\
\text { 12-month period }\end{array}$ & $\begin{array}{l}\text { Narragansett } \\
\text { Electric }\end{array}$ \\
\hline Wisconsin & $\begin{array}{c}20 \mathrm{~kW} \\
\begin{array}{c}\text { Commercial, Industrial, } \\
\text { Residential }\end{array} \\
\end{array}$ & $\begin{array}{l}\text { Solar Thermal Electric, Photovoltaic, Wind, } \\
\text { Biomass, Hydroelectric, Geothermal } \\
\text { Electric, Fuel Cells Municipal Solid Waste, }\end{array}$ & $\begin{array}{l}\text { Purchased at retail rate for renewables, } \\
\text { avoided cost for non-renewables }\end{array}$ & $\begin{array}{l}\text { Investor- } \\
\text { owned } \\
\text { utilities only } \\
\end{array}$ \\
\hline
\end{tabular}




\begin{tabular}{|c|c|c|c|c|}
\hline State & $\begin{array}{l}\text { System Size Limit/ } \\
\text { Customer Classes }\end{array}$ & Eligible Technologies & Treatment of Net Excess Generation & $\begin{array}{l}\text { Utilities } \\
\text { Involved }\end{array}$ \\
\hline & & Cogeneration & & \\
\hline Colorado & "small generators" & Cogen and others & $\begin{array}{l}\text { No compensation, calculated on the } \\
\text { billing cycle }\end{array}$ & $\begin{array}{l}\text { Only a few } \\
\text { utilities }\end{array}$ \\
\hline Idaho & $100 \mathrm{~kW}$ & Cogen and others & $\begin{array}{l}\text { Purchased at avoided cost. Extra } \\
\text { monthly charge to recover the non- } \\
\text { generation-related cost of the utility }\end{array}$ & IOU only \\
\hline \multicolumn{5}{|c|}{ States with Net-metering Regulations that Do Not Presently Include Cogeneration } \\
\hline $\begin{array}{c}\text { Tucson } \\
\text { Electric Power }\end{array}$ & $\begin{array}{c}10 \mathrm{~kW} \\
\text { Commercial, } \\
\text { Residential } \\
\end{array}$ & Photovoltaics, Wind & \begin{tabular}{|c|} 
Monthly excess kWh carried forward to \\
next billing cycle; net excess at end of \\
year granted to utility \\
\end{tabular} & TEP \\
\hline $\begin{array}{l}\text { Arizona - } \\
\text { Salt River } \\
\text { Project } \\
\end{array}$ & $\begin{array}{c}10 \mathrm{~kW} \\
\text { Residential Only }\end{array}$ & Photovoltaics & $\begin{array}{c}\text { Purchased monthly by utility at average } \\
\text { monthly market price minus a price } \\
\text { adjustment of } \$ 0.00017 / \mathrm{kWh}\end{array}$ & SRP \\
\hline Arkansas & $\begin{array}{l}25 \mathrm{~kW} \text { for residential } \\
\text { systems; } 100 \mathrm{~kW} \text { for } \\
\text { commercial systems }\end{array}$ & $\begin{array}{c}\text { Solar Thermal Electric, Photovoltaics, } \\
\text { Wind, Biomass, Hydroelectric, Geothermal } \\
\text { Electric, Fuel Cells, Microturbines using } \\
\text { renewable fuels }\end{array}$ & Granted to the utility monthly & All utilities \\
\hline California & $\begin{array}{c}\text { MW } \\
\text { Commercial, Industrial, } \\
\text { Residential } \\
\end{array}$ & $\begin{array}{c}\text { Photovoltaics, Landfill Gas, Wind, Solar, } \\
\text { Anaerobic Digestion }\end{array}$ & Granted to utility annually & $\begin{array}{l}\text { IOUs; } \\
\text { Municipal } \\
\text { utilities } \\
\end{array}$ \\
\hline $\begin{array}{l}\text { Colorado - } \\
\text { Fort Collins } \\
\text { Utilities } \\
\end{array}$ & $\begin{array}{c}3 \mathrm{~kW} \\
\text { Commercial, Industrial, } \\
\text { Residential }\end{array}$ & Photovoltaics, Wind & $\begin{array}{l}\text { Purchased at avoided cost on a monthly } \\
\text { basis }\end{array}$ & $\begin{array}{c}\text { Fort Collins } \\
\text { Utilities }\end{array}$ \\
\hline $\begin{array}{l}\text { Colorado - } \\
\text { Aspen } \\
\text { Electric/Holy } \\
\text { Cross Electric }\end{array}$ & $\begin{array}{c}\text { No size limit on } \\
\text { individual systems; } \\
\text { Commercial, Industrial, } \\
\text { Residential } \\
\end{array}$ & Photovoltaics & Customers receive full retail credit & $\begin{array}{l}\text { Aspen } \\
\text { Electric, } \\
\text { Holy Cross } \\
\text { Electric } \\
\end{array}$ \\
\hline $\begin{array}{l}\text { Colorado - } \\
\text { Xcel Energy }\end{array}$ & $\begin{array}{c}\text { Smaller than } 10 \mathrm{~kW} \\
\text { Commercial, } \\
\text { Residential } \\
\end{array}$ & Photovoltaics, Wind, Small Hydroelectric & Carried forward to next month & Xcel Energy \\
\hline
\end{tabular}




\begin{tabular}{|c|c|c|c|c|}
\hline State & $\begin{array}{l}\text { System Size Limit/ } \\
\text { Customer Classes }\end{array}$ & Eligible Technologies & Treatment of Net Excess Generation & $\begin{array}{l}\text { Utilities } \\
\text { Involved }\end{array}$ \\
\hline $\begin{array}{l}\text { Colorado - } \\
\text { Gunnison } \\
\text { County } \\
\text { Electric } \\
\end{array}$ & $\begin{array}{c}10 \mathrm{~kW} \\
\text { Commercial, } \\
\text { Residential }\end{array}$ & Photovoltaics, Wind & $\begin{array}{c}\text { Purchased by utility at retail rate until } \\
\text { the meter reads zero and then purchased } \\
\text { at wholesale rate of } 3.5 \text { cents }\end{array}$ & $\begin{array}{c}\text { Gunnison } \\
\text { County EMC }\end{array}$ \\
\hline Connecticut & $\begin{array}{c}\text { Fossil technologies: } 50 \\
\text { kW; Renewable } \\
\text { technologies: } 100 \mathrm{~kW} \text {; } \\
\text { Residential, Multi- } \\
\text { Family Residential, } \\
\text { (multi-family of 2-4 } \\
\text { units) } \\
\end{array}$ & $\begin{array}{c}\text { Solar Thermal Electric, Photovoltaics, } \\
\text { Landfill Gas, Wind, Biomass, Fuel Cells, } \\
\text { Municipal Solid Waste, Small } \\
\text { Hydroelectric, Tidal Energy, Wave Energy, } \\
\text { Ocean Thermal }\end{array}$ & $\begin{array}{l}\text { Purchased by utility at spot market } \\
\text { energy rate }\end{array}$ & $\begin{array}{l}\text { Investor- } \\
\text { owned } \\
\text { utilities only }\end{array}$ \\
\hline Delaware & $\begin{array}{c}25 \mathrm{~kW} \\
\text { Commercial, } \\
\text { Residential }\end{array}$ & $\begin{array}{c}\text { Solar Thermal Electric, Photovoltaics, } \\
\text { Wind, Biomass, Hydroelectric, Geothermal } \\
\text { Electric }\end{array}$ & $\begin{array}{l}\text { Varies by utility (see DSIRE for } \\
\text { discussion) }\end{array}$ & $\begin{array}{c}\text { Conectiv } \\
\text { Power } \\
\text { Delivery } \\
\text { (Conectiv) } \\
\text { and } \\
\text { Delaware } \\
\text { Electric } \\
\text { Cooperative } \\
\text { (DEC) }\end{array}$ \\
\hline $\begin{array}{l}\text { District of } \\
\text { Columbia } \\
\text { (Rules have } \\
\text { never been } \\
\text { issued by DC } \\
\text { PSC) } \\
\end{array}$ & $\begin{array}{c}100 \mathrm{~kW} \\
\text { Commercial, Industrial, } \\
\text { Residential }\end{array}$ & $\begin{array}{l}\text { Solar Thermal Electric, Photovoltaics, } \\
\text { Wind, Biomass, Fuel Cells, Microturbines }\end{array}$ & $\begin{array}{c}\text { Not specified } \\
\text { (Rules have never been issued by DC } \\
\text { PSC) }\end{array}$ & All utilities \\
\hline $\begin{array}{c}\text { Florida - } \\
\text { New Smyrna } \\
\text { Beach Utilities } \\
\text { Commission } \\
\end{array}$ & $\begin{array}{c}\text { No stated system size } \\
\text { limit; } \\
\text { Commercial, Industrial, } \\
\text { Residential } \\
\end{array}$ & Photovoltaics & & $\begin{array}{l}\text { New Smyrna } \\
\text { Beach } \\
\text { Utilities }\end{array}$ \\
\hline Florida - & $10 \mathrm{~kW}$ & Photovoltaics, Wind & Carried forward to next month & JEA \\
\hline
\end{tabular}




\begin{tabular}{|c|c|c|c|c|}
\hline State & $\begin{array}{l}\text { System Size Limit/ } \\
\text { Customer Classes }\end{array}$ & Eligible Technologies & Treatment of Net Excess Generation & $\begin{array}{l}\text { Utilities } \\
\text { Involved }\end{array}$ \\
\hline JEA & Residential Only & & & \\
\hline Georgia & $\begin{array}{l}10 \mathrm{~kW} \text { for residential } \\
\text { systems and } 100 \mathrm{~kW} \text { for } \\
\text { commercial systems }\end{array}$ & Photovoltaics, Wind, Fuel Cells & $\begin{array}{l}\text { Credited to the following month, then } \\
\text { granted to the utility at end of annual } \\
\text { period with no compensation }\end{array}$ & All utilities \\
\hline Hawaii & $\begin{array}{c}50 \mathrm{~kW} \\
\text { Commercial, } \\
\text { Residential }\end{array}$ & $\begin{array}{c}\text { Photovoltaics, Wind, Biomass, } \\
\text { Hydroelectric }\end{array}$ & Granted to utility monthly & All utilities \\
\hline $\begin{array}{c}\text { Illinois - } \\
\text { ComEd } \\
\text { (Wind - PV } \\
\text { Generation } \\
\text { Pricing } \\
\text { Experiment) }\end{array}$ & $\begin{array}{c}40 \mathrm{~kW} \\
\text { Commercial, Industrial, } \\
\text { Residential, (All } \\
\text { ComEd Retail } \\
\text { Customers only) }\end{array}$ & Photovoltaics, Wind, Biomass & $\begin{array}{l}\text { Purchased at avoided cost, plus an } \\
\text { annual incentive payment }\end{array}$ & ComEd \\
\hline $\begin{array}{c}\text { Indiana } \\
\text { (Current Net } \\
\text { Billing Rules; } \\
\text { new Net- } \\
\text { metering rules } \\
\text { under review) }\end{array}$ & $\begin{array}{l}\text { 1,000 kWh/month } \\
\text { Commercial, } \\
\text { Residential }\end{array}$ & Renewable Energy Systems & Granted to utility & $\begin{array}{l}\text { Investor- } \\
\text { owned } \\
\text { utilities only }\end{array}$ \\
\hline Iowa & $\begin{array}{c}500 \mathrm{~kW} \text { for } \\
\text { MidAmerican Energy; } \\
\text { Commercial, Industrial, } \\
\text { Residential } \\
\text { (a similar limit is under } \\
\text { consideration for } \\
\text { Interstate Power and } \\
\text { Light) }\end{array}$ & $\begin{array}{c}\text { Photovoltaics, Wind, Biomass, } \\
\text { Hydroelectric, Municipal Solid Waste }\end{array}$ & $\begin{array}{l}\text { Purchased at avoided cost; } \\
\text { MidAmerican Energy carries forward } \\
\text { excess amounts for use in future months }\end{array}$ & $\begin{array}{l}\text { Investor- } \\
\text { owned } \\
\text { utilities only }\end{array}$ \\
\hline $\begin{array}{c}\text { Kentucky - } \\
\text { Berea College } \\
\text { Utilities Pilot } \\
\text { Program } \\
\end{array}$ & $\begin{array}{l}10 \mathrm{~kW} \text { (residents) and } \\
25 \mathrm{~kW} \text { (non-residents) }\end{array}$ & Photovoltaics, Wind, Small Hydroelectric & Credited to the following month & $\begin{array}{c}\text { Berea } \\
\text { College } \\
\text { Utilities }\end{array}$ \\
\hline
\end{tabular}




\begin{tabular}{|c|c|c|c|c|}
\hline State & $\begin{array}{l}\text { System Size Limit/ } \\
\text { Customer Classes }\end{array}$ & Eligible Technologies & Treatment of Net Excess Generation & $\begin{array}{l}\text { Utilities } \\
\text { Involved }\end{array}$ \\
\hline $\begin{array}{l}\text { Kentucky - } \\
\text { ULH\&P Pilot } \\
\text { Program }\end{array}$ & $\begin{array}{c}20 \mathrm{~kW} \text { (may not } \\
\text { generate more than } \\
1,000 \mathrm{kWh} \text { per month) } \\
\text { Residential, Schools } \\
\end{array}$ & Photovoltaics, Wind, Small Hydroelectric & Credited to the following month & ULH\&P \\
\hline $\begin{array}{c}\text { Kentucky - } \\
\text { Kentucky } \\
\text { Utilities (KU) } \\
\text { Pilot Program }\end{array}$ & $\begin{array}{l}10 \mathrm{~kW} \text { (residents) and } \\
25 \mathrm{~kW} \text { (non-residents) }\end{array}$ & Photovoltaics, Wind, Small Hydroelectric & Credited to the following month & $\begin{array}{l}\text { Kentucky } \\
\text { Utilities } \\
(\mathrm{KU})\end{array}$ \\
\hline $\begin{array}{l}\text { Kentucky - } \\
\text { LG\&E Pilot } \\
\text { Program }\end{array}$ & $\begin{array}{l}10 \mathrm{~kW} \text { (residents) and } \\
25 \mathrm{~kW} \text { (non-residents) }\end{array}$ & Photovoltaics, Wind, Small Hydroelectric & Credited to the following month & LG\&E \\
\hline $\begin{array}{l}\text { Kentucky } \\
\text { (legislation } \\
\text { passed in April } \\
\text { 2004; rules to } \\
\text { be developed) } \\
\end{array}$ & $\begin{array}{c}15 \mathrm{~kW} \\
\text { Commercial, } \\
\text { Residential, Nonprofit, } \\
\text { Schools, Agricultural, } \\
\text { Institutional } \\
\end{array}$ & Photovoltaics & $\begin{array}{l}\text { Credited to following month; no } \\
\text { expiration }\end{array}$ & $\begin{array}{l}\text { All IOUs } \\
\text { and Coops }\end{array}$ \\
\hline $\begin{array}{c}\text { Louisiana } \\
\text { (rules under } \\
\text { development) }\end{array}$ & $\begin{array}{l}25 \mathrm{~kW} \text { for residential } \\
\text { systems; } 100 \mathrm{~kW} \text { for } \\
\text { commercial \& } \\
\text { agricultural systems }\end{array}$ & $\begin{array}{c}\text { Photovoltaics, Wind, Biomass, } \\
\text { Hydroelectric, Geothermal Electric, Fuel } \\
\text { Cells with Renewable Fuels, Microturbines }\end{array}$ & (rules under development) & All utilities \\
\hline Maryland & $\begin{array}{c}80 \mathrm{~kW} \\
\text { Commercial, } \\
\text { Residential, Schools, } \\
\text { Local Government, } \\
\text { State Government, Fed. } \\
\text { Government } \\
\end{array}$ & Photovoltaics, Wind & $\begin{array}{l}\text { To be determined by Public Service } \\
\text { Commission }\end{array}$ & All utilities \\
\hline $\begin{array}{c}\text { Michigan } \\
\text { (May 2004 } \\
\text { Order to begin } \\
\text { developing } \\
\text { rules) } \\
\end{array}$ & $\begin{array}{l}\text { No size limit specified } \\
\text { yet; } \\
\text { residential and small } \\
\text { commercial customers }\end{array}$ & Renewable energy & (rules under development) & $\begin{array}{l}\text { All IOUs \& } \\
\text { Co-ops }\end{array}$ \\
\hline
\end{tabular}




\begin{tabular}{|c|c|c|c|c|}
\hline State & $\begin{array}{l}\text { System Size Limit/ } \\
\text { Customer Classes }\end{array}$ & Eligible Technologies & Treatment of Net Excess Generation & $\begin{array}{l}\text { Utilities } \\
\text { Involved }\end{array}$ \\
\hline $\begin{array}{l}\text { Montana- } \\
\text { Montana } \\
\text { Electric } \\
\text { Cooperatives }\end{array}$ & $\begin{array}{c}10 \mathrm{~kW} \\
\text { Commercial, } \\
\text { Residential }\end{array}$ & $\begin{array}{l}\text { Photovoltaics, Wind, Geothermal Electric, } \\
\text { Fuel Cells, Small Hydroelectric }\end{array}$ & $\begin{array}{l}\text { Credited to the following month, then } \\
\text { granted to the utility at end of the annual } \\
\text { period with no compensation }\end{array}$ & $\begin{array}{c}\text { Most of } \\
\text { MECA's } 26 \\
\text { member } \\
\text { electric } \\
\text { cooperatives }\end{array}$ \\
\hline Montana & $\begin{array}{c}50 \mathrm{~kW} \\
\text { Commercial, Industrial, } \\
\text { Residential }\end{array}$ & Photovoltaics, Wind, Hydroelectric & $\begin{array}{l}\text { Credited to the following month, then } \\
\text { granted to the utility at end of annual } \\
\text { period with no compensation }\end{array}$ & $\begin{array}{c}\text { Any IOU } \\
\text { Montana- } \\
\text { Dakota } \\
\text { Utility } \\
\text { (MDU) \& } \\
\text { NorthWester } \\
\text { n Energy } \\
\text { (NWE) }\end{array}$ \\
\hline Nevada & $\begin{array}{c}30 \mathrm{~kW} \\
\begin{array}{c}\text { Commercial, Industrial, } \\
\text { Residential }\end{array} \\
\end{array}$ & $\begin{array}{c}\text { Solar Thermal Electric, Photovoltaics, } \\
\text { Wind, Biomass, Hydroelectric, Geothermal } \\
\text { Electric }\end{array}$ & Granted to utility & $\begin{array}{c}\text { Investor- } \\
\text { owned } \\
\text { utilities only }\end{array}$ \\
\hline $\begin{array}{c}\text { New } \\
\text { Hampshire }\end{array}$ & $\begin{array}{c}25 \mathrm{~kW} \\
\text { Commercial, Industrial, } \\
\text { Residential }\end{array}$ & Photovoltaics, Wind, Hydroelectric & $\begin{array}{l}\text { Excess kWhs credited to following } \\
\text { month }\end{array}$ & All utilities \\
\hline New Jersey & $\begin{array}{l}\text { 100kW } \\
\text { Commercial, } \\
\text { Residential }\end{array}$ & Photovoltaics, Wind & $\begin{array}{l}\text { Credited to following month; unused } \\
\text { credit purchased at avoided cost at end } \\
\text { of annualized period }\end{array}$ & All utilities \\
\hline New York & $\begin{array}{l}10 \mathrm{~kW} \text { (solar); } 400 \mathrm{~kW} \\
\text { (farm waste electric } \\
\text { generating equipment) }\end{array}$ & $\begin{array}{l}\text { Photovoltaics, Biomass } \\
\text { (Wind legislation pending) }\end{array}$ & Purchased at avoided cost & All utilities \\
\hline North Dakota & $\begin{array}{c}100 \mathrm{~kW} \\
\text { Commercial, Industrial, } \\
\text { Residential }\end{array}$ & $\begin{array}{c}\text { Solar Thermal Electric, Photovoltaics, } \\
\text { Wind, Biomass, Hydroelectric, Geothermal } \\
\text { Electric, Municipal Solid Waste, } \\
\text { Cogeneration }\end{array}$ & Purchased at avoided cost & $\begin{array}{c}\text { Investor- } \\
\text { owned } \\
\text { utilities only }\end{array}$ \\
\hline $\begin{array}{c}\text { Ohio - } \\
\text { Bowling Green }\end{array}$ & $\begin{array}{c}25 \mathrm{~kW} \\
\text { Commercial, }\end{array}$ & $\begin{array}{l}\text { Photovoltaics, Wind, Hydroelectric, Fuel } \\
\text { Cells }\end{array}$ & Not specified & $\begin{array}{l}\text { Bowling } \\
\text { Green }\end{array}$ \\
\hline
\end{tabular}




\begin{tabular}{|c|c|c|c|c|}
\hline State & $\begin{array}{l}\text { System Size Limit/ } \\
\text { Customer Classes }\end{array}$ & Eligible Technologies & Treatment of Net Excess Generation & $\begin{array}{l}\text { Utilities } \\
\text { Involved }\end{array}$ \\
\hline $\begin{array}{c}\text { Municipal } \\
\text { Utilities }\end{array}$ & Residential & & & $\begin{array}{l}\text { Municipal } \\
\text { Utilities }\end{array}$ \\
\hline Ohio & $\begin{array}{l}100 \mathrm{~kW} \text { limit on } \\
\text { microturbines; no limit } \\
\text { on other eligible } \\
\text { systems; } \\
\text { Commercial, Industrial, } \\
\text { Residential } \\
\end{array}$ & $\begin{array}{l}\text { Solar Thermal Electric, Photovoltaics, } \\
\text { Landfill Gas, Wind, Biomass, } \\
\text { Hydroelectric, Fuel Cells, Microturbines }\end{array}$ & $\begin{array}{l}\text { Purchased at utility's unbundled } \\
\text { generation rate }\end{array}$ & $\begin{array}{l}\text { Investor- } \\
\text { owned } \\
\text { utilities only }\end{array}$ \\
\hline $\begin{array}{l}\text { Oregon - } \\
\text { City of } \\
\text { Ashland } \\
\end{array}$ & $\begin{array}{l}\text { none specified; } \\
\text { Commercial, } \\
\text { Residential } \\
\end{array}$ & Photovoltaics, Wind & $\begin{array}{c}\text { up to } 1,000 \mathrm{kWh} / \text { month purchased at } \\
\text { retail price }\end{array}$ & $\begin{array}{l}\text { Ashland } \\
\text { Electric }\end{array}$ \\
\hline Oregon & $\begin{array}{c}25 \mathrm{~kW} \\
\text { Commercial, Industrial, } \\
\text { Residential }\end{array}$ & $\begin{array}{l}\text { Solar Thermal Electric, Photovoltaics, } \\
\text { Wind, Hydroelectric, Fuel Cells }\end{array}$ & $\begin{array}{l}\text { Purchased at avoided cost or credited to } \\
\text { following month }\end{array}$ & All utilities \\
\hline Pennsylvania & $\begin{array}{c}\text { Varies by utility; } \\
\text { Links to tariffs of } \\
\text { individual utilities are } \\
\text { available on the PUC's } \\
\text { Web site } \\
\text { (http://puc.paonline.co } \\
\text { m/tariffs/ } \\
\text { Electric_Tariffs.htm) }\end{array}$ & $\begin{array}{l}\text { Solar Thermal Electric, Photovoltaics, } \\
\text { Wind, Biomass, Hydroelectric }\end{array}$ & $\begin{array}{l}\text { Granted to utility in most cases; Varies } \\
\text { by utility; } \\
\text { Links to tariffs of individual utilities are } \\
\text { available on the PUC's Web site } \\
\text { (http://puc.paonline.com/tariffs/ } \\
\text { Electric_Tariffs.htm) }\end{array}$ & $\begin{array}{l}\text { All electric } \\
\text { utilities } \\
\text { regulated by } \\
\text { the PUC }\end{array}$ \\
\hline $\begin{array}{l}\text { Texas - } \\
\text { San Antonio } \\
\text { City Public } \\
\text { Service } \\
\end{array}$ & $\begin{array}{c}25 \mathrm{~kW} \\
\text { Commercial, } \\
\text { Residential }\end{array}$ & $\begin{array}{c}\text { Photovoltaics, Landfill Gas, Wind, Biomass, } \\
\text { Hydroelectric, Geothermal Electric, Tidal } \\
\text { Energy, Wave Energy }\end{array}$ & $\begin{array}{c}1.65 \text { cents per kilowatt-hour }(\mathrm{kWh}) \\
\text { during non-summer months and } 2.02 \\
\text { cents per } \mathrm{kWh} \text { from June through } \\
\text { September }\end{array}$ & $\begin{array}{l}\text { San Antonio } \\
\text { City Public } \\
\text { Service }\end{array}$ \\
\hline Texas & $\begin{array}{c}50 \mathrm{~kW} \\
\text { Commercial, Industrial, } \\
\text { Residential }\end{array}$ & $\begin{array}{c}\text { Solar Thermal Electric, Photovoltaics, } \\
\text { Landfill Gas, Wind, Biomass, } \\
\text { Hydroelectric, Geothermal Electric, Fuel } \\
\text { Cells, Tidal Energy, Wave Energy, } \\
\text { Microturbines }\end{array}$ & Purchase not to exceed avoided cost & $\begin{array}{l}\text { Applies to } \\
\text { all PTB } \\
\text { REPs, } \\
\text { TDUs, and } \\
\text { integrated }\end{array}$ \\
\hline
\end{tabular}




\begin{tabular}{|c|c|c|c|c|}
\hline State & $\begin{array}{l}\text { System Size Limit/ } \\
\text { Customer Classes }\end{array}$ & Eligible Technologies & Treatment of Net Excess Generation & $\begin{array}{l}\text { Utilities } \\
\text { Involved }\end{array}$ \\
\hline & & & & $\begin{array}{c}\text { IOUs; does } \\
\text { not include } \\
\text { municipals, } \\
\text { river } \\
\text { authorities, } \\
\text { co-ops }\end{array}$ \\
\hline Utah & $\begin{array}{c}25 \mathrm{~kW} \\
\text { Commercial, Industrial, } \\
\text { Residential }\end{array}$ & $\begin{array}{l}\text { Solar Thermal Electric, Photovoltaics, } \\
\text { Wind, Hydroelectric, Fuel Cells }\end{array}$ & $\begin{array}{l}\text { Credited to the following month, then } \\
\text { granted to the utility at end of annual } \\
\text { period with no compensation }\end{array}$ & All utilities \\
\hline Vermont & $\begin{array}{l}150 \mathrm{~kW} \text { for farm } \\
\text { systems; } 15 \mathrm{~kW} \text { for } \\
\text { Commercial, } \\
\text { Residential }\end{array}$ & Photovoltaics, Wind, Biomass, Fuel Cells & $\begin{array}{l}\text { Credited to the following month, then } \\
\text { granted to the utility at end of annual } \\
\text { period with no compensation }\end{array}$ & All utilities \\
\hline Virginia & $\begin{array}{l}10 \mathrm{~kW} \text { residential, } 500 \\
\mathrm{~kW} \text { commercial }\end{array}$ & $\begin{array}{c}\text { Solar Thermal Electric, Photovoltaics, } \\
\text { Wind, Hydroelectric }\end{array}$ & $\begin{array}{l}\text { Credited to the following month, then } \\
\text { either granted to utility annually or } \\
\text { credited to following month }\end{array}$ & All utilities \\
\hline Washington & $\begin{array}{c}25 \mathrm{~kW} \\
\text { Commercial, Industrial, } \\
\text { Residential } \\
\end{array}$ & $\begin{array}{l}\text { Solar Thermal Electric, Photovoltaics, } \\
\text { Wind, Hydroelectric, Fuel Cells }\end{array}$ & $\begin{array}{l}\text { Credited to the following month, then } \\
\text { granted to the utility at end of annual } \\
\text { period with no compensation }\end{array}$ & All utilities \\
\hline $\begin{array}{l}\text { Washington - } \\
\text { Grays Harbor } \\
\text { PUD }\end{array}$ & $\begin{array}{c}25 \mathrm{~kW} \\
\text { Commercial, Industrial, } \\
\text { Residential }\end{array}$ & $\begin{array}{l}\text { Solar Thermal Electric, Photovoltaics, } \\
\text { Wind, Hydroelectric, Fuel Cells }\end{array}$ & $\begin{array}{l}\text { Purchased by the utility at year-end for } \\
50 \% \text { of the retail rate }\end{array}$ & $\begin{array}{l}\text { Grays } \\
\text { Harbor } \\
\text { PUD }\end{array}$ \\
\hline Wyoming & $\begin{array}{c}25 \mathrm{~kW} \\
\text { Commercial, Industrial, } \\
\text { Residential }\end{array}$ & $\begin{array}{c}\text { Photovoltaics, Wind, Biomass, } \\
\text { Hydroelectric }\end{array}$ & $\begin{array}{l}\text { Credited to the following month, then } \\
\text { purchased at avoided cost by the utility } \\
\text { at the end of the annual period }\end{array}$ & $\begin{array}{l}\text { All IOUs \& } \\
\text { Co-ops }\end{array}$ \\
\hline
\end{tabular}




\subsection{Generator Size and Efficiency}

An elementary model of CHP energy consumption was formulated to assess effects of generator size and efficiency on the operating costs and energy consumption of a CHP system. The energy consumption and operating costs were compared to those of a conventional HVAC system with power provided from the grid. The analysis made the following assumptions:

1) The CHP total energy efficiency is $80 \%$. Therefore the heat recovery percentage is $80 \%$ minus the electric efficiency percentage.

2) An $80 \%$ efficient supplementary heating system is used to supplement the CHP heat output when this is inadequate to meet the heat load.

3) The electric grid primary (source) efficiency is $33 \%$.

4) The efficiency of the baseline conventional heating system is $90 \%$ (e.g., a condensing gas furnace).

5) The cost of gas fuel is $\$ 10.00 / \mathrm{MMBtu}$. The cost of electricity is $\$ 0.085 / \mathrm{kWh}=$ $\$ 25.00 /$ MMBtu. This is a "Spark Spread" of \$15.00/MMBtu, or a "Spark Ratio" of 2.5.

6) The annual electricity consumption is $12,000 \mathrm{kWh}$, which is close to the national average for newly constructed single family homes in Table 10 .

7) The annual heating load is $6,000,12,000$, or $24,000 \mathrm{kWh}(20.5,41$, or 82 million Btu). This covers the range of thermal loads and thermal/electric load ratios in the different climate regions of Table 10.

8) The CHP system follows the thermal load. Excess generated electricity is exported to the grid.

9) The electric utility permits "net metering" of electricity. However, the annual net metering is limited to zero; that is, the CHP system cannot be a net seller of electricity on an annual basis.

10) In each case, the CHP system is sized for 2,000 hours of operation per year. That is, for an annual heating load of $24,000 \mathrm{kWh}$, the CHP heat output would be $12 \mathrm{~kW}$, or about 41,000 Btu/hr.

Table 10 shows the energy consumption by end use for single family new construction homes for the entire nation and by climate region calculated from EIA data for 2001. The total energy consumed annually for space and water heating ranges from $10,527 \mathrm{kWh}$ to $26,861 \mathrm{kWh}$, with a national average of $19,299 \mathrm{kWh}$. Electricity consumption ranges from $10,713 \mathrm{kWh}$ to 15,891 $\mathrm{kWh}$, with a national average of $12,529 \mathrm{kWh}$. The ratio of the thermal to electrical energy consumption ranges from 2.48 in the coldest region to 0.66 in the warmest, with a national average of 1.54. If we assume an average heating efficiency of $80 \%$, the ratio of the heating load to the electricity consumption ranges from 0.53 to 1.98 , with a national average of 1.23 . The corresponding $12 / 24 / 7$ average electrical loads range from $1.22 \mathrm{~kW}$ to $1.81 \mathrm{~kW}$, with a national average of $1.43 \mathrm{~kW}$. 
Table 10. Calculated Energy Consumption for Single Family New Construction Homes by Climate Region

\begin{tabular}{|l|c|c|c|c|c|c|}
\hline Heating Degree Days & TOTAL & $\mathbf{7 , 0 0 0}$ & $\begin{array}{c}\mathbf{5 5 0 0}- \\
\mathbf{7 0 0 0}\end{array}$ & $\begin{array}{c}\mathbf{4 0 0 0}- \\
\mathbf{5 4 9 9}\end{array}$ & $\mathbf{< 4 , 0 0 0}$ & $\begin{array}{c}\mathbf{2 , 0 0 0} \\
\mathbf{C D D} \text { and } \\
<\mathbf{4 , 0 0 0} \\
\text { HDD }\end{array}$ \\
\hline kWh per household where the end use is & & & & & & \\
\hline Space Heating & 13,379 & 20,428 & 20,068 & 15,000 & 7,178 & 5,635 \\
\hline Water Heating & 5,920 & 6,138 & 6,793 & 5,983 & 5,702 & 4,892 \\
\hline Total Space \& Water Heating & 19,299 & 26,567 & 26,861 & 20,982 & 12,880 & 10,527 \\
\hline Electric Air Conditioning & 2,321 & 896 & 1,059 & 1,670 & 2,362 & 4,479 \\
\hline Refrigerators & 1,465 & 1,270 & 1,335 & 1,400 & 1,400 & 1,889 \\
\hline Other Appliances and Lighting & 8,742 & 8,547 & 8,937 & 8,352 & 8,040 & 9,523 \\
\hline Total Electric & 12,529 & 10,713 & 11,331 & 11,422 & 11,802 & 15,891 \\
\hline & & & & & & \\
\hline Space \& Water Heating/Elec & 1.54 & 2.48 & 2.37 & 1.84 & 1.09 & 0.66 \\
\hline $\mathbf{0 . 8}$ * Space \& Water Heating/Elec & 1.23 & 1.98 & 1.90 & 1.47 & 0.87 & 0.53 \\
\hline Average Electrical Load - kW & 1.43 & 1.22 & 1.29 & 1.30 & 1.35 & 1.81 \\
\hline
\end{tabular}

The CHP energy consumption and costs were modeled versus electric generating efficiency as a function of thermal loads typical of warmer, temperate, and colder climates. The 2000 hour sizing of the CHP systems requires average thermal outputs of $3 \mathrm{~kW}, 6 \mathrm{~kW}$, or $12 \mathrm{~kW}$ for 6000 $\mathrm{kWh}, 12,000 \mathrm{kWh}$, and 24,000 $\mathrm{kWh}$ annual heating loads, respectively.

Figure 2 shows the required generating capacity versus electric generating efficiency for the three heating loads. As the efficiency increases, the ratio of heat output to electric power is reduced, requiring a larger generator to supply a given heating load. A $20 \%$ efficient generator would require a $4 \mathrm{~kW}$ electric generator capacity to supply $12 \mathrm{~kW}$ of thermal output to handle a $24,000 \mathrm{kWh}$ annual heating load while operating for 2000 hours per year.

For the case of a 24,000 kWh heating load, the power output reaches a maximum of $6 \mathrm{~kW}$ at generating efficiencies above $27 \%$. This is because at $27 \%$ efficiency, $24,000 \mathrm{kWh}$ of heat output is achieved with $12,000 \mathrm{kWh}$ of electric generation, which is the limit for zero net metering. For higher heat loads, this limit would be reached at lower generating efficiencies. 


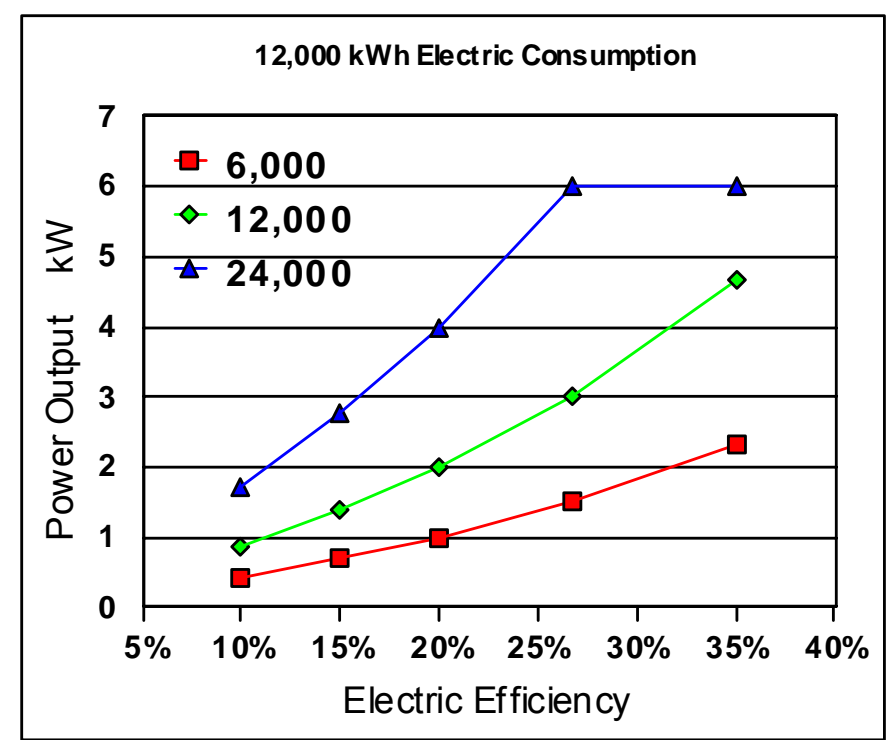

Figure 2. Generator capacity versus generating efficiency as a function of annual heating loads

Figures 3 and 4 show the annual cost and energy savings versus a baseline conventional heating system with power provided from the grid. At the assumed energy prices, the savings are about nil for a generating efficiency of $10 \%$. At $20 \%$ efficiency and an annual heating load of 24,000 $\mathrm{kWh}$, the annual savings are about $\$ 230$. The annual savings rise as the efficiency increases, up to a maximum of $\$ 400$ for a heat load of $24,000 \mathrm{kWh}$. The primary energy savings track the cost savings. A $10 \%$ efficient CHP system produces negligible primary energy savings. At $20 \%$ efficiency and a heat load of 24,000 $\mathrm{kWh}$, the primary energy savings are about $11,000 \mathrm{kWh}$, or about $17 \%$ of the baseline primary energy consumption of $63,000 \mathrm{kWh}$ ( 215 million Btu).

Maximum primary energy savings at a heat load of 24,000 $\mathrm{kWh}$ are about $18,000 \mathrm{kWh}$, or about $29 \%$ of the baseline primary energy consumption. 


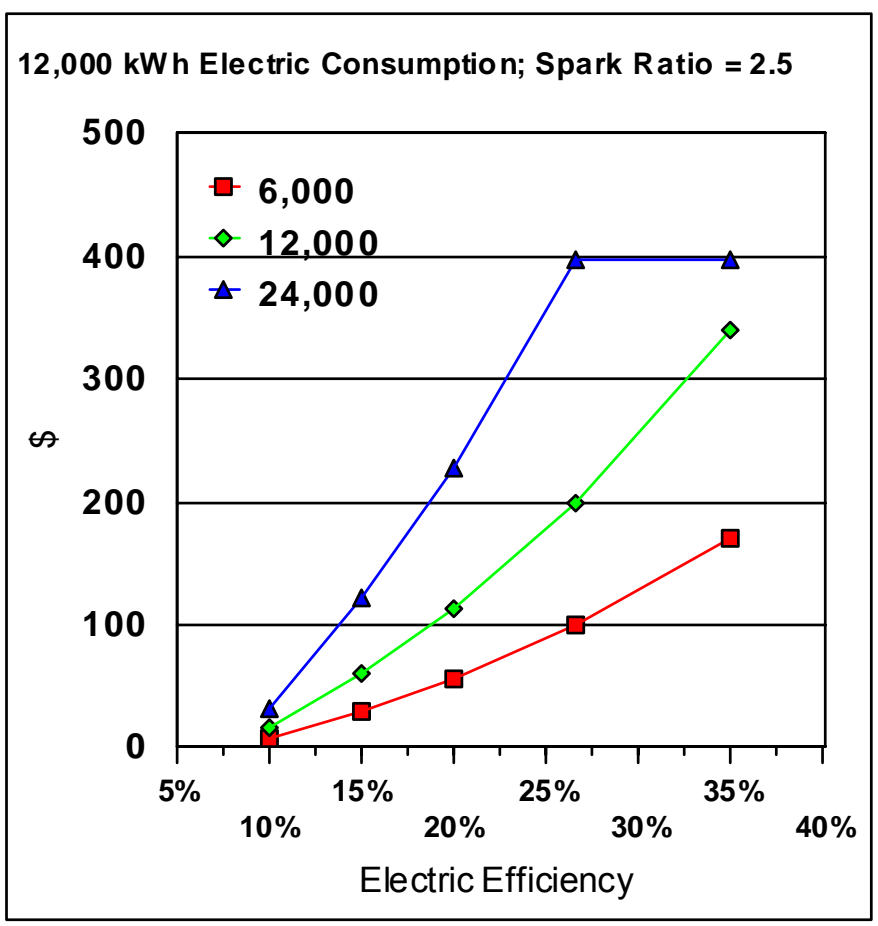

Figure 3. Annual cost savings versus baseline system as a function of annual heating loads

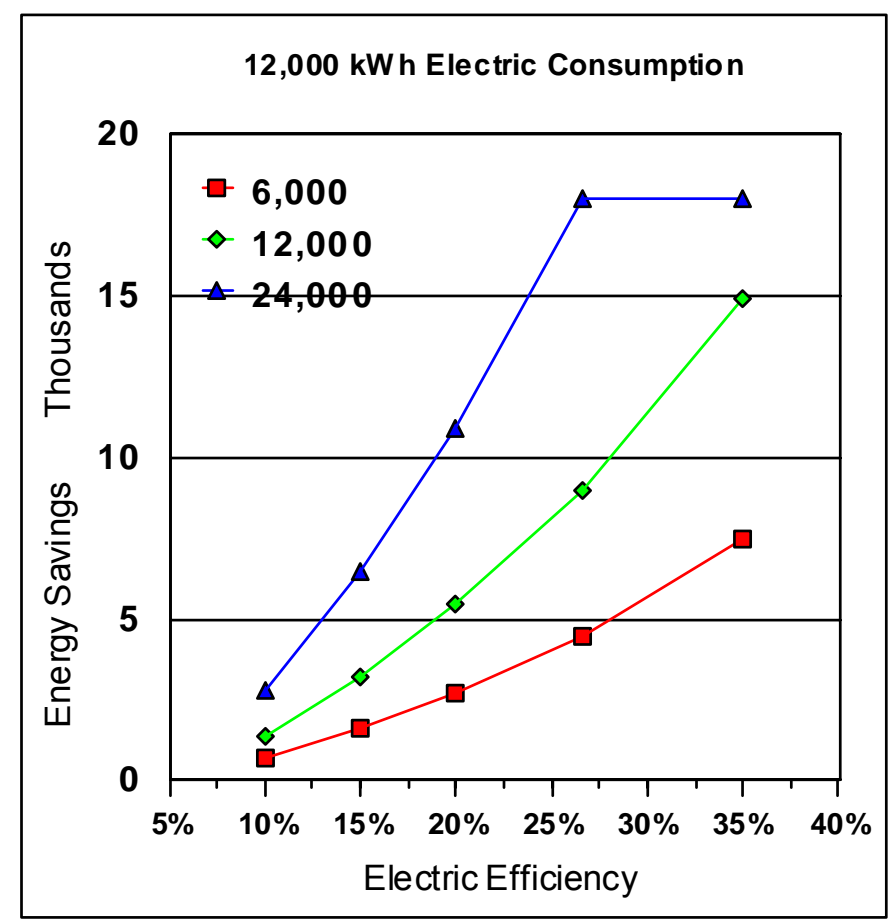

Figure 4. Annual primary energy savings versus baseline system as a function of annual heating loads 
Figure 5 shows the incremental CHP purchase price that would be required to result in a 3 -year payback period. The allowable price per $\mathrm{kW}$ of generator output is the same for all of the annual heating loads, except for the case of the $24,000 \mathrm{kWh}$ heat load above $27 \%$ efficiency. Here, the allowable price per $\mathrm{kW}$ is a constant since its energy savings are capped at the $27 \%$ efficiency level. The allowable incremental CHP price increases as the generating efficiency rises, but at a diminishing rate. Moreover, the allowable prices are disappointingly low. This indicates that it may be unrealistic to expect to achieve short paybacks at current energy price ratios.

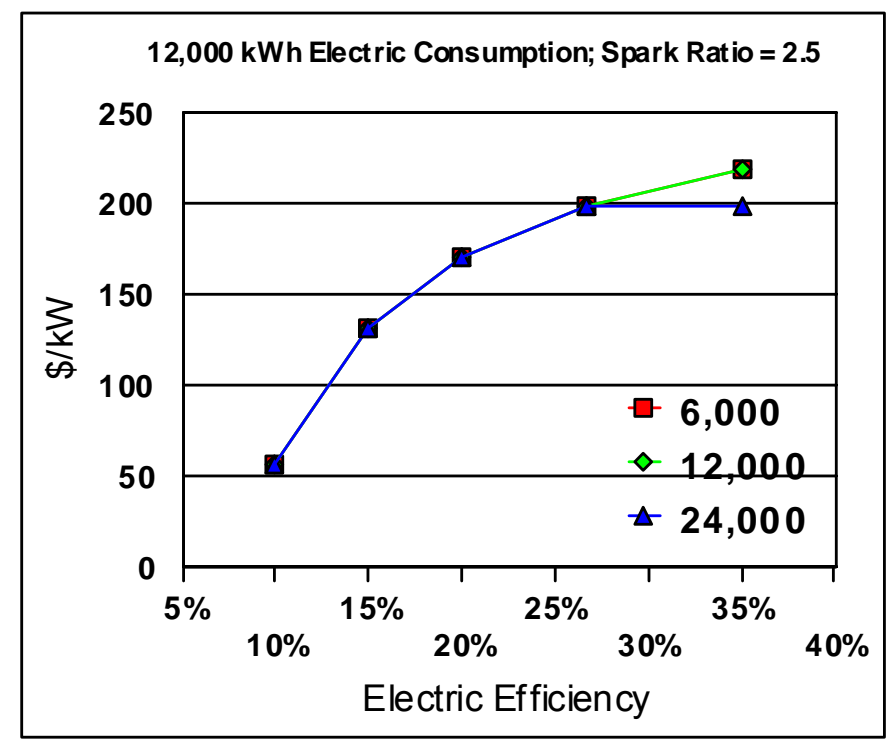

Figure 5. Incremental CHP cost required for a three-year payback

This model assumed that net metering was limited to zero on an annual basis. If net metering must be non-negative on a shorter time-frame, such as monthly, the maximum CHP heat load will be reduced substantially. This is illustrated by Figure 6, which assumes that the annual heating load occurs within a six-month period during which the net metering is limited to zero. Here, the maximum cost savings (and energy savings) are capped at much lower levels and than in Figure 3. The maximum savings are highest at the lower heat loads. This is because of the greater use of supplementary heating at the higher heat loads, which is assumed to be at a lower efficiency than the baseline heating system in this model. 


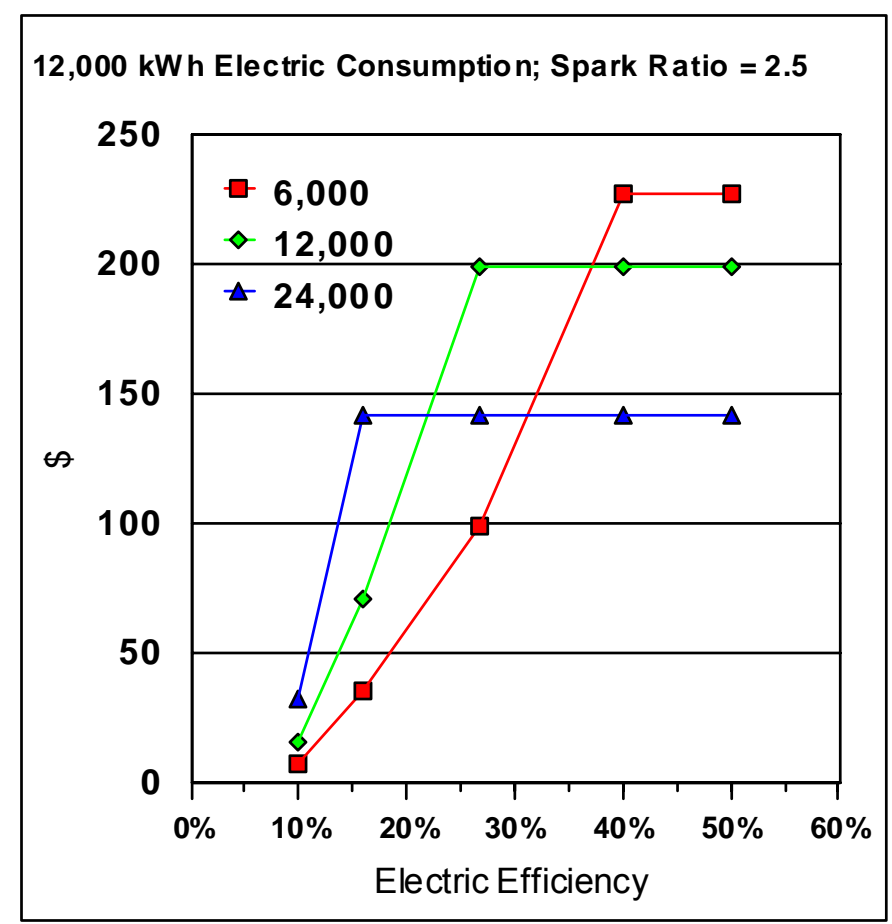

Figure 6. Annual cost savings versus baseline system as a function of annual heating loads assuming that zero net metering applies over a six-month heating season

Although this CHP performance model is highly simplified, it does quantify the essential characteristics of the residential CHP system. It leads to the following general assessments regarding generating efficiency and equipment size:

1) The annual primary energy savings increase with generating efficiency and are proportional to heat load unless capped by zero net metering requirements. Therefore the greatest energy and cost savings will occur in colder regions, unless they are limited by shorter-term zero net metering limits.

2) A 20\%-efficient CHP generator suitable for colder climates should have an electric generating capacity of about $4 \mathrm{~kW}$ in order to limit running time to about 2000 hours annually. Heating loads in warmer climates can be achieved by smaller generators, or by larger generators with much shorter run-times.

3) In view of the modest operating cost savings, it is unrealistic to expect to achieve payback periods approaching 3 years at current energy prices.

A key consideration is that the primary energy savings are more or less proportional to the generating efficiency. If the national goal is to reduce primary energy consumption, it is important to have high CHP electric generation efficiency. However, unless zero net metering restrictions are lifted, the benefits of higher efficiency may not be realized. 


\subsection{Spark Spread and Spark Ratio}

Spark spread is a key economic driver for self-generation technologies. It is the differential between the price of electricity and the price of natural gas expressed on a common energy basis. In this report, we define "Spark Ratio" as the ratio of the electric energy price to natural gas energy price. For a given spark ratio, the spark spread will be proportional to the price of gas. This ratio changes throughout the year in many localities due to seasonal adjustments in fuel pricing and other factors. A minimum spark ratio is required for a given co-generation system to show positive operating savings compared to purchased electricity ${ }^{5}$. For the proposed system, the threshold spark ratio for positive operating savings is about 3 .

The average residential electricity and gas prices for 2001 are shown in Table 11. The average spark ratio among the states was 3.24, and 11 states had spark ratios of 3.0 or higher. By mid2005, as a result of fuel price disruptions, only 4 states: Alaska, California, New York and Vermont had spark ratios of 3.0 or higher, and the average of all states had dropped to 2.21 . In view of such volatility, it is difficult to predict future price ratios with much certainty. Clearly, current price ratios are unfavorable for residential CHP operating economics except in those few areas with high spark ratios. A reversal of the recent trend of spark ratios is needed if the operating economics of CHP systems is to improve.

\footnotetext{
${ }^{5}$ Here we are excluding maintenance expenses from operating costs. This is justified in this context, since in most cases the maintenance cost will be a fixed annual expense, which is independent of the operating hours.
} 
Table 11. Average Residential Energy Prices in 2001. Source DOE Energy Information Administration

\begin{tabular}{|l|c|c|c|}
\hline & \multicolumn{2}{|c|}{$\begin{array}{c}\text { Nominal \$ per Million } \\
\text { BTU }\end{array}$} & \$E/\$NG \\
\hline & Natural Gas & Electricity & $\begin{array}{c}\text { Spark } \\
\text { ratio }\end{array}$ \\
\hline Alaska & 4.19 & 35.51 & 8.47 \\
\hline Michigan & 5.60 & 24.20 & 4.32 \\
\hline New Jersey & 7.41 & 30.00 & 4.05 \\
\hline Vermont & 9.95 & 37.13 & 3.73 \\
\hline New York & 11.37 & 41.22 & 3.63 \\
\hline California & 10.27 & 37.07 & 3.61 \\
\hline New Mexico & 7.52 & 25.61 & 3.41 \\
\hline Maine & 10.48 & 34.16 & 3.26 \\
\hline New & 12.01 & 36.61 & 3.05 \\
\hline Hampshire & 8.76 & 26.60 & 3.04 \\
\hline Nevada & 11.82 & 35.56 & 3.01 \\
\hline Rhode Island & 8.69 & 25.98 & 2.99 \\
\hline Texas & 12.25 & 36.59 & 2.99 \\
\hline Massachusetts & 8.86 & 25.54 & 2.88 \\
\hline Illinois & 8.77 & 25.22 & 2.88 \\
\hline Delaware & 7.10 & 20.16 & 2.84 \\
\hline Montana & 8.87 & 24.65 & 2.78 \\
\hline Iowa & 11.93 & 31.98 & 2.68 \\
\hline Connecticut & 8.69 & 23.14 & 2.66 \\
\hline Wisconsin & 9.28 & 24.54 & 2.64 \\
\hline Ohio & 10.91 & 28.20 & 2.58 \\
\hline Colorado & 8.64 & 22.31 & 2.58 \\
\hline Pennsylvania & 19.76 & 18.97 & 2.56 \\
\hline Minnesota & 21.74 & 2.54 \\
\hline Utah & & \\
\hline North Dakota & & & \\
\hline South Dakota & 8.61 & & \\
\hline
\end{tabular}

\begin{tabular}{|c|c|c|c|}
\hline & \multicolumn{2}{|c|}{$\begin{array}{c}\text { Nominal \$ per Million } \\
\text { BTU }\end{array}$} & \multirow{2}{*}{$\begin{array}{c}\text { \$E/\$NG } \\
\begin{array}{c}\text { Spark } \\
\text { ratio }\end{array}\end{array}$} \\
\hline & Natural Gas & Electricity & \\
\hline Wyoming & 8.00 & 19.85 & 2.48 \\
\hline West Virginia & 7.50 & 18.35 & 2.45 \\
\hline Kansas & 9.34 & 22.46 & 2.40 \\
\hline Arizona & 10.45 & 24.32 & 2.33 \\
\hline Arkansas & 9.90 & 22.61 & 2.28 \\
\hline Oklahoma & 9.33 & 21.30 & 2.28 \\
\hline Louisiana & 10.23 & 23.21 & 2.27 \\
\hline Nebraska & 8.57 & 19.06 & 2.22 \\
\hline Georgia & 10.23 & 22.64 & 2.21 \\
\hline Hawaii & 21.77 & 47.88 & 2.20 \\
\hline Indiana & 9.34 & 20.29 & 2.17 \\
\hline Mississippi & 10.10 & 21.61 & 2.14 \\
\hline Idaho & 8.33 & 17.60 & 2.11 \\
\hline $\begin{array}{l}\text { North } \\
\text { Carolina }\end{array}$ & 11.84 & 23.79 & 2.01 \\
\hline Maryland & 11.24 & 22.58 & 2.01 \\
\hline Virginia & 11.52 & 22.85 & 1.98 \\
\hline Missouri & 10.40 & 20.53 & 1.97 \\
\hline Oregon & 9.43 & 18.42 & 1.95 \\
\hline $\begin{array}{l}\text { South } \\
\text { Carolina }\end{array}$ & 11.65 & 22.53 & 1.93 \\
\hline Tennessee & 9.80 & 18.53 & 1.89 \\
\hline $\mathrm{DC}$ & 12.33 & 22.95 & 1.86 \\
\hline Kentucky & 9.20 & 16.37 & 1.78 \\
\hline Washington & 9.46 & 16.70 & 1.77 \\
\hline Alabama & 11.68 & 20.56 & 1.76 \\
\hline Florida & 14.78 & 25.19 & 1.70 \\
\hline Average & 9.06 & 28.24 & 3.24 \\
\hline
\end{tabular}

\subsection{Market Size}

It is difficult to project the number of new homes per year that are viable candidates for microCHP systems, since this technology is so new and the market is in its infancy. Moreover, the market will depend on future events and trends that are difficult to predict. Accordingly, there will be different market size predictions for different economic and regulatory assumptions. Considering that the price of the CHP system will be significantly greater than that of a conventional heating/cooling system, and that the addition of an electric power generator will be a discretionary purchase, it is likely that the majority of buyers of residential CHP systems will 
be more affluent home buyers who perceive a significant value to the security and reliability provided by its ability to operate independent of the grid during power outages.

Scenario A - Current Net Metering. This scenario assumes that significant sales will occur only in those locales that currently allow net-metering. If current net-metering regulations remain in effect, we can project how many homes will be built in the nine states that currently permit netmetering for cogeneration equipment. Table 5 above contains an estimate of new home construction in all of the states and Table 9 lists a summary of the net-metering regulations in the nine states that permit net-metering with cogeneration systems. Combining the two tables, the total new home construction in the nine states during 2003 amounted to 159,000 homes. Since the predominant purchasers of micro-CHP systems are mostly likely to be more affluent than the norm, they are much more likely to own larger-than-average houses, typically on the order of 2,500 sq-ft or larger. We know from Table 6 that the median size new home in the regions of interest is about 2,200 square feet. Thus about half of the new homes being built are larger than 2,200 square feet, and these are the target homes. This reduces the number of candidate homes to 79,500 .

Scenario B - Current Net Metering and Favorable Spark ratio. If we focus just on those six states that have a cogeneration net-metering program and that have a (2001) spark ratio of 3.0 or higher, the total number of new homes constructed in 2003 with floor space greater than 2,200 square feet was about 51,000 .

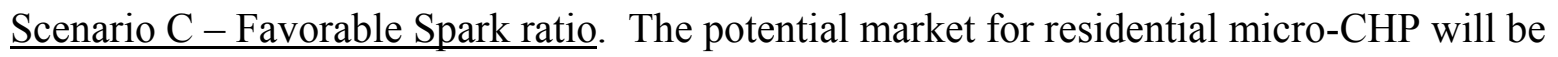
much larger once net-metering regulations are revised to apply to all cogeneration, as is required to take effect by 2008 in the Energy Policy Act of 2005. If all states that had a spark spread of 3.0 or higher in 2001 are included, there were 366,400 homes built in 2003 having a floor area greater than 2,000 square feet. If a favorable gas/electric energy price ratio were to exist throughout the country, as through market forces or as a result of government policy, then the potential market of larger homes would increase to about 750,000 on this basis.

Figure 1 shows the annual home generator production in 2003, with an estimate of 262,364 units produced in the same size range as the micro-CHP system generator. This indicates a significant interest on the part of homeowners to safeguard against grid failures and nuisance blackouts. It also suggests that the market for self-generated electric power is smaller than the number of new homes built, either of average or larger than average size. Consequently, except under a much more favorable energy price scenario, the market for residential micro-CHP is unlikely to exceed the size of today's home generator market, or about 250,000 units.

In summary, we estimate that the potential annual market for the proposed residential microCHP system is in range of about 50,000 to 250,000 units, depending upon future energy price trends and regulations. 


\subsection{Continuous Backup Power}

The proposed micro-CHP system is founded upon the concept of "Continuous Backup Power". Homeowners are familiar with portable generators and with residential standby generators that are used to provide short-term backup power in the event of a failure of the electrical grid. Backup generators are a step above portable generators, and are equipped with transfer switches that prevent simultaneous operation with the grid. Backup generators still employ relatively inexpensive light-duty engines that are intended to operate for short periods only. Indeed, the experience in recent weather catastrophes (e.g., 2005 hurricanes Katrina and Rita) has shown that portable generators and many standby generators were able to operate only for a few days

In contrast to standby generators, primary power generators are designed to operate either islanded or in parallel with the grid on a continuous basis. The residential CHP systems that are gaining popularity in Europe and Asia employ small primary power generators that operate in parallel with the grid. Commercial and industrial primary power generators utilize heavy-duty industrial engines or turbines that are generally larger than the $8-12 \mathrm{~kW}$ capacity of residential standby generators, and which cost considerably more. Few grid-parallel applications employ primary power generators for standby needs. Fewer still use primary power generators in the U.S. for continuous power generation, as the financial incentive is relatively small and is generally of little interest to those who can afford the price of a primary power generator. Yet residential CHP systems require a prime-mover in the class of a primary power generator if the generator is to operate for a significant time in a CHP mode so that significant amount of residential energy consumption can be avoided.

If residential CHP is to appeal to homeowners who are primarily concerned with security, they must be convinced of the benefits of a backup power system employing a primary-power generator versus a less expensive standby generator.

The solution is Continuous Backup, which is a hybrid of primary and standby generation. It is designed to operate continuously in parallel with the grid or islanded from the grid. Moreover, in the grid-parallel mode, it will automatically disconnect from the grid in the event of a grid failure and will re-connect after grid power has been restored. The continuous backup system does not require frequent maintenance and is not destined to fail after a few hundred hours of continuous operation. Thus, Continuous Backup provides the homeowner with the best of backup and primary power capability.

The continuous backup capability is a requirement for the micro-CHP system to provide a fullyintegrated, factory-engineered source for the heating, cooling, domestic hot-water, ventilation and dehumidification needs of the residence, in addition to providing the security of an independent source of electrical power for extended periods of operation - not just for short-term emergencies. This continuous load capability puts it in a superior class to ordinary backup power systems and justifies a cost premium. With its higher purchase price justified on the basis of its long-term security features, the homeowner can afford to take advantage of its operating cost savings by operating it on a continuous basis, thereby producing the energy cost savings afforded by CHP operation. 


\subsection{Competing Technologies}

As residential heating/cooling micro-CHP is a relatively new technology, there is little, if any, established competition. The more established technology is heating-only CHP, which is actively marketed in Europe and supported by government incentives. The two most prevalent residential CHP systems are based on internal-combustion (IC) gas engines and externalcombustion Stirling engines. These are being marketed mainly by established boiler manufacturers, and are viewed primarily as heating boilers with electricity production as a byproduct. The electric power output of most of the European systems is considerably lower than the proposed system, typically about $1 \mathrm{kWe}$, although some are larger, including the present Ecopower system. These systems are capable of overall energy efficiencies (thermal plus electric) of about $80 \%$ of higher heating value (HHV). IC-engine based systems achieve about $20 \%$ electric efficiency, while the Stirling efficiency is considerably lower, at about 10\% - 13\%. Honda has recently announced a small $(<1 \mathrm{kWe})$ residential IC-engine based CHP system. While the smaller systems are generally less expensive, similarly sized CHP systems are priced comparably to the Ecopower.

Other prime-mover technologies that are applicable to residential CHP include Rankine cycle engines and fuel cells. Rankine-cycle engines can be either positive-displacement (reciprocating, scroll, etc.) or turbine-based, and can use water-based or organic working fluids. While small water-based systems are capable of higher electrical efficiencies than organic types, in small sizes they are only practical as positive-displacement devices. Rankine systems tend to be more complex than ICs or Stirlings, and the practical limit to the efficiency of small Rankine engines is about $12 \%-15 \%$.

Fuel cells are capable of significantly higher electrical efficiencies - in the range of 30\% - 40\% in the sizes of interest. There is a high level of R\&D activity to bring a number of competing fuel-cell technologies to market. The main obstacle to commercialization of this technology is its high cost, currently in the range of $\$ 3,000-\$ 5,000 / \mathrm{kWe}$. This hurdle will be the most difficult to overcome in the small sizes required for residential applications.

The IC-engine based Ecopower CHP system was selected for this application because of its high electrical efficiency (over 20\%) and because it is based on a well-established and mature internal combustion engine technology. Moreover, unlike other IC-based CHP systems that utilize automotive or industrial engines, the Marathon engine has been developed specifically as a highendurance $(40,000 \mathrm{hr})$, low-maintenance engine for residential use. As such, this system is believed to be well suited for the residential micro-CHP heating/cooling market.

A similar $6 \mathrm{~kW}$ IC-engine based cogeneration system has been sold in Japan by Aisin Seiki of Japan, and was recently introduced in the US. This system uses a 3-cylinder vertical shaft engine driving a permanent magnet generator and inverter that is paralleled to the grid. It does not have stand-alone or backup capability. About 400 of these have been sold in Japan as co-generation units with the aid of financial incentives provided by the gas utility. 


\subsection{Potential Growth}

Currently the market for the Ecopower micro-CHP system is limited to special interest and high co-generation commercial applications. With islanding capability, applications will be extended to off-grid installations that can take advantage of the CHP capability. The potential for growth of micro-CHP from novelty to the mass market requires it to meet the needs of the larger gridconnected residential market. This will depend upon 5 basic conditions being met:

Power Conversion Electronics for both grid-parallel and standalone islanding. This applies to the power electronics in the micro-CHP product that allow: The power generated by the enginegenerator to be fed back to the utility; to be supplied to the household load together with power from the utility, or to supply power in a standalone mode without having the grid present. This capability will satisfy the needs of the grid-connected customer who is seeking the security of continuous backup power. It will allow remote areas that lack grid service to be connected at a later date.

Pre-engineered Solutions sized and configured for the range of capacities and housing applications, using installer skills that may not presently exist today at the installer level.

Net Metering. This means that wherever a micro-CHP system is installed, that the electric utility will allow the homeowner to sell back unused power to the utility via the existing grid at its same selling price.

Favorable Energy Prices. In order for co-generated energy to be widely used for household energy needs, instead of just for emergency use, its total energy cost (total cost of fuel plus (net) metered electricity plus operation and maintenance) must be less than that of the non-CHP alternatives. In general, this will require a spark ratio of 3.0 or higher.

Competitive Price. Finally the incremental installed cost for the micro-CHP system should be in the $\$ 8,000$ - $\$ 12,000$ range in order to compare favorably with the cost of a conventional standby generator. At these price levels, the higher energy efficiency, lower operating costs, and greater security of continuous backup power cannot be ignored by the discerning homeowner in contrast to the currently existing technology.

\subsection{Market Assessment Conclusions}

The market size analysis indicates that the number of homes that currently are candidates for this system is on the order of 50,000 - 80,000 per year based on new construction statistics and current economic and regulatory factors. Energy prices and net-metering regulations are in flux. If all fifty states were to adopt net-metering regulations similar to those in the nine states that apply net-metering to co-generation, and if gas/electric price ratios become more favorable than at present, then the market size would be up to ten times higher than the previous estimate. If the present design captures ten percent of the market in new home construction, then the potential sales could range from about 5,000 units annually to as many as 75,000 


\section{Screening Analysis}

A screening analysis was performed to estimate micro-CHP energy consumption and cost in various parts of the country, using the DOE-2 building simulation program. The detailed DOE-2 building load simulation results and discussion are given in Section 5 later in this report. This section describes the energy consumption of the micro-CHP systems and compares it to two baseline systems.

The screening analysis evaluated the value of the energy and cost saving features of candidate micro-CHP systems in various parts of the country. The DOE-2 building load simulation model was applied to similar single-family homes in 13 cities with the following four energy systems: (1) baseline all-electric non-CHP HVAC; (2) baseline gas non-CHP HVAC; (3) CHP with gas-fired supplemental heating; and (4) CHP with electric supplemental heating.

The details of the baseline and CHP systems are described in Table 12. All of the systems used high-efficiency 14 SEER electric air-conditioners and operated with $200 \mathrm{cfm}$ positive ventilation systems. The baseline electric system used an electric water heater and a high-efficiency electric heat pump. The baseline gas system used a gas water heater and high-efficiency gas furnace. Space and water heating by the CHP systems was obtained from co-generated heat. Any supplemental heat input required above the capacity of the CHP system was obtained from an $80 \%$ efficient gas-fired water heater in the gas CHP system, and from a $98 \%$ efficient electric water heater in the case of the electric CHP system. The baseline systems included dehumidification by the air-conditioning system, while the CHP systems used desiccant dehumidifiers that were regenerated by CHP heat.

Table 12. Baseline and Micro-CHP systems Used for Energy Consumption Analysis

\begin{tabular}{|c|c|c|c|c|}
\hline & $\begin{array}{c}\text { Baseline A } \\
\text { Gas/Electric }\end{array}$ & $\begin{array}{l}\text { Baseline B } \\
\text { All Electric }\end{array}$ & $\begin{array}{c}\text { Micro CHP } \\
\text { Gas Supplemental }\end{array}$ & $\begin{array}{c}\text { Micro CHP } \\
\text { Electric } \\
\text { Supplemental }\end{array}$ \\
\hline Space Heating & $\begin{array}{l}80,000 \mathrm{Btu} / \mathrm{hr} 92 \% \\
\text { efficient gas furnace }\end{array}$ & $\begin{array}{c}\text { 4-ton } 9.5 \mathrm{Btu} / \mathrm{kWh} \\
\text { Heat Pump }\end{array}$ & $12.5 \mathrm{~kW}$ Jacket Heat & $12.5 \mathrm{~kW}$ Jacket Heat \\
\hline $\begin{array}{l}\text { Supplemental } \\
\text { Heating }\end{array}$ & nor & $9 \mathrm{k}$ & $\begin{array}{c}40 \mathrm{MBH}, 80 \% \text { Water } \\
\text { heater }\end{array}$ & $\begin{array}{c}4.5 \mathrm{~kW} \text { electric } \\
\text { heater }\end{array}$ \\
\hline Space Cooling & 4-ton 14 SEER A/C & 4-ton 14 SEER A/C & 4-ton 14 SEER A/C & 4-ton 4 SEER A/C \\
\hline Dehumidification & 14 SEER A/C & 14 SEER A/C & $\begin{array}{c}\text { Desiccant }+ \text { sensible } \\
\text { wheel cooled by } \\
\text { outdoor air }\end{array}$ & $\begin{array}{c}\text { Desiccant }+ \text { sensible } \\
\text { wheel cooled by } \\
\text { outdoor air }\end{array}$ \\
\hline Ventilation & $\begin{array}{c}200 \mathrm{cfm} \text { mechanical } \\
\text { supply }\end{array}$ & $\begin{array}{l}200 \mathrm{cfm} \text { mechanical } \\
\text { supply }\end{array}$ & $\begin{array}{l}200 \mathrm{cfm} \text { mechanical } \\
\text { supply }\end{array}$ & $\begin{array}{l}200 \mathrm{cfm} \text { mechanical } \\
\text { supply }\end{array}$ \\
\hline $\begin{array}{c}\text { Domestic Hot } \\
\text { Water }\end{array}$ & $\begin{array}{c}50 \text { gal } 80 \% / .63 \mathrm{EF} \text { gas } \\
\text { water heater, } 2 \% \\
\text { standby }\end{array}$ & $\begin{array}{c}50 \text { gal } 0.95 \mathrm{EF} \\
\text { electric, } 0.32 \% \\
\text { standby }\end{array}$ & $\begin{array}{c}\text { Jacket Heat, } 50 \text { gal } 2 \% \\
\text { standby }\end{array}$ & $\begin{array}{c}\text { Jacket Heat, } 50 \text { gal } \\
0.32 \% \text { standby }\end{array}$ \\
\hline
\end{tabular}


The energy consumption and energy costs were modeled by the DOE-2 building energy simulation program. The results are summarized in Table 13. Energy costs are based on local rates in effect in the first quarter of 2005. In Table 13 electrical energy is differentiated as to the electricity "used" on-site versus the electricity "metered" by the utility. These are identical for the baseline systems. Metered electrical energy is lower than that used on-site for the microCHP cases, reflecting the on-site power generation. For Boston, Washington, DC, Chicago, Newark, NJ, Seattle and Denver the micro-CHP system with gas supplemental heating is a net electricity generator.

Table 13. Comparison of Energy Consumption and Cost in 13 Cities

\begin{tabular}{|c|c|c|c|c|c|c|c|c|c|c|c|c|c|c|c|c|c|}
\hline & & \multicolumn{4}{|c|}{ Baseline-A } & \multicolumn{4}{|c|}{ Baseline-B } & \multicolumn{4}{|c|}{ mCHP w Gas } & \multicolumn{4}{|c|}{ mCHP w Elec } \\
\hline & & \multicolumn{2}{|c|}{ Electric } & \multirow{2}{*}{$\begin{array}{c}\text { Gas } \\
\text { Meter }\end{array}$} & \multirow{2}{*}{$\begin{array}{c}\text { Total } \\
\text { Source }\end{array}$} & \multicolumn{2}{|c|}{ Electric } & \multirow{2}{*}{$\begin{array}{c}\text { Gas } \\
\text { Meter }\end{array}$} & \multirow{2}{*}{$\begin{array}{c}\text { Total } \\
\text { Source }\end{array}$} & \multicolumn{2}{|c|}{ Electric } & \multirow{2}{*}{$\begin{array}{c}\text { Gas } \\
\text { Meter }\end{array}$} & \multirow{2}{*}{$\begin{array}{c}\text { Total } \\
\text { Source }\end{array}$} & \multicolumn{2}{|c|}{ Electric } & \multirow{2}{*}{$\begin{array}{c}\text { Gas } \\
\text { Meter }\end{array}$} & \multirow{2}{*}{$\begin{array}{c}\text { Total } \\
\text { Source }\end{array}$} \\
\hline & & Used & Meter & & & Used & Meter & & & Used & Meter & & & Used & Meter & & \\
\hline & & $\mathrm{kWh}$ & kWh & MBTU & MBTU & $\mathrm{kWh}$ & $\mathrm{kWh}$ & MBTU & MBTU & $\mathrm{kWh}$ & $\mathrm{kWh}$ & MBTU & MBTU & $\mathrm{kWh}$ & $\mathrm{kWh}$ & MBTU & MBTU \\
\hline \multirow{2}{*}{ Miami } & Energy & 22,415 & 22,415 & 35 & 267 & 27,918 & 27,918 & - & 289 & 24,452 & 12,436 & 146 & 300 & 20,920 & 12,889 & 139 & 297 \\
\hline & \begin{tabular}{|l|l} 
Cost \\
\end{tabular} & & $\$ 2,018$ & $\$ 551$ & $\$ 2,569$ & & $\$ 2,518$ & $\$ 0$ & $\$ 2,518$ & & $\$ 1,011$ & $\$ 1,900$ & $\$ 2,911$ & & $\$ 1,155$ & $\$ 1,815$ & $\$ 2,970$ \\
\hline \multirow{2}{*}{ Houston } & Energy & 18,746 & 18,746 & 81 & 274 & 29,672 & 29,672 & - & 307 & 20,187 & 7,199 & 181 & 273 & 22,013 & 9,943 & 158 & 278 \\
\hline & Cost & & $\$ 2,391$ & $\$ 739$ & $\$ 3,130$ & & $\$ 3,607$ & $\$ 0$ & $\$ 3,607$ & & $\$ 982$ & $\$ 1,502$ & $\$ 2,484$ & & $\$ 1,288$ & $\$ 1,330$ & $\$ 2,618$ \\
\hline \multirow{2}{*}{ Boston } & Energy & 12,405 & 12,405 & 232 & 360 & 42,088 & 42,088 & - & 435 & 13,571 & $(2,505)$ & 317 & 294 & 29,945 & 13,831 & 240 & 386 \\
\hline & Cost & & $\$ 1,892$ & $\$ 3,099$ & $\$ 4,991$ & & $\$ 6,235$ & $\$ 0$ & $\$ 6,235$ & & $\$ 77$ & $\$ 4,130$ & $\$ 4,207$ & & $\$ 2,099$ & $\$ 3,216$ & $\$ 5,315$ \\
\hline \multirow{2}{*}{ St Louis } & Energy & 15,121 & 15,121 & 196 & 352 & 42,441 & 42,441 & - & 439 & 16,288 & 1,175 & 284 & 302 & 29,812 & \begin{tabular}{l|}
14,712 \\
\end{tabular} & 221 & 379 \\
\hline & Cost & & $\$ 1,093$ & $\$ 2,083$ & $\$ 3,176$ & & $\$ 2,300$ & $\$ 0$ & $\$ 2,300$ & & $\$ 328$ & $\$ 2,961$ & $\$ 3,289$ & & $\$ 1,011$ & $\$ 2,327$ & $\$ 3,338$ \\
\hline \multirow{2}{*}{ Atlanta } & Energy & 15,046 & 15,046 & 153 & 309 & 31,254 & 31,254 & - & 323 & 16,506 & 4,463 & 195 & 250 & 21,588 & 9,485 & 171 & 278 \\
\hline & Cost & & $\$ 867$ & $\$ 1,531$ & $\$ 2,398$ & & $\$ 1,546$ & $\$ 0$ & $\$ 1,546$ & & $\$ 350$ & $\$ 2,177$ & $\$ 2,527$ & & $\$ 576$ & $\$ 1,939$ & $\$ 2,515$ \\
\hline \multirow{2}{*}{ Memphis } & Energy & 16,402 & 16,402 & 128 & 297 & 32,289 & 32,289 & - & 334 & 18,074 & 5,323 & 200 & 268 & 23,088 & \begin{tabular}{l|}
10,539 \\
\end{tabular} & 172 & 294 \\
\hline & \begin{tabular}{|l} 
Cost \\
\end{tabular} & & $\$ 1,132$ & $\$ 1,398$ & $\$ 2,530$ & & $\$ 2,178$ & $\$ 0$ & $\$ 2,178$ & & $\$ 421$ & $\$ 2,148$ & $\$ 2,569$ & & $\$ 752$ & $\$ 1,858$ & $\$ 2,610$ \\
\hline \multirow{2}{*}{ Wash DC } & Energy & 13,767 & 13,767 & 189 & 332 & 38,573 & 38,573 & - & 399 & 14,766 & (150) & 272 & 275 & 25,910 & 10,878 & 221 & 338 \\
\hline & Cost & & $\$ 1,541$ & $\$ 2,371$ & $\$ 3,912$ & & $\$ 4,078$ & $\$ 0$ & $\$ 4,078$ & & $\$ 96$ & $\$ 3,370$ & $\$ 3,466$ & & $\$ 1,228$ & $\$ 2,766$ & $\$ 3,994$ \\
\hline \multirow[b]{2}{*}{ Chicago } & Energy & 13,358 & 13,358 & 246 & 384 & 47,051 & 47,051 & - & 487 & 14,622 & $(2,013)$ & 334 & 328 & 33,170 & 16,273 & 251 & 423 \\
\hline & \begin{tabular}{|l} 
Cost \\
\end{tabular} & & $\$ 1,128$ & $\$ 2,380$ & $\$ 3,508$ & & $\$ 2,918$ & $\$ 0$ & $\$ 2,918$ & & $\$ 159$ & $\$ 3,146$ & $\$ 3,305$ & & $\$ 1,235$ & $\$ 2,417$ & $\$ 3,652$ \\
\hline \multirow{2}{*}{ Newark NJ } & Energy & 13,305 & 13,305 & 204 & 342 & 39,314 & 39,314 & - & 407 & 14,034 & (797) & 278 & 276 & 27,490 & 12,481 & 221 & 355 \\
\hline & Cost & & $\$ 1,508$ & $\$ 2,259$ & $\$ 3,767$ & & $\$ 4,686$ & $\$ 0$ & $\$ 4,686$ & & $\$ 27$ & $\$ 3,045$ & $\$ 3,072$ & & $\$ 1,434$ & $\$ 2,434$ & $\$ 3,868$ \\
\hline Raleiah NC & Energy & 14,620 & 14,620 & 143 & 294 & 33,011 & 33,011 & - & 341 & 15,903 & 2,786 & 218 & 254 & 22,136 & 9,482 & 181 & 287 \\
\hline Raleigh NC & \begin{tabular}{|l|} 
Cost \\
\end{tabular} & & $\$ 1,173$ & $\$ 2,009$ & $\$ 3,182$ & & $\$ 2,570$ & $\$ 0$ & $\$ 2,570$ & & $\$ 293$ & $\$ 2,993$ & $\$ 3,286$ & & $\$ 781$ & $\$ 2,511$ & $\$ 3,292$ \\
\hline$S$ & Energy & 10,811 & 10,811 & 187 & 299 & 32,389 & 32,389 & - & 335 & 11,616 & $(3,390)$ & 257 & 244 & 16,899 & 1,993 & 228 & 247 \\
\hline s & Cost & & $\$ 555$ & $\$ 1,918$ & $\$ 2,473$ & & $\$ 2,078$ & $\$ 0$ & $\$ 2,078$ & & $\$ 69$ & $\$ 2,606$ & $\$ 2,675$ & & $\$ 69$ & $\$ 2,329$ & $\$ 2,398$ \\
\hline San Fran & Energy & 10,435 & 10,435 & 122 & 230 & 24,846 & 24,846 & - & 257 & 11,181 & 527 & 167 & 172 & 11,966 & 1,721 & 156 & 174 \\
\hline San Francısco & \begin{tabular}{|l|} 
Cost \\
\end{tabular} & & $\$ 1,708$ & $\$ 1,218$ & $\$ 2,926$ & & $\$ 4,802$ & $\$ 0$ & $\$ 4,802$ & & $\$ 106$ & $\$ 1,945$ & $\$ 2,051$ & & $\$ 259$ & $\$ 1,808$ & $\$ 2,067$ \\
\hline $\mathrm{n}_{2}$ & Energy & 13,147 & 13,147 & 223 & 359 & 40,280 & 40,280 & - & 417 & 14,441 & $(1,782)$ & 307 & 301 & 27,619 & 11,307 & 247 & 364 \\
\hline Denver & Cost & & $\$ 1,083$ & $\$ 2,023$ & $\$ 3,106$ & & $\$ 2,420$ & $\$ 0$ & $\$ 2,420$ & & $\$ 80$ & $\$ 2,746$ & $\$ 2,826$ & & $\$ 929$ & $\$ 2,223$ & $\$ 3,152$ \\
\hline
\end{tabular}

Figure 7 shows the energy costs of the four systems in graphical form. The cost savings are most strongly influenced by the local electric-gas spark ratio. The savings are generally highest for the micro-CHP systems with gas supplemental heat relative to the all-electric baselines. The micro-CHP systems with gas supplemental heating achieve positive cost savings versus the gas baselines in Houston, Boston, Washington, DC, Chicago, Newark, San Francisco, and Denver, and versus the all-electric baselines in the same cities except for Chicago and Denver. The micro-CHP systems with electric supplemental heating achieve positive cost savings versus the all-electric baselines in Houston, Boston, Washington, DC, Newark, and San Francisco, but only versus the gas baselines in Houston, Seattle and San Francisco.

Significant annual savings for gas CHP versus the electric baseline are estimated for Houston $(\$ 1,123)$, Boston $(\$ 2,028)$, Newark $(\$ 1,614)$, and San Francisco $(\$ 2,751)$. These are primarily due to a favorable spark ratio, as well as to a significant wintertime heating load. Houston has both a sizable latent cooling load and a moderate heating load, as well as favorable spark ratio. Annual savings in these cities for gas CHP versus the gas baseline are lower, with savings for Houston (\$646), Boston (\$784), Newark (\$695), and San Francisco (\$875). The savings with electric CHP versus gas baseline are generally inferior, with savings only for Houston (\$512) and San Francisco (\$859) due to their lower supplemental heating loads. As a result of adverse 
spark ratios, CHP operating costs are generally unfavorable in Miami, St. Louis, Atlanta, Memphis, Raleigh, and Denver. Additionally, these areas have lower winter-time heating loads (except for Denver), which limits utilization of co-generated heat. Despite a high latent cooling load in Miami, the adverse spark ratio results in higher operating costs for the CHP-powered desiccant cooling.

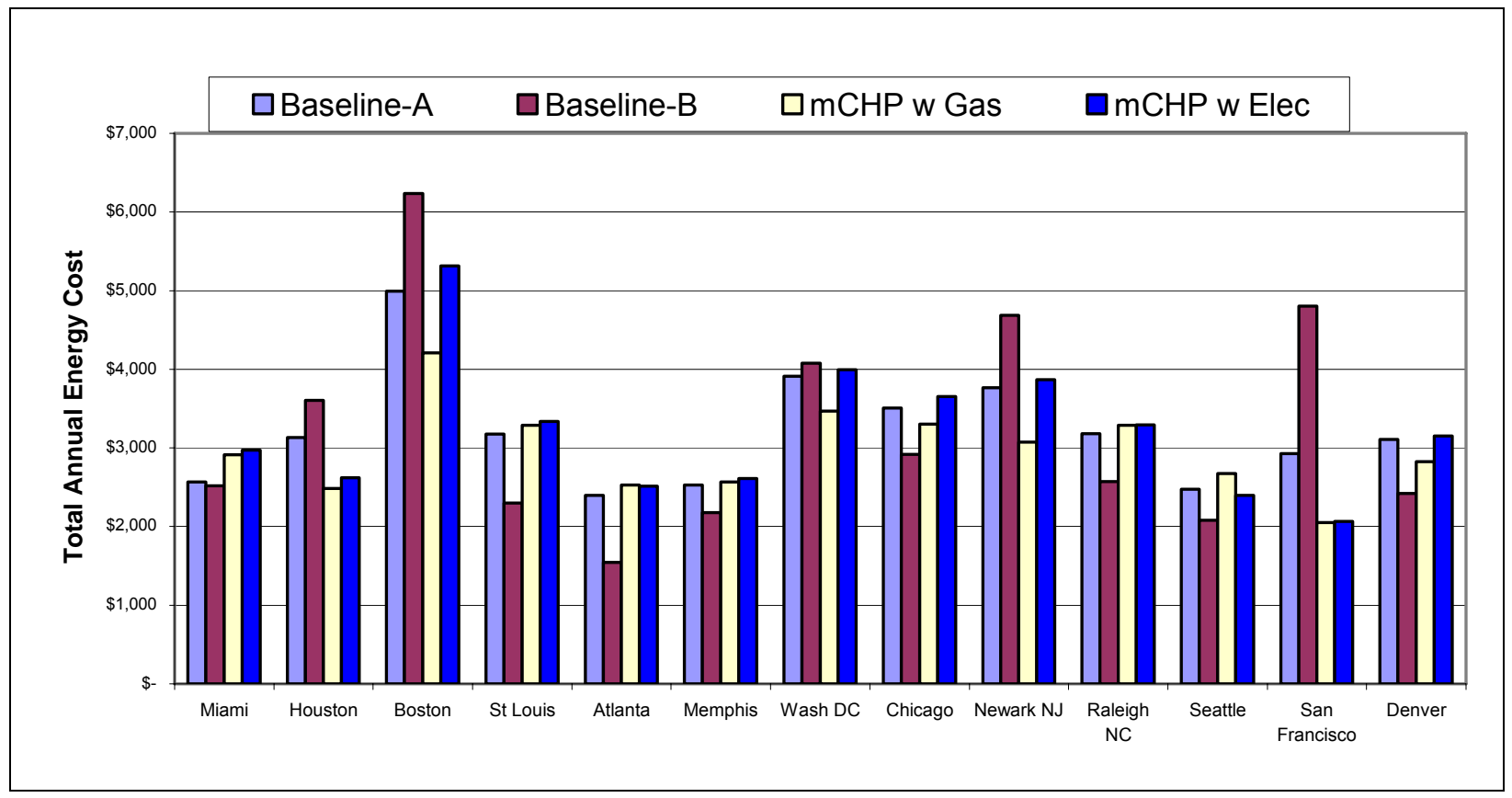

Figure 7. Energy Cost Comparisons of Micro-CHP in 13 Cities

The primary energy savings in the 13 cities are shown in Figure 8. Primary energy is the energy consumed at the source to provide the energy consumed at the site. For this analysis, the primary energy efficiency for electricity was assumed to be $33 \%$, and the primary efficiency for gas was assumed to be $100 \%$. That is, the energy of electricity delivered at the site is only $33 \%$ of the energy required at the power plant to produce that electricity after generation and transmission losses. Gas CHP versus gas baseline (Gas-Gas), electric CHP versus electric baseline (El-El) and gas CHP versus electric baseline (Gas-El) show positive savings in all cities except Miami. Primary energy savings are generally largest for gas CHP compared to the electric baseline, averaging 25\% among the 13 cities. Gas-Gas savings and El-El savings average 13\% and 14\%, respectively. The electric CHP versus gas baseline primary energy savings are generally the lowest or negative. The only cities with significant El-Gas savings are Atlanta, Seattle and San Francisco, where there is little need for supplemental heating. The relatively poorer performance of the electric CHP system in colder locales indicates the significance of supplemental heating on primary energy consumption. 


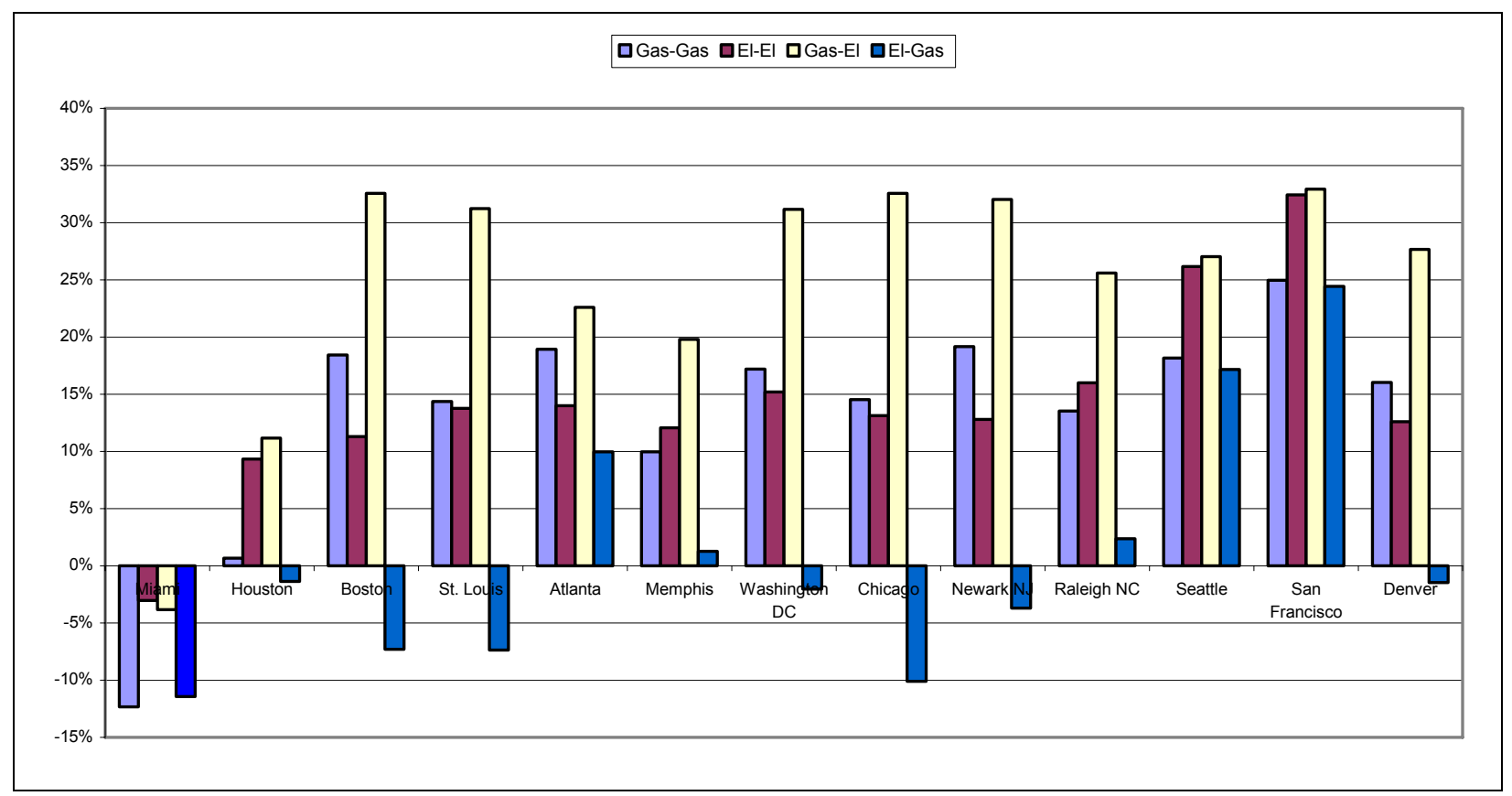

Figure 8. Primary Energy Savings of CHP systems versus Baseline Systems in 13 Cities

These results illustrate the fact that primary energy savings do not always equate with operating cost savings. The locales with positive CHP cost savings are generally in states with above average spark ratios. The 2001 state-wide energy costs and spark ratios across the country are listed in Table 11. Local spark ratios ranged from 8.47 in Alaska to 1.7 in Florida, and the nationwide average was 3.24. By 2004 the nationwide spark ratio was 2.43 , and is estimated to drop to 2.17 for 2005. In 2001, 11 states had spark ratios greater than 3.0; by August 2005 only four states - Alaska, California, New York and Vermont - had statewide averages exceeding 3.0.

The screening analysis established the following conclusions regarding the CHP design features and specifications that would apply in different parts of the country:

- A favorable spark ratio is a prerequisite for positive operational savings from the micro-CHP system

- The largest cost savings appear in applications with significant space heating loads, i.e., in colder climates.

- In cities where a significant supplemental heating requirement exists, the micro-CHP system with gas supplemental heating requires less energy and has lower operating costs than one with electric supplemental heat. CHP with electric supplemental heat may only be suitable for applications with low supplemental heating loads, i.e., in warmer climates.

- Other than for domestic hot water, the only summertime use for co-generated heat is for cooling. Cost savings are significant in humid areas where there is a high latent load, and only if there is a favorable spark ratio. The marginal benefits of a complete desiccant cooling 
system are unlikely to justify the added complexity and cost for Northern cities that have relatively small annual cooling loads.

Three configurations of the basic micro-CHP system are suggested by the foregoing considerations:

- Micro-CHP with desiccant ventilation/dehumidification and electric air-conditioning and supplemental heating for warmer climates with significant latent cooling loads.

- Micro-CHP with electric air-conditioning and supplemental heating for warmer climates without significant latent cooling loads;

- Micro-CHP with electric air conditioning and gas supplemental heating for colder climates. 


\section{Product Characterization}

\subsection{Performance Requirements}

The overall performance requirement is that the proposed micro-CHP system should supply the complete energy needs of the residence as efficiently and cost effectively as practical. The energy loads include electric power, space heating, cooling, and ventilation, and domestic water heating. Furthermore, the micro-CHP system must be capable of operating in parallel with the grid or isolated from it. The market assessment indicates that the primary market, at least initially, will be for larger new homes of 2,500 square feet or more.

For efficient energy utilization, the overall thermal efficiency should be as high a possible. Generally, such systems are capable of overall thermal efficiencies of about $80 \%$ based on the higher heating value of the fuel (or about $90 \%$ based on lower heating value). Furthermore, as demonstrated in Section 2.4, high electric generation efficiency is needed, both to maximize primary energy efficiency and to maximize energy cost savings with the revenue received from the export of surplus electric power to the utility.

Based upon the range of heating and cooling loads determined by the simulation studies described in Section 2.1.5, the target house size sets a minimum requirement of $3-5$ tons $(36,000-60,000) \mathrm{Btu} / \mathrm{hr}$ of air conditioning and a similar level, more or less, of space heating, depending upon climate. For a grid-connected system operating with electric air conditioning, the available cooling load is not dependent on the electrical output of the micro-CHP system. For the CHP system to supply the major portion of the heating load, it must have sufficient thermal output to handle the predominant heating load. While it would be impractical to size the CHP system for the peak heating load, it should be capable of handling the bulk of the seasonal load. Based upon the average and peak spacing heating loads given in Table 8, a CHP thermal output between 30,000 to $50,000 \mathrm{Btu} / \mathrm{hr}(9-15 \mathrm{~kW})$ is appropriate.

In warmer climates, the micro-CHP thermal output may be sufficient for peak wintertime heat loads. In colder climates, the CHP thermal output must be supplemented by an auxiliary heat source. Up to $10 \mathrm{~kW}$ of supplemental heating can be supplied to the micro-CHP system by a 40,000 Btu/hr water heater. For larger design heating loads, a heating boiler may be preferred.

The average non-HVAC electric power consumption of single-family newly-constructed residences in the U.S. in Table 10 is only $1.43 \mathrm{~kW}$. However, for the proposed system to be able to handle at least a sizable portion of the electrical load of the residence in the event of a failure of the electrical grid, a larger capacity is required. Emergency standby generators for singlefamily residence are typically $8-12 \mathrm{~kW}$ or more in order to handle air conditioning together with other coincident loads. Oversizing the generator not only adds to its cost, but it also causes it to operate at a lower load factor, resulting in a lower efficiency. If the goal of the proposed system is energy conservation, the generator should be sized to handle most or all of the continuous power requirements, but without diminishing its efficient performance. Assuming a power generation efficiency of $20 \%$ and an overall efficiency $80 \%$, the heating capacity will be three times the electric capacity. Therefore, a $20 \%$ efficient CHP system capable of $9-15 \mathrm{~kW}$ 
of thermal output would have a generating capacity of $3-5 \mathrm{~kW}$. This provides a reasonable compromise between generating capacity, efficiency, and cost.

The basic performance requirements are summarized in Table 14.

Table 14. CHP Performance Requirements

\begin{tabular}{|l|c|}
\hline Generating Capacity & $3-5 \mathrm{~kW}$ \\
\hline CHP Heat Output & $9-15 \mathrm{~kW}$ \\
\hline Supplemental Heat & As required \\
\hline Cooling Capacity & $3-5$ tons \\
\hline Energy Efficiency & $>80 \%$ \\
\hline Generating Mode & Grid parallel or islanded \\
\hline
\end{tabular}

\subsection{System Design}

\subsubsection{Engine-Generator}

The overall design concept for the micro-CHP system is based upon the use of a proven and efficient, high-durability gas engine-generator developed specifically for residential energy applications. The engine-generator, known as Ecopower, is sold in Europe as a co-generation system for hydronic heating and hot water. Its quiet, low-emission, IC engine is capable of operating with natural gas or propane, has a recommended maintenance interval of 4,000 hours, and an expected life of 40,000 hours. The engine is directly coupled to a high-efficiency $4.7-\mathrm{kW}$ generator. $12.5 \mathrm{~kW}$ of thermal energy recovered from the engine are provided for heating loads. The engine/generator is manufactured by Marathon Engine Systems in East Troy, WI, and was originally developed to power the Triathlon gas heat pump manufactured by York International.

For heating needs in all climates, the system recycles heat from the engine coolant and exhaust gases. Heat from the engine is used for space heating, domestic hot water, desiccant dehumidification, or other heating loads typically supplied hydronically, e.g., pool/spa heating.

The $4.7 \mathrm{~kW}$ capacity of the proposed micro-CHP system presents a good compromise between adequate standby power and efficiency. The system is electrically interconnected to the grid, and will also be capable of operating independent of the grid. The added security of being able to operate independent of the grid provides a sizable intangible benefit to justify the added investment for the CHP.

With batteries for peak intermittent loads, the generator has sufficient capacity for 3 - 4 tons of air conditioning supplemented by thermally activated desiccant cooling, plus another $1 \mathrm{~kW}$ for additional electric load. Its $12.5 \mathrm{~kW}$ of recovered heat is sufficient for most of the thermal energy requirements of the home. A significantly smaller system would not have the capacity to supply the bulk of the residential heating load, requiring much of the heating load to be provided by non-CHP conventional heating equipment. 


\subsubsection{Heating}

While household heating loads might be supplied via a heat pump driven by the engine or by the electricity produced by it, this would eliminate the opportunity to utilize the heat rejected by the engine and would reduce the energy-efficiency of the CHP system. Heating loads might also be supplied via a thermally activated heat pump, such as an absorption heat pump. However, the relatively low heat utilization temperature $\left(\sim 180^{\circ} \mathrm{F}\right)$ provided by the engine coolant does not allow a thermally activated heat pump to achieve a useful efficiency. Although the engine exhaust is at a much higher temperature, this represents only about half of the heat rejected by the engine. Absorbing the engine's jacket and exhaust heat in the engine coolant simplifies heat recovery and energy storage.

For reasons that are described below, the engine coolant is not used directly for heating applications, but is used to heat hot water. The hot water can by applied effectively and economically for space and domestic hot water heating via water-to-air and water-to-water heat exchangers.

The $12.5 \mathrm{~kW}(42,650 \mathrm{Btu} / \mathrm{hr})$ heat output from the engine is sufficient for most residential space heating and domestic water heating loads. In colder climates or for peak thermal loads, a supplemental heat source is employed in the form of either a boiler or gas/electric water heater.

\subsubsection{Cooling}

Heat recovered from the engine is used for latent cooling by desiccant dehumidification. Sensible cooling is provided by conventional vapor-compression air conditioning. Absorption cooling was considered but rejected as the mode of thermally activated cooling. The relatively low temperature of heat recovery and thermal storage limits the achievable cooling coefficient of performance (COP) to that of a single-effect refrigeration system, which at best can achieve a COP of about 0.7 . The available $12.5 \mathrm{~kW}$ of heat would provide at most about 2.5 tons of absorption cooling. Previous experience with engine-driven thermally activated cooling (e.g., the 3-ton York Triathlon) showed that the larger house size typical of this market generally requires significantly greater cooling capacity. It would be expensive and impractical to supplement an inadequate absorption cooling capacity with the addition of a vapor-compression air-conditioner. Rather, the desiccant-based latent cooling combined with mechanical ventilation provides superior indoor air quality and comfort in an energy efficient manner with independent humidity control.

A ventilation unit, which is combined with the desiccant dehumidifier, provides a constant supply of outdoor air to maintain indoor air quality. The desiccant dehumidifier dries the ventilation supply air, thereby reducing or eliminating the latent cooling load. Although the dehumidifier also warms the dried air, which increases the sensible cooling load, the total cooling load is reduced. Additional energy savings may be gained by allowing the airconditioner evaporator to operate at a higher temperature, since it no longer is required to dehumidify the conditioned air. A humidifier adds moisture to the conditioned air when the outside air is drier in order to maintain a desired humidity level in the conditioned space. By supplying makeup air only, the ventilation unit relies on exfiltration through building leakage paths to balance the airflow in the building. This increases the building internal pressure, 
thereby reducing infiltration of unconditioned air. This is beneficial in warm, humid climates, but can create moisture condensation problems in the building insulation in colder climates.

\subsubsection{Energy Storage}

The electrical and thermal energy loads in a residence are seldom coincident. In order to maximize CHP energy utilization efficiency, some form of energy storage is required. When connected to the electrical grid in a net-metering mode, the grid becomes an efficient electric "storage" device, accepting electric power when generation exceeds the internal load and delivering power when the load exceeds internal generation. For off-grid generation when operating in the standby or backup mode, electric storage batteries are used to limit engine cycling and for peak intermittent loads.

Thermal energy is most effectively and economically stored as hot water. The water-based heating fluid can be plain water, as in most hydronic boilers, or it can contain inhibitors and/or glycol antifreeze similar to that used in some hydronic heating systems. The stored hot water then becomes the thermal energy transfer medium to convey co-generated heat to the various thermal loads: domestic hot water, space heating (hydronic), and thermally-activated desiccant cooling.

Energy stored in the TSU enables the engine to run longer when supplying heat, and to remain off longer, thereby reducing engine cycling. Engine cycling should be minimized in order to reduce cyclic thermal losses and to reduce engine starts, which are the most significant cause of engine wear. The TSU has an auxiliary heater, such as an electric heater or gas burner, to provide supplementary heat input when engine heat is inadequate or unavailable.

\subsubsection{Fuel}

In most applications where the home is connected to the grid, natural gas is available and is the most economical fuel source. Where natural gas is unavailable, LPG (propane) and fuel oil are secondary choices. While LPG is an acceptable fuel for the Ecopower engine, fuel oil is not. Although it may be technically feasible to modify the Ecopower engine to operate as a diesel, this would be costly, and its exhaust emissions are more difficult and expensive to treat in order to satisfy emission standards. In view of the added cost and limited applications, there are no plans for a diesel version.

\subsubsection{Modular Design}

A CHP system comprising the generator, 50 to 100 gallons of thermal storage, a heating, ventilating, and air conditioning (HVAC) system, and domestic hot water (DHW) system is too large to be incorporated within a unitary package. Rather, the proposed system is designed as an integrated modular system. Furthermore, the choices of HVAC and DHW systems are too great to be supplied by the CHP manufacturer. Rather, the approach will be to offer a pre-engineered CHP package comprising generator and thermal interface modules that can couple with any TSU, DHW, and HVAC system. Furthermore, a limited line of pre-engineered TSU, TSU, and HVAC modules will be offered for those who prefer a single source of pre-specified components. 
The system consists of 6 main application modules plus a thermal interface module, as illustrated in Figure 9:

- Gen-set Module consisting of the engine/generator, coolant pump and thermostat, coolant-to-TSU heat exchanger, and electrical interface and controls;

- Thermal Storage Unit (TSU) consisting of the thermal storage tank, its expansion tank and supplementary heater;

- DHW Module consisting of the domestic hot water storage tank, potable water pump, and heater exchanger ${ }^{6}$;

- Air handler Module containing circulating fan, air-conditioning coil, and space-heating hydronic coil;

- Outdoor Condensing Unit containing $\mathrm{A} / \mathrm{C}$ condenser and compressor;

- Desiccant Ventilator/Dehumidifier containing the supply-air blower and desiccant wheel, sensible heat recovery wheel, regeneration air-heating coil, and regeneration-air blower;

- Thermal Interface Module containing the TSU heating pump, TSU charging pump, supply and return manifolds and switching valves, thermal system controls and piping connections. The heating fluid is circulated to a distribution manifold, from which it can be directed to a space-heating coil in the air handler, a domestic hot-water heat exchanger, or a regeneration-air heating coil in the desiccant dehumidifier.

The electrical interface with the grid and the electrical load will be part of the gen-set module. The gen-set interfaces with the thermal system through the thermal interface module. The thermal interface will be a factory assembled module that provides all of the piping and control interfaces necessary for storage and application of heat recovered from the engine.

\footnotetext{
${ }^{6}$ The present system employs a do mestic hot water (DHW) storage tank with an external heat exchanger. This requires a potable water pump to circulate DHW between the tank and heat exchanger. An alternative is a DHW tank with an internal heat exchanger, which avoids the need for a DHW pump.
} 


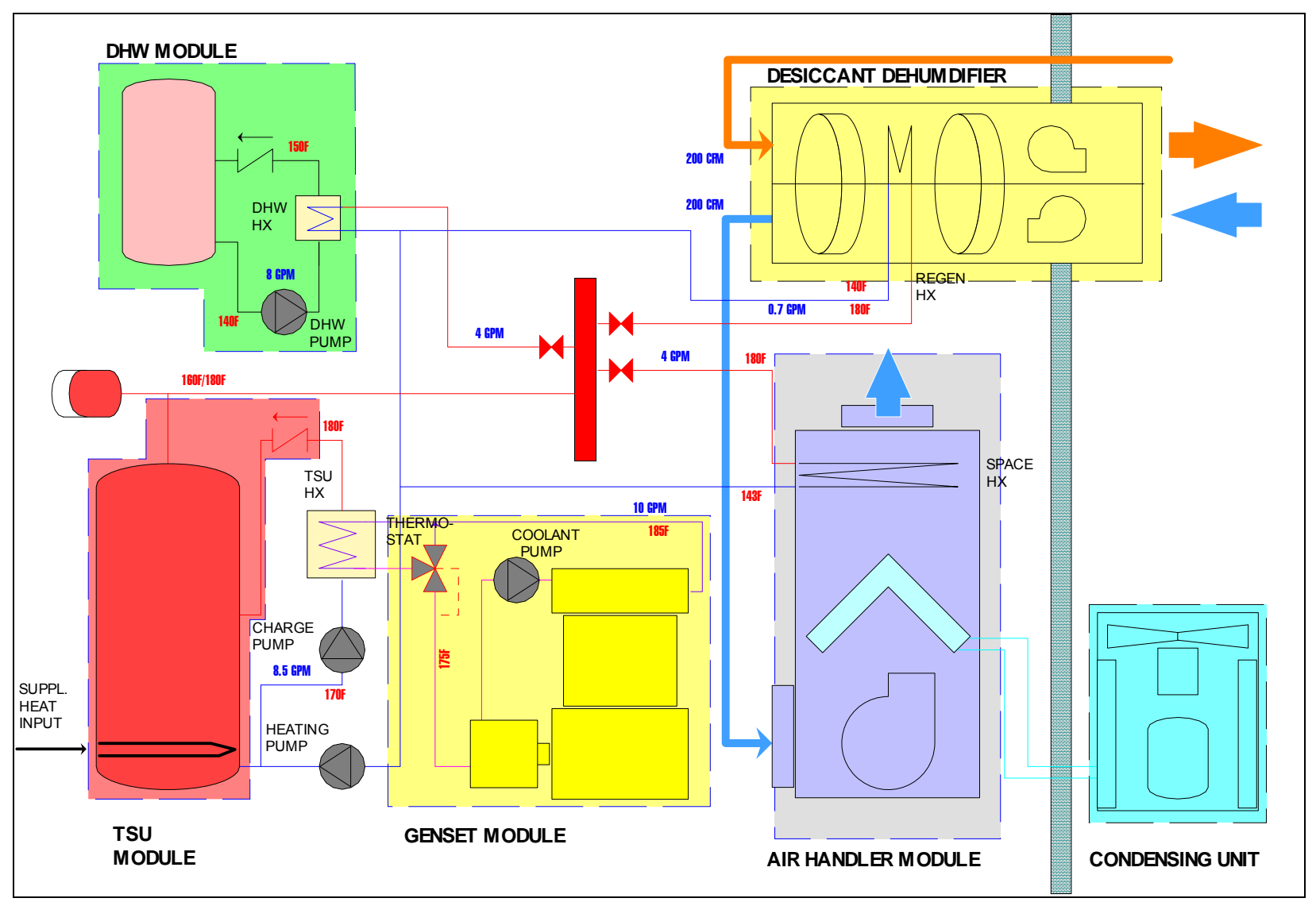

Figure 9. Micro-CHP Modules

The overall performance characteristics of the micro-CHP system are summarized in Table 15. These are well matched to the performance requirements of the intended applications.

Table 15. Micro-CHP Performance Specifications

\begin{tabular}{|l|c|}
\hline Parameter & Value \\
\hline Fuel & Natural Gas, Propane \\
\hline Grid Connection & Parallel, Islanded, Automatic Backup \\
\hline Electric Power & $2-4.7 \mathrm{~kW}$ \\
\hline CHP Thermal Output & $6-12.5 \mathrm{~kW}$ \\
\hline Electric Generation Efficiency & $22.5 \%$ \\
\hline Overall Thermal Efficiency & $80 \%$ \\
\hline Supplemental Thermal Output & $4.5-12 \mathrm{~kW}$ \\
\hline Space Heating, Hydronic & $12.5-24.5 \mathrm{~kW}$ \\
\hline Space Cooling, Electric & Vapor Compression, 3-5 RT \\
\hline Domestic Hot Water, Hydronic & $40-50$ gallon, $12.5 \mathrm{~kW}$ recovery \\
\hline Desiccant Dehumidifier & 200 CFM, 0.4-0.7 RT \\
\hline Thermal Storage & $50-100$ gallon, 4.5-12 kW supplemental heat input \\
\hline
\end{tabular}




\subsection{Micro-CHP Component Designs}

The designs of the component modules of the micro-CHP system are described in the following sections.

\subsubsection{Engine-Generator}

The Get-Set module consists of the engine-generator, together with its controls and heat recovery and dissipation system. The engine-generator is a developed system currently marketed in Europe as the Ecopower. The single-cylinder, 4-stroke, liquid-cooled engine provides $4.7 \mathrm{kWe}$ of power and $12.5 \mathrm{~kW}$ of thermal energy. It is designed for $40,000 \mathrm{hr}$ life and its maintenance interval is every 4,000 hours, or annually. Periodic maintenance consists of oil change, replacement of oil and air filters, spark plug, ignition cable, engine check over the entire speed range, adjustment of exhaust gas emissions; and visual inspection of all components. Basic specifications of the Ecopower system are listed in Table 16.

Table 16. Ecopower Specifications

\begin{tabular}{|l|l|l|}
\hline Parameter & Units & Amount \\
\hline Electrical Power & $\mathrm{kWe}$ & 4.7 \\
\hline Thermal Output & $\mathrm{kW}$ & 12.5 \\
\hline Gas Input (HHV) & $\mathrm{kW}$ & 20.82 \\
\hline Electrical Efficiency (HHV) & & $22.6 \%$ \\
\hline Overall Efficiency (HHV) & & $82.6 \%$ \\
\hline Power Modulation & & $2.3: 1$ \\
\hline Thermal Modulation & & $2.1: 1$ \\
\hline Engine Speed & $\mathrm{RPM}$ & $1700-3600$ \\
\hline Bore & in & 2.875 \\
\hline Stroke & in & 2.559 \\
\hline Compression Ratio & & 12.8 \\
\hline Sound Pressure Level & $\mathrm{dB}(\mathrm{A})$ & $<56$ \\
\hline Dimensions & in & $54 \mathrm{Lx} 30 \mathrm{Dx} 43 \mathrm{H}$ \\
\hline Weight & $\mathrm{lb}$ & 858 \\
\hline
\end{tabular}

Although the engine is capable of about 3:1 speed modulation, to maintain high efficiency and robust operation at low speed operational speed range is generally limited to about $2: 1$. The fuel input rate and power output over a speed range of 1500 to 3600 is shown in Figure 10. The engine-generator assembly is shown in Figures 11 - 13. The acoustic enclosure (Figure 11) enables it to be installed indoors, much like a conventional boiler. The liquid-cooled permanent-magnet generator is cantilevered on the engine flywheel. Engine coolant is circulated through the generator to the coolant pump, to the cylinder jacket and cylinder head, to the exhaust manifold, and to a plate-type engine-coolant-to-heating-fluid heat exchanger. The heating fluid cools the engine coolant, taking the place of the engine radiator. Electrical power is modulated by varying the engine speed in response to generator torque, allowing the engine to remain at wide-open throttle at all loads. This avoids throttling losses, resulting in high efficiency over the entire load range. 


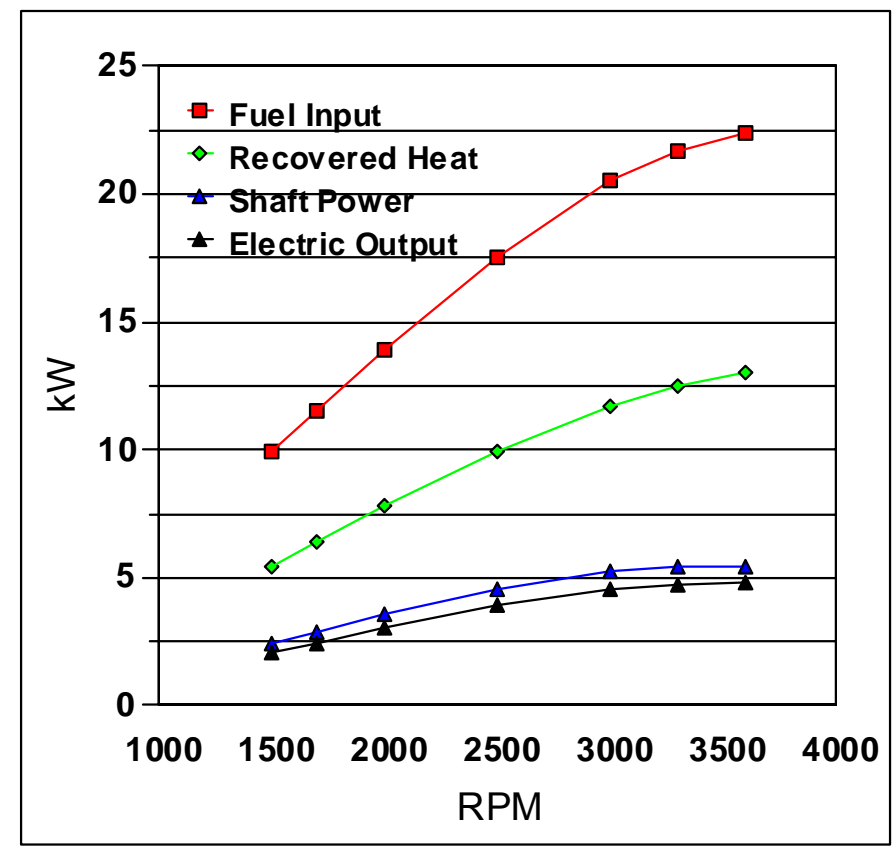

Figure 10. Engine Fuel Input and Power Output

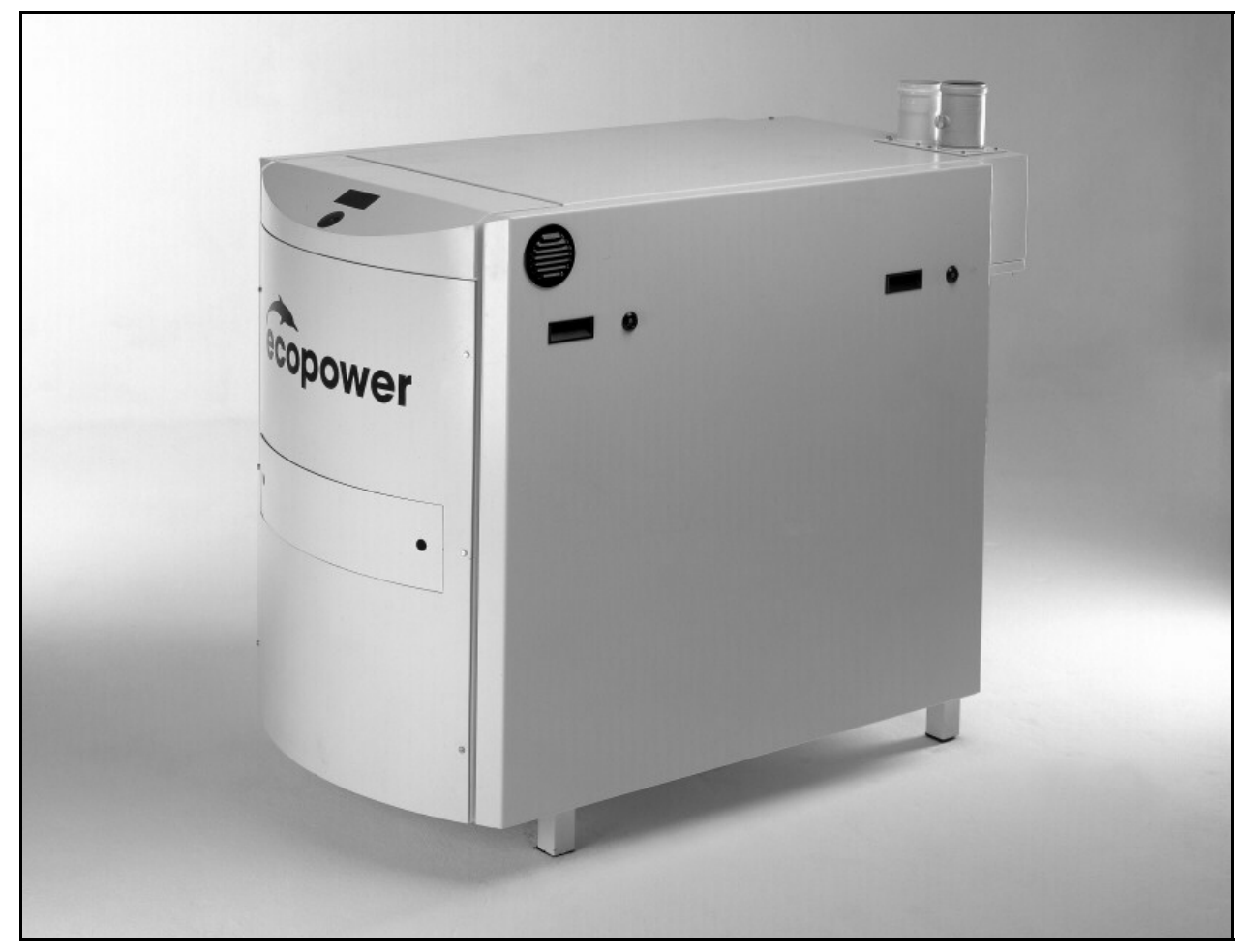

Figure 11. Ecopower Enclosure 


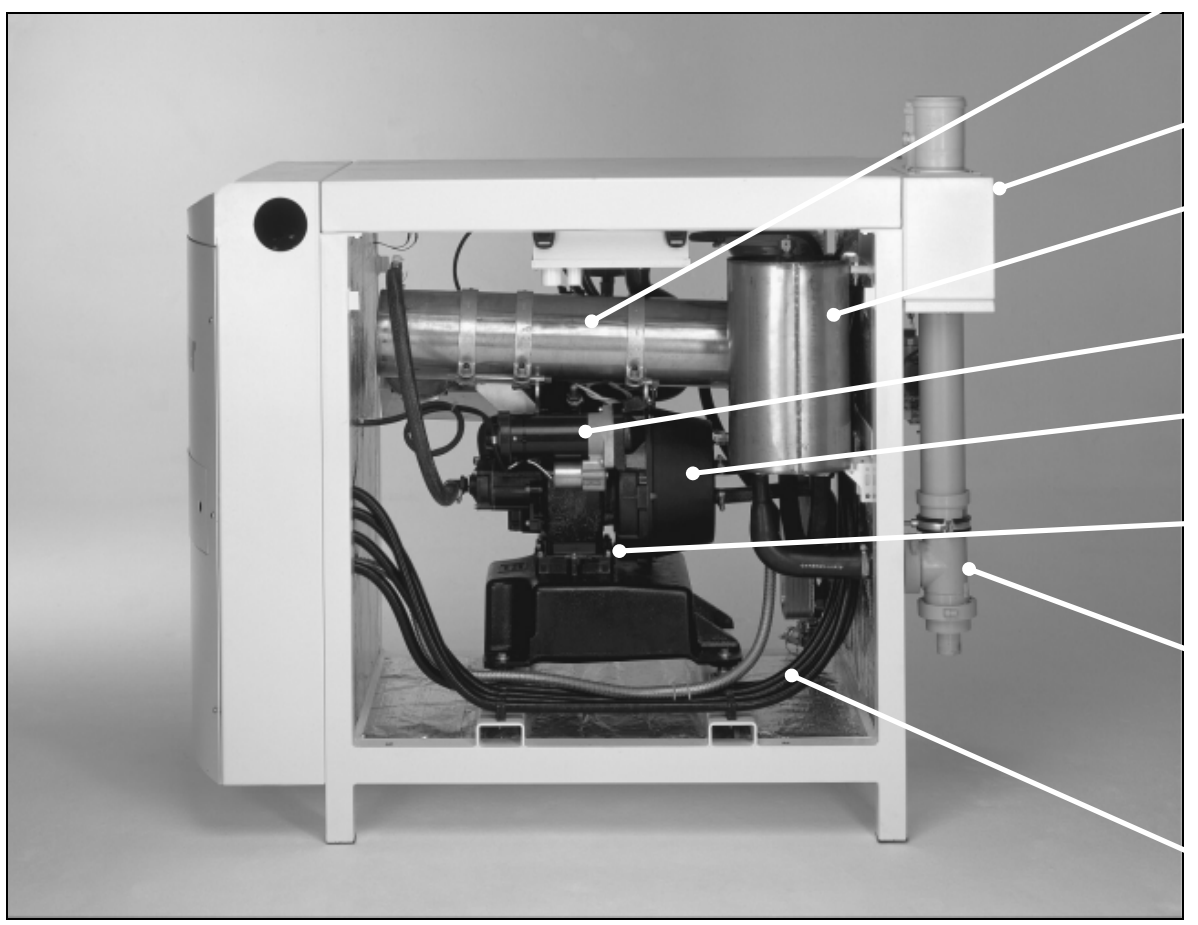

Exhaust gas

heat recuperator

Connection box

Exhaust gas

muffler

Starter

Generator

Engine with oil sump

Exhaust gas pipe with condensate drain

Electric

connections

Figure 12. Right Side View of Ecopower Module with Open Side Panels.

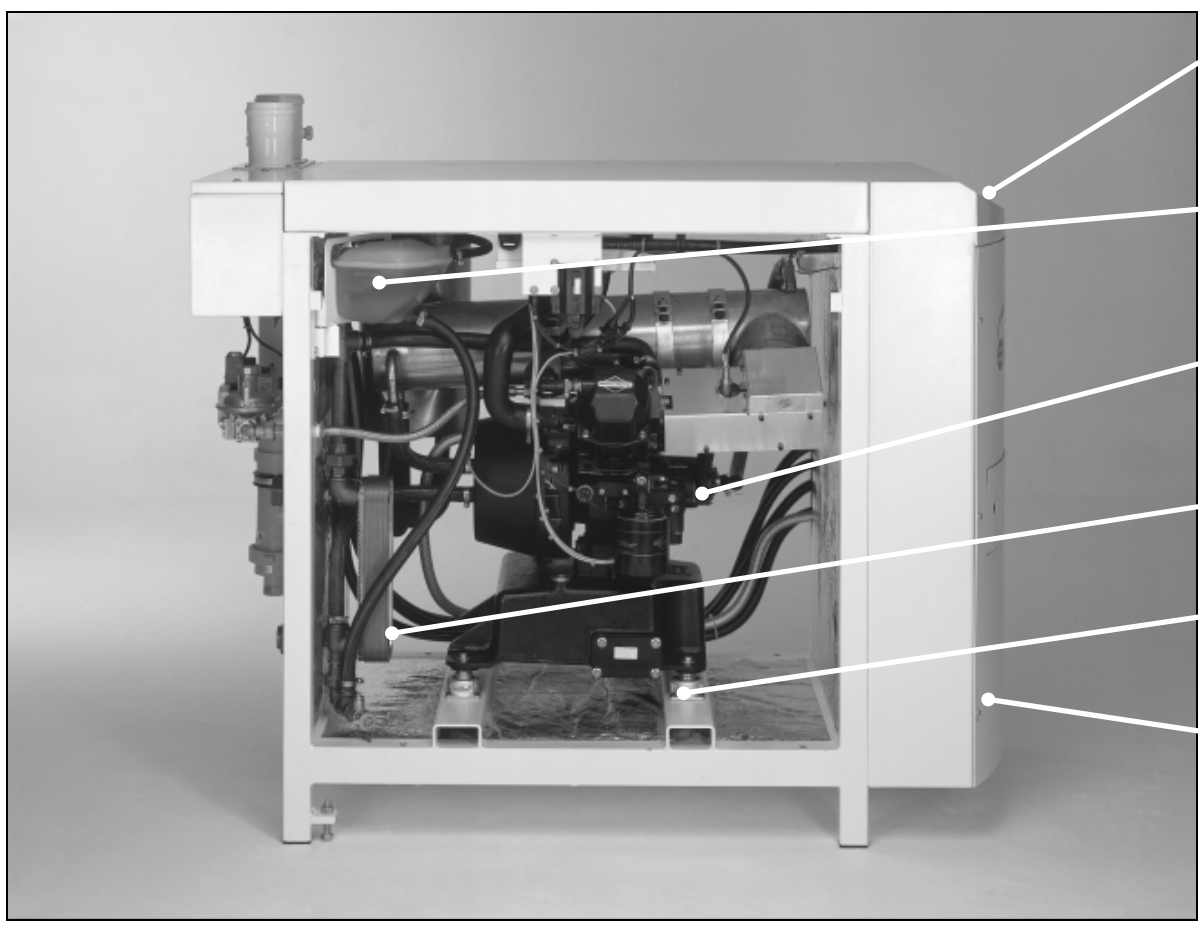

Controls

Expansion

vessel

Coolant pump

Plate heat exchanger

Engine shock mount

Control box

Figure 13. Left Side View of Ecopower Module with Open Side Panels 
The current Ecopower system operates only in parallel with the grid. In the event of a grid failure, the Ecopower also shuts down. The Ecopower module is designed for indoor installation. The cooled engine exhaust gases are vented to the outside through plastic exhaust piping. All other piping and wiring connections are indoors.

Other engine-generators produced by Marathon similar to the Ecopower operate as stand-alone generators islanded from the grid. A major modification to meet the requirements of the microCHP system will be to develop the operating controls and safety systems necessary to permit continuous backup mode, in which the system operates normally in parallel with the grid, with automatic switch-over to stand-alone operation in the event of a grid failure. In addition to the controls modifications, an outdoor radiator will be required to dissipate engine heat when the TSU is fully charged and there is no other heat load in the residence.

The major changes for the proposed micro-CHP system include:

- Grid-parallel or stand-alone operation

- Battery storage (for stand-alone operation)

- Engine heat rejection radiator (for stand-alone electric power generation when thermal storage is saturated)

\subsubsection{Thermal Storage Unit (TSU)}

The thermal interface between the gen-set and the thermal loads is the Thermal Storage Unit (TSU). The TSU may be viewed as a hydronic "heating boiler" storing hot water, with the engine as its heat source. Although the gen-set is intended to follow the thermal load and is able to modulate its thermal output over a considerable turndown range, some form of thermal storage is required in order to minimize start-stop cycles and to enable the power system to operate at its most efficient level. Engine cycling must be minimized, since it is responsible for much of the engine wear. Short-cycling must also be avoided in order to minimize cyclic thermal losses that reduce both electric power output and thermal recovery.

The application and benefits of thermal storage are illustrated by the following example. Consider a CHP system having a fixed thermal output of $12.5 \mathrm{~kW}(42,660 \mathrm{Btu} / \mathrm{hr})$. The engine will cycle at any continuous load less than $12.5 \mathrm{~kW}$. Assume that the TSU has a heat capacity of $10,000 \mathrm{Btu}$ (e.g., 50 gallons of water with a temperature swing of $24^{\circ} \mathrm{F}$ ). This thermal storage capacity can maintain a heat load of 20,000 Btu/hr for a half hour. The engine must then run for approximately a half hour (26.5 minutes) to re-charge the TSU while maintaining the 20,000 $\mathrm{Btu} / \mathrm{hr}$ heat load. This would result in an average of 25 engine starts per day at this constant load. If now the engine can modulate down to a thermal output of $6 \mathrm{~kW}(20,480 \mathrm{Btu} / \mathrm{hr})$, then the engine will not cycle at any continuous load higher than $6 \mathrm{~kW}$. Below this load, the engine will again cycle, but at a lower frequency.

This relationship between cycling frequency and thermal load is shown in Figure 14. The cycling frequency is inversely proportional to thermal storage capacity and is highest at a load 
equal to $50 \%$ of the minimum thermal output. The ability to modulate the output reduces the maximum frequency, and eliminates cycling entirely above its minimum output.

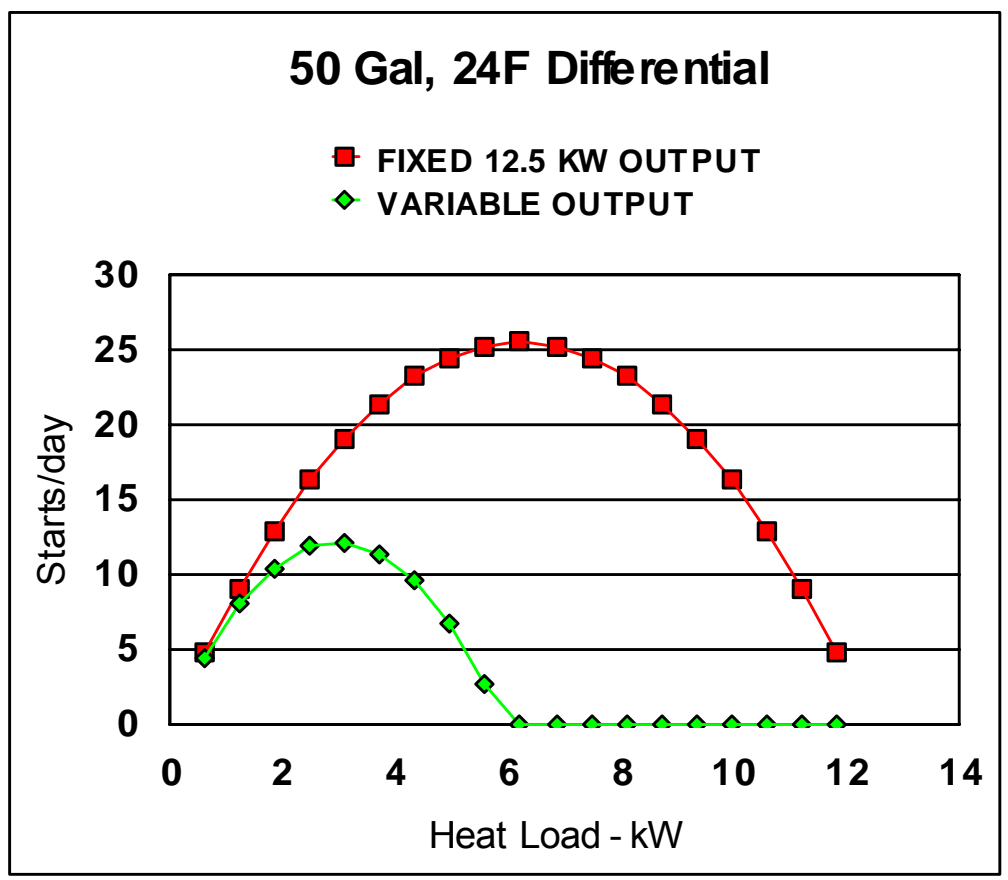

Figure 14. Engine Starts versus Heat Load

Several TSU design options were evaluated:

Option A - Store engine coolant. The advantage of this option is that it avoids the need for an intermediate heat exchanger between the engine coolant and the thermal storage fluid. This eliminates the need for the heat exchanger and a circulating pump. Since there is no drop in temperature through the heat exchanger, the maximum storage temperature can be higher, resulting in smaller HVAC and DHW heat exchangers and/or greater stored energy in the TSU. The main disadvantages stem from the fact that the engine coolant is composed of an aqueous glycol solution in a concentration of $30 \%$ to $50 \%$. Such high concentrations reduce the heat capacity and heat transfer coefficient in comparison to water, requiring a larger storage vessel and larger, more powerful pumps and/or larger heat exchangers. Furthermore, the relatively high cost of glycol coolant ( $>\$ 3.00 /$ gal) increases the cost of energy storage.

Option B - Storage tank with integral heat exchanger. In this version the storage vessel contains an internal heat exchanger. This avoids the need for a separate pump to circulate the thermal storage fluid through the heat exchanger. The disadvantage is that it requires a special storage tank that is different from standard water heaters that are produced in high volume. This increases first cost significantly, and is likely to increase maintenance cost if and when the storage tank needs to be replaced.

Option C - Standard water heater with external heat exchanger. This version uses a standard gas or electric water heater as the storage vessel. A small pump circulates the thermal storage fluid 
through an external heat exchanger, which is heated by engine coolant. A variety of relatively inexpensive standard water heaters can be used. Cooler fluid is drawn from the base of the storage tank to be heated and returned to the top of the tank, thereby thermally stratifying the tank. When heat is required by the HVAC or DHW systems, hotter fluid is drawn from the top to the tank and is returned to the base of the tank, thereby maintaining stratification. In this manner, it is possible for the temperature of the fluid supplied from the tank to be considerably hotter than the average tank temperature. This maximizes the effective thermal storage capacity of the tank. A portion of the savings in comparison to Option B are traded off against the cost of the circulator, but generally the external heat exchanger is less costly than an internal one, so Option $\mathrm{C}$ is generally the least expensive.

In addition to providing a thermal storage function, the TSU also provides backup or supplemental heating when heat from the CHP system is unavailable or inadequate for the heat load. Both gas and electric water heaters are suitable for the TSU. In warmer climates where there may be little or no need for supplemental heating, the lower standby loss of an electric water heater makes it more efficient than a gas water heater. Examples of gas and electric water heaters are shown in Tables 17 and 18. Standard residential electric water heaters can provide about 15,000 - 19,000 Btu/hr (4.5 - 5.5 kW) of supplemental or backup heat, which may be adequate for warmer climates. In colder climates where additional heat input is likely to be needed to supplement the $12.5 \mathrm{~kW}$ from the CHP unit, a standard 40,000 Btu/hr gas water heater can provide an additional $32,000 \mathrm{Btu} / \mathrm{hr}(9.4 \mathrm{~kW})$ at an efficiency of about $80 \%$. Its disadvantage in comparison to an electric water heater is its higher standby loss. A 50-gallon electric water heater will lose about $2,100 \mathrm{Btu} /$ day at a storage temperature of $180^{\circ} \mathrm{F}$, versus about 23,000 Btu/day for a standard center-flue gas water heater.

Larger water heaters provide greater energy storage capacity, but are considerably more expensive and have greater standby losses. AO Smith's 100-gallon gas water heater would have a standby loss of about $45,000 \mathrm{Btu} /$ day at a $180^{\circ} \mathrm{F}$ storage temperature. AO Smith also makes a high-efficiency gas-fired 100-gallon water heater with a recovery efficiency of $95 \%$ and a standby loss of only about $21,000 \mathrm{Btu} /$ day at $180^{\circ} \mathrm{F}$. This unit has an input of $150,000 \mathrm{Btu} / \mathrm{hr}$ and is considerably more expensive than a standard gas water heater. However, it may be suitable for selected applications that have above-average infrequent heating loads, such as for pool/spa heating.

A water heater for use as a TSU would be modified by the addition of a pair of TSU supply and return fittings, in addition to the standard "hot" and "cold" fittings. The hot and cold fittings would be connected to the supply and return, respectively, of the thermal loads. The auxiliary supply fitting would be located near the base of the water heater and would connect to the inlet of the coolant-to-TSU heat exchanger. The auxiliary return fitting would return heated TSU fluid to the upper half of the tank.

Another modification would be required for a gas-fired TSU. When the CHP system is operating in an islanded mode it is required to satisfy demands for both heat and power. When responding to an electrical load, excess heat is rejected to an outdoor radiator. When responding to a thermal load, excess electrical power is dissipated to an electric heating element in the TSU. This employs the standard heating element in an electric water heater. When a gas water heater 
is used for the TSU, it is modified by the addition of an electric heating element, thus becoming a "dual-fuel" water heater.

Table 17. Efficiency and standby losses of gas water heaters

\begin{tabular}{|c|c|c|c|}
\hline \multirow{2}{*}{\begin{tabular}{|l|} 
\\
Parameter
\end{tabular}} & \multirow[b]{2}{*}{ Units } & \multicolumn{2}{|c|}{ Model } \\
\hline & & XGV-50 & FCG-100 \\
\hline Purpose & & TSU & TSU \\
\hline Storage Volume & Gal & 50 & 98 \\
\hline First Hour Rating & Gal & 97 & $\mathrm{~N} / \mathrm{A}$ \\
\hline EF & & 0.63 & 0.52 \\
\hline BTU Input & $\mathrm{Btu} / \mathrm{hr}$ & 40,000 & 75,100 \\
\hline Recovery 90F Rise & $\mathrm{Gal} / \mathrm{hr}$ & 44 & 81 \\
\hline R Value & & 16 & 10 \\
\hline Shipping Weight & $\mathrm{lb}$ & 195 & 350 \\
\hline Diameter and Height & in & $22 / 59.5$ & $26.5 / 65$ \\
\hline Ambient Temp & $\operatorname{deg} \mathrm{F}$ & 70 & 70 \\
\hline Recovery Efficiency & $\%$ & 81 & 80 \\
\hline High Temp Storage: & & $180^{\circ} \mathrm{F}, \mathrm{T}_{\mathrm{an}}$ & \\
\hline Storage Temp & $\operatorname{deg} F$ & 180 & 180 \\
\hline Standby Loss & Btu/day & 23,365 & 45,155 \\
\hline
\end{tabular}

Table 18. Efficiency and standby losses of electric water heaters

\begin{tabular}{|c|c|c|c|c|}
\hline & & \multicolumn{3}{|c|}{ Model } \\
\hline Parameter & Units & PXHT 40 & PXHT 52 & PXHT 80 \\
\hline Purpose & & DHW & $\begin{array}{c}\text { DHW } \\
\text { and/or TSU }\end{array}$ & TSU \\
\hline Storage Volume & Gal & 40 & 50 & 80 \\
\hline First Hour Rating & Gal & 56 & 60 & 81 \\
\hline EF & & .95 & .95 & .95 \\
\hline Element Wattage & Std/Max & $4500 / 5500$ & $4500 / 5500$ & $4500 / 5500$ \\
\hline Recovery 90F Rise & $\mathrm{Gal} / \mathrm{hr}$ & 21 & 21 & 21 \\
\hline R Value & & 24 & 24 & 24 \\
\hline Shipping Weight & $\mathrm{lb}$ & 125 & 140 & 225 \\
\hline Diameter and Height & in & $20 / 60.5$ & $22.5 / 57$ & $26 / 62$ \\
\hline Ambient Temp & $\operatorname{deg} \mathrm{F}$ & 70 & 70 & 70 \\
\hline Recovery Efficiency & $\%$ & 98 & 98 & 98 \\
\hline Low Temp Storage: & \multicolumn{4}{|c|}{$\mathrm{T}_{\mathrm{H}}=140^{\circ} \mathrm{F}, \mathrm{T}_{\mathrm{amb}}=70^{\circ} \mathrm{F}$} \\
\hline Storage Temp & $\operatorname{deg} F$ & 140 & 140 & 140 \\
\hline Standby Loss & Btu/day & 1237 & 1356 & 1723 \\
\hline High Temp Storage: & \multicolumn{4}{|c|}{$\mathrm{T}_{\mathrm{H}}=180^{\circ} \mathrm{F}, \mathrm{T}_{\mathrm{amb}}=70^{\circ} \mathrm{F}$} \\
\hline Storage Temp & $\operatorname{deg} \mathrm{F}$ & 180 & 180 & 180 \\
\hline Standby Loss & Btu/day & 1943 & 2131 & 2707 \\
\hline
\end{tabular}


As illustrated in Figure 9, hot water stored in the TSU is supplied to the supply manifold of the thermal system by a heating pump that draws water from the top of the tank and returns it to the bottom of the tank. The hot and cold water fittings of a standard electric water heater should serve this function. When recharging is required, a second charge pump draws water from the bottom of the tank together with any return water from the thermal system and supplies it to the coolant-to-water TSU heat exchanger, from which it is returned to the top of the TSU tank. The water flow to the TSU heat exchanger is thermostatically controlled to maintain the discharge water temperature at $175^{\circ} \mathrm{F}-180^{\circ} \mathrm{F}$ for delivery to the TSU. This is subject to the constraint that the heat removal from the engine coolant is sufficient to maintain the coolant supply temperature from the engine at its nominal design temperature of $185^{\circ} \mathrm{F}$.

The objective of the TSU control is to minimize engine cycling while maintaining sufficient TSU temperature for supplying the thermal loads. A preliminary engine control algorithm for maintaining the TSU storage temperature is illustrated in Figure 15. If the TSU tank thermostat drops below $160^{\circ} \mathrm{F}$ and there is no thermal load, the TSU will be recharged by its auxiliary energy source; i.e., its electric heating element or gas burner. If there is a coincident thermal load, the engine will start, and following its warm-up cycle, it will modulate its thermal output within a thermostat temperature band of $150^{\circ} \mathrm{F}$ to $170^{\circ} \mathrm{F}$. Above $170^{\circ} \mathrm{F}$ the engine will continue to run until either the TSU thermostat reaches $180^{\circ} \mathrm{F}$ or the engine coolant reaches its upper temperature limit of $190^{\circ} \mathrm{F}$.

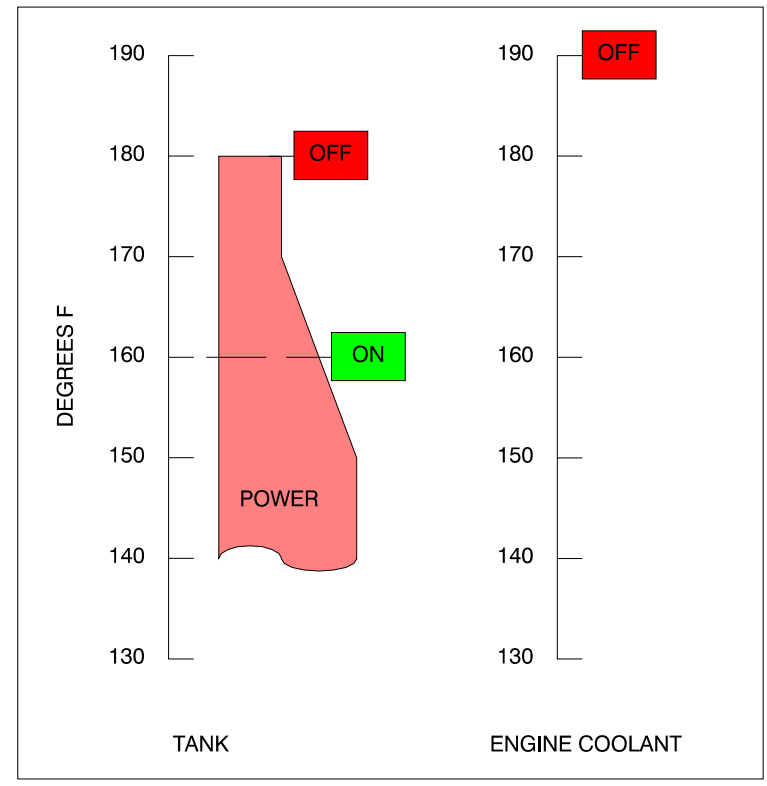

Figure 15. TSU Control Mode

The TSU heating fluid will be water. Since the TSU fluid loop is a closed system, the water will be de-aerated and should have only minor corrosion potential, much like boiler water. Freeze protection should not be necessary for an indoor installation. A corrosion inhibitor may be desirable to maintain long-term system integrity. A diaphragm-type expansion tank will be employed to maintain and limit system pressure as the fluid density changes due to varying temperature. 
The TSU is heated by the engine coolant-to-TSU heat exchanger located within the gen-set module. This heat exchanger has a two-fold purpose: One is to cool the engine coolant. The desired engine coolant supply and return temperatures are $185^{\circ} \mathrm{F}$ and $175^{\circ} \mathrm{F}$, respectively ${ }^{7}$. The other objective is to heat the TSU fluid to as a high temperature as is practical, in order to maximize the thermal storage capacity of the TSU. These two objectives can be accomplished by limiting the flow rate of TSU water through the heat exchanger up to a point beyond which the engine coolant would overheat. The engine coolant flow rate to the heat exchanger is controlled by a three-way thermostatic valve (mixing valve) that blends hot coolant from the engine with cold coolant from the heat exchanger to maintain the desired $185^{\circ} \mathrm{F}$ coolant supply temperature. The TSU charge pump varies the TSU flow to the heat exchanger to maximize the temperature of the water returned to the TSU, subject to the constraint that the desired coolant return temperature is not exceeded. This will occur when the hot coolant that is bypassed past the heat exchanger by the thermostatic mixing valve is at a minimum. A charge-pump speedcontrol that senses the temperature rise across the coolant thermostatic mixing valve can accomplish this.

The estimated performance of a coolant-to-TSU heat exchanger using an AO Smith ProMax XL model RXLS52 plate-type heat exchanger is shown in Table 19. At the design heat input of 12.5 $\mathrm{kW}$ the heat exchanger will heat $4.3 \mathrm{GPM}$ of TSU water from $160^{\circ} \mathrm{F}$ to $179.8^{\circ} \mathrm{F}$ while cooling 10 GPM of coolant from $185^{\circ} \mathrm{F}$ to $175^{\circ} \mathrm{F}$; that is, with zero thermostatic bypass. At all lower water inlet temperatures and heat inputs, the heat exchanger will heat the water to $180^{\circ} \mathrm{F}$ while cooling a lower flow rate of coolant to less than $175^{\circ} \mathrm{F}$; that is, with thermostatically controlled bypass. Therefore, this heat exchanger should be capable of heating the TSU to $180^{\circ} \mathrm{F}$ while adequately cooling the engine.

Table 19. Estimated Performance of Coolant-to-TSU Heat Exchanger

\begin{tabular}{|l|c|c|c|c|c|}
\hline Heat Transfer & $\mathrm{kW}$ & \multicolumn{2}{|c|}{12.5} & \multicolumn{2}{c|}{6.3} \\
\hline Water In & $\operatorname{deg~F}$ & 160.0 & 140.0 & 160.0 & 140.0 \\
\hline Water Out & $\operatorname{deg~F}$ & 179.8 & 180.0 & 180.0 & 180.0 \\
\hline Water Flow & GPM & 4.3 & 2.1 & 2.1 & 1.1 \\
\hline Coolant In & $\operatorname{deg~F}$ & 185.0 & 185.0 & 185.0 & 185.0 \\
\hline Coolant Out & $\operatorname{deg~F}$ & 175.0 & 157.4 & 165.0 & 145.3 \\
\hline Coolant Flow & GPM & 10.0 & 3.6 & 2.5 & 1.3 \\
\hline
\end{tabular}

\subsubsection{Thermal Interface}

The Thermal Interface module couples the engine-generator to its thermal loads. It supplies engine heat to the Thermal Storage Unit (TSU), and through the TSU it connects with the space heating system, the domestic hot water (DHW) system, and the desiccant dehumidifier. The Thermal Interface is intended to be a factory-assembled and wired module ready to install at the

\footnotetext{
${ }^{7}$ With its current engine-driven coolant pump, the coolant flow is proportional to engine speed. In its wide-openthrottle (WOT) operating mode, the electric and thermal power vary roughly in proportion to engine speed. Consequently, the coolant temperature rise through the engine remains roughly constant at about $10^{\circ} \mathrm{F}$.
} 
site. All supervisory controls, flow controls, switching valves, pumps, etc., are pre-installed. The installer only needs to connect water pipe and control wires to the respective modules.

The thermal interface is shown schematically in Figure 16. The engine-coolant-to-TSU heat exchanger $^{8}$ is contained within the gen-set module, and connects to the Thermal Interface via the hot and cold TSU water lines. A TSU Charge-Pump circulates water from the bottom of the $\underline{\text { TSU tank }}$ to the Coolant-to-TSU Heat Exchanger, and back to the TSU (hot) Supply Manifold, which connects with the top of the TSU tank. The TSU Supply Manifold feeds the hydronic heating coil in the air handler module, the regeneration coil in the desiccant dehumidifier, and the TSU-to-DHW heat exchanger within the thermal interface. Cold return flow from the hydronic heating coil, the desiccant regeneration coil, and the TSU-to-DHW heat exchanger connects to the Return Manifold within the thermal interface. A Heater Pump draws the cold return flow back to the bottom of the TSU storage tank.

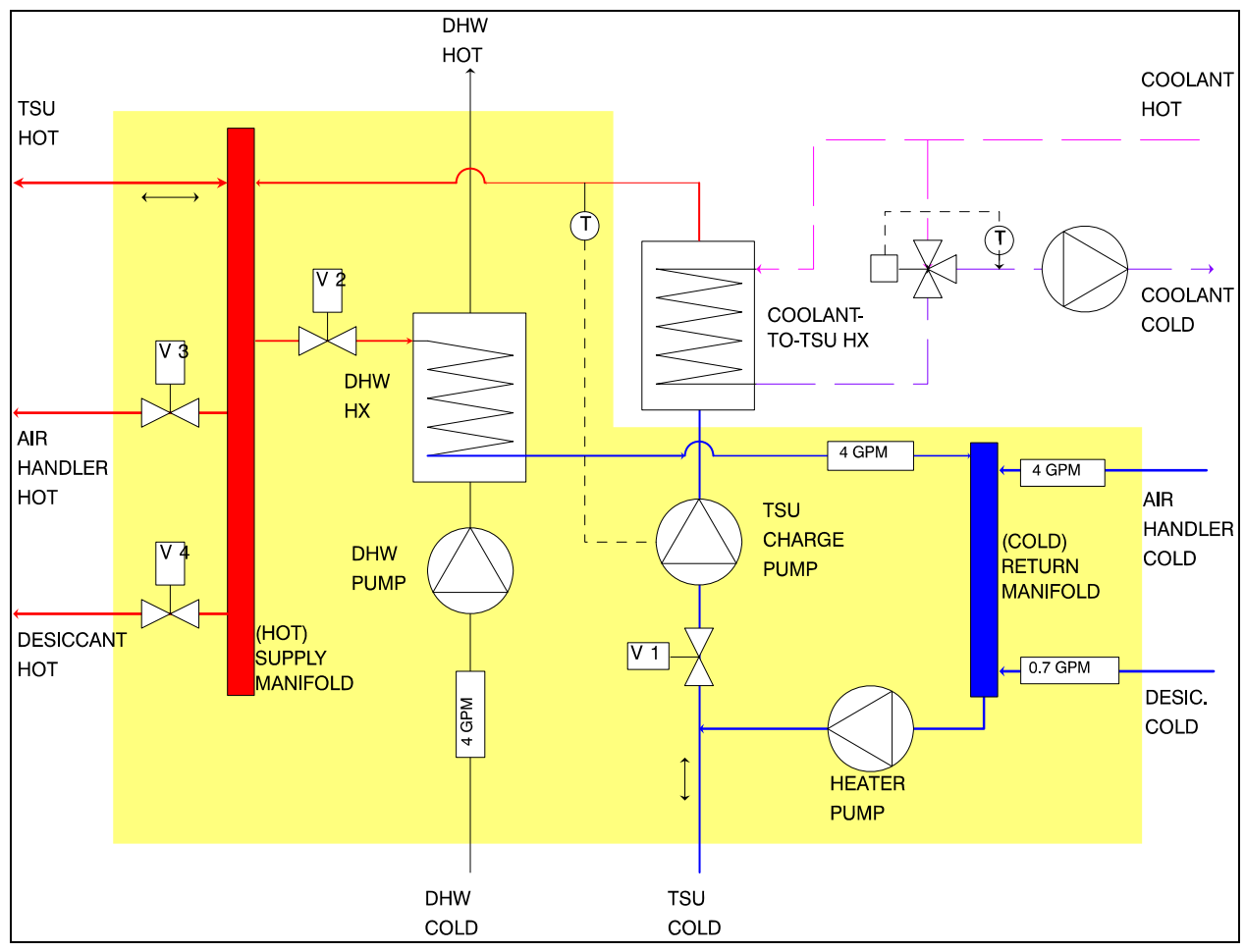

Figure 16. Thermal Interface Schematic

A preliminary packaging layout of the thermal interface is shown in Figure 17. This shows the supply manifold and switching valves, the return manifold and flow regulators, the variablespeed charging pump, and thermal interface relay box. This configuration omits the DHW heat exchanger, which would be mounted on the DHW storage tank or would be an integral part of an

\footnotetext{
${ }^{8}$ The coolant-to-water heat exchanger is contained within the gen-set module to avoid field piping of the engine coolant loop. The exception is when the gen-set is installed outdoors and there is a possibility of freezing. To avoid the need for anti-freeze prot ection of the TSU system, the coolant-to-water heat exchanger would be relocated indoors.
} 
indirect water heater. Alternately, a TSU-to-DHW heat exchanger and a DHW circulator can be included as part of the thermal interface, as depicted in Figure 16.

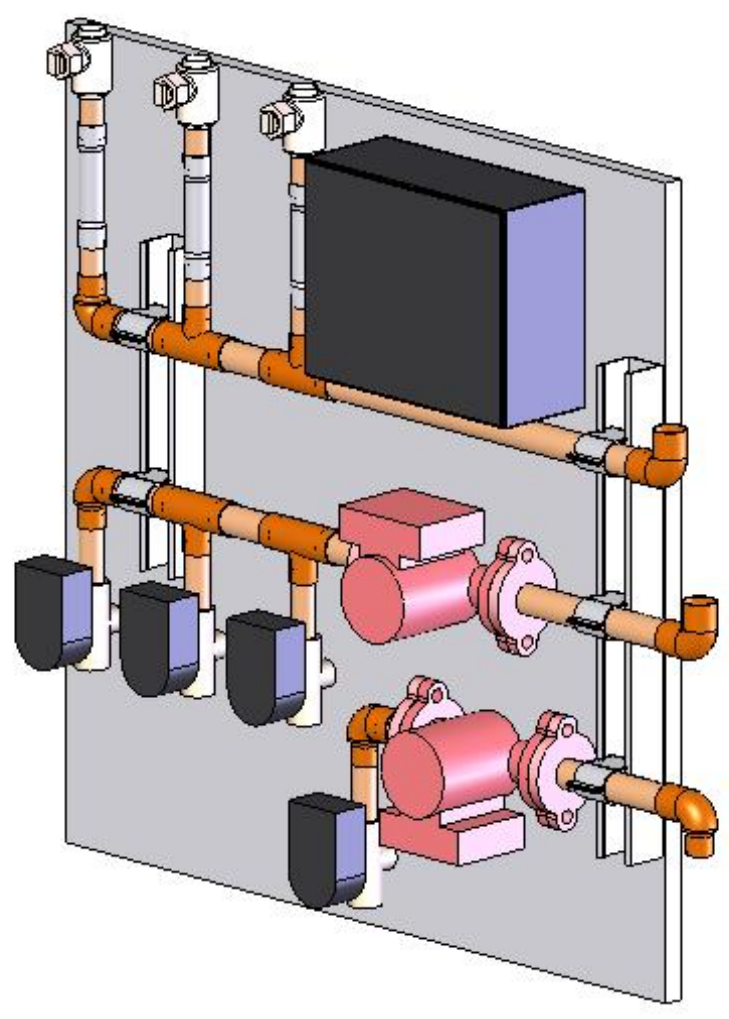

Figure 17. Thermal Interface Module

The thermal interface also serves as the controls interface between the system modules. The thermal interface contains the logic control for maintaining the TSU. This involves energizing and controlling the output of the engine-generator in response to the sensed energy level of the TSU. Since the CHP system is intended to be compatible with various HVAC and DHW systems, its controls interface with the other modules only applies to the control of the thermal fluid flow to/from the various modules. The load management controls (e.g., HVAC and DHW) are independent of the thermal interface controls, and would be under the supervision of independent controllers (e.g., thermostats and humidistats). The thermal interface control diagram is shown in Figure 18. 


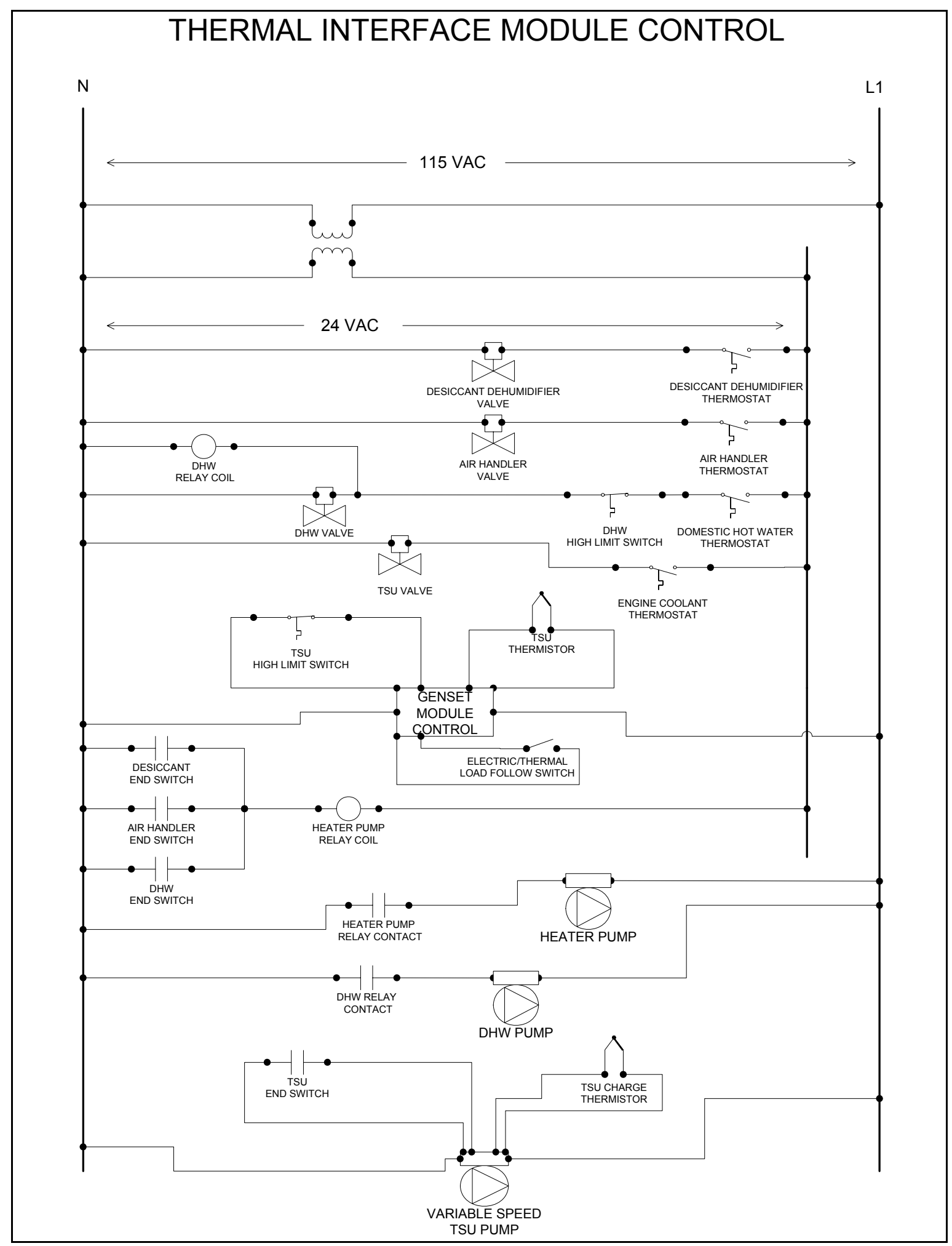

Figure 18. Thermal Interface Controls 


\subsubsection{Domestic Hot Water Heater}

Domestic hot water (DHW) heaters can be either instantaneous or storage-type. Instantaneous water heaters are generally more efficient, since they do not suffer the standby heat losses of storage-type water heaters. While they are popular in foreign countries and have made some penetration in the US, storage-type heaters predominate in this country. Arguably, the residential CHP system is ideally suited for an instantaneous water heater, since the heating-fluid-to-DHW inherently provides this function. However, to provide the large "dump" loads that a moderately large single family home is likely to experience, the heat exchanger would have to have a capacity of 5 or more GPM @ $70^{\circ} \mathrm{F}$ rise, which would require about $175,000 \mathrm{Btu} / \mathrm{hr}$. This would require a larger heat exchanger and a considerably larger pumping capacity than is needed for the $12.5 \mathrm{~kW}$ engine heat output. Accordingly, a storage type water heater is preferred.

The considerations regarding the type of storage tank and type of heat exchanger, internal or external, that apply to the TSU also apply to the DHW system. In this case, however, it is not necessary that the DHW tank have an independent (gas or electric) heater. There are numerous indirectly heated DHW tanks on the market that contain internal heat exchangers designed to be heated by boiler water. These generally contain a double-wall vented heat exchanger internal to the tank that would be piped to the heating fluid. Alternately, a less inexpensive indirectly heated tank similar to a standard electric water heater can be used. It differs from a conventional electric water heater in that it does not contain heating elements, and it contains an additional pair of supply/return fittings similar to those in the TSU tank, to enable domestic water to be circulated through the heat exchanger. In this case, a potable-water pump is required to circulate DHW between the tank and the heating-fluid-to-DHW heat exchanger. Any size tank can be specified, depending upon the needs and preferences of the homeowner. The thermal characteristics will be similar to those of the tanks in Table 18 .

The AO Smith Promax ${ }^{\circledR}$ XL circulating loop heat exchanger shown in Figure 19 can meet the heat transfer requirements for maintaining the DHW storage tank. This is a brazed plate-type heat exchanger that is intended for heat transfer between domestic hot water (primary fluid) and a secondary fluid.

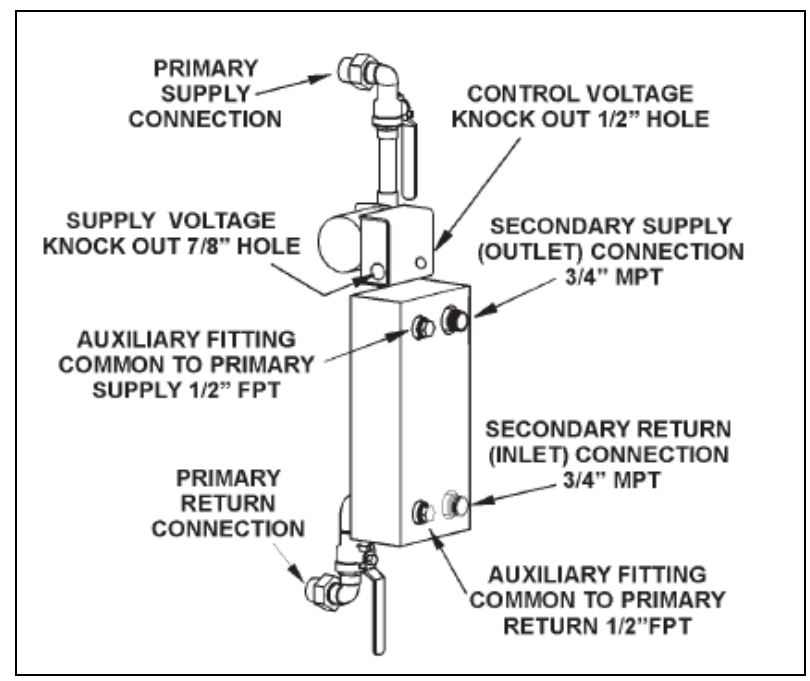

Figure 19. AO Smith Promax ${ }^{\circledR}$ XL circulating loop heat exchanger 
While Figure 19 shows it in a downflow configuration used for heating by DHW, it can equally be reversed for upflow heating of DHW. The heat exchanger is supplied with a primary pump and valves for mounting on the water heater. The model RXLD28 can transfer 70,000 Btu/hr from $4 \mathrm{GPM}$ of $180^{\circ} \mathrm{F}$ TSU water to $8 \mathrm{GPM}$ of $120^{\circ} \mathrm{F}$ DHW. Figure 20 shows its heat transfer as a function of TSU water temperature when heating water at an inlet temperature of $120^{\circ} \mathrm{F}$. This shows that a heat transfer rate of over $40,000 \mathrm{Btu} / \mathrm{hr}$ can be maintained down to a TSU supply temperature of about $155^{\circ} \mathrm{F}$. Over the range of TSU supply temperatures from $150^{\circ} \mathrm{F}$ to $180^{\circ} \mathrm{F}$ the return temperature ranges from $132^{\circ} \mathrm{F}$ to $145^{\circ} \mathrm{F}$. This high differential extends the useful energy storage capacity of the TSU.

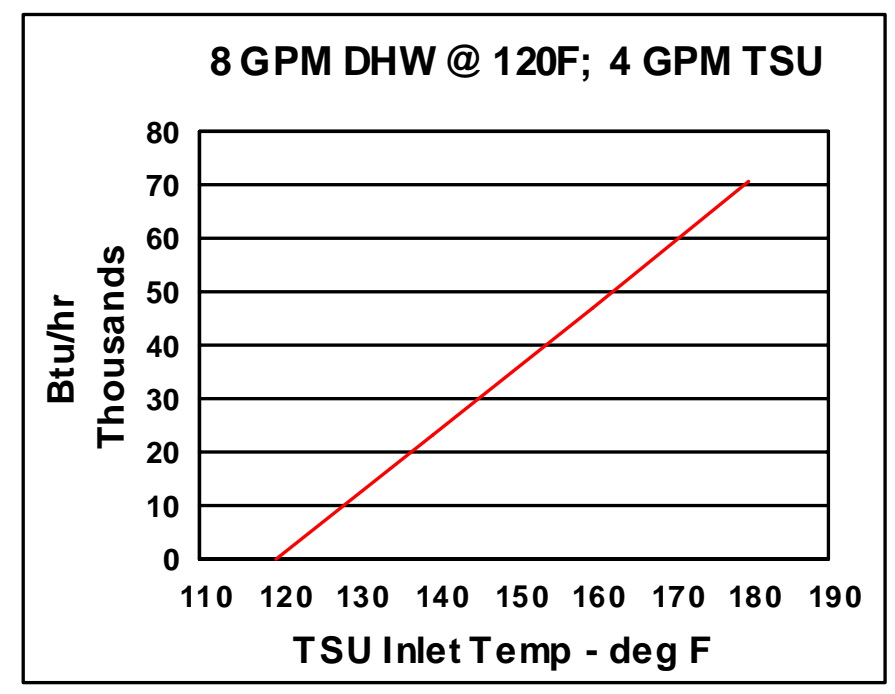

Figure 20. RXLD28 Heat Exchanger Performance

The TSU-DHW heat exchanger can be used to heat any type of storage vessel. Preferably the storage tank will be well-insulated with low standby losses. An electric water heater satisfies this requirement at an economical price. The inlet to the heat exchanger should draw from the bottom of the DHW storage tank. The tank return from the heat exchanger should be near or below the midpoint to enable the heated DHW return to mix with the tank contents to avoid stratification.

\subsubsection{Air Handler Module}

The air handler module consists of the air circulating blower, air conditioning evaporator, and the hydronic TSU-to-air heat exchanger coil. The TSU-to-air coil is similar to an air conditioning evaporator, except that its tubing contains hot water instead of refrigerant. Ideally, the TSU-toair coil would be contained within the air-conditioning air-handler enclosure together with the air conditioning evaporator. However, unless the air-conditioning manufacturer already offers this as a factory option, it would require enlarging the sheet metal enclosure of standard air conditioning air handlers, adding considerably to their expense. Moreover, there are numerous models of air handlers that would require this option. It is more practical and economical to offer TSU-to-air coils that would be installed in the ductwork downstream of the air-conditioning air handler. Such "hydronic duct heaters" can be supplied in a few sizes matched to the air-flow 
capacity of the air handler. Aftermarket hydronic duct heaters are also offered by several manufacturers as "booster heaters" or "reheat coils".

The required size of the hydronic coil is sensitive to the temperature of the heating fluid and the leaving air temperature. To avoid discomfort from cool drafts, a moderately warm leaving air temperature in the range of $110^{\circ} \mathrm{F}$ to $140^{\circ} \mathrm{F}$ is desirable. This requires about 600 to $1,000 \mathrm{cfm}$ to transfer $12.5 \mathrm{~kW}$.

A preliminary analysis of a hydronic heating coil having a face area of $2.5 \mathrm{sq}-\mathrm{ft}$ indicated that a 2-row coil using 3/8" tubing and 14 fins per inch should be capable of transferring $12.5 \mathrm{~kW}$ of heat at entering fluid temperatures above $150^{\circ} \mathrm{F}$. The results of the analysis are summarized in Table 20. At entering fluid temperatures between $150^{\circ} \mathrm{F}$ to $180^{\circ} \mathrm{F}$ a 2 -row coil can supply air at temperatures above $110^{\circ} \mathrm{F}$. At fluid temperatures below $140^{\circ} \mathrm{F}$, a 3-row coil is required, and the leaving air temperature drops below $110^{\circ} \mathrm{F}$ when the fluid temperature is below $130^{\circ} \mathrm{F}$.

Table 20. Example of Hydronic Coil Performance at 12.5 kW Output

\begin{tabular}{|l|c|c|c|c|}
\hline & \multicolumn{4}{|c|}{ Entering Water Temperature (F) } \\
& 180 & 150 & 140 & 130 \\
\hline Leaving Air Temp (F) & 142 & 112 & 118 & 107 \\
\hline Air Flow (SCFM) & 546 & 938 & 817 & 1,060 \\
\hline Blower Power (Watts) & 199 & 342 & 298 & 387 \\
\hline No. of Rows & 2 & 2 & 3 & 3 \\
\hline
\end{tabular}

This example illustrates the benefits of high thermal storage temperature. The required heat exchanger area is smaller, and warmer air temperatures can be provided. Less airflow is required, which reduces blower power. Useful heating can be attained over a relatively wide temperature swing, which maximizes the useful heat capacity for a given storage volume. Conversely, the use of domestic hot water as thermal storage at a temperature at or below $140^{\circ} \mathrm{F}$ would result in cooler leaving air temperatures and would permit a relatively small temperature swing of the TSU, requiring either a larger storage volume or greater engine cycling frequency.

The air-conditioning air handler would be sized in accordance with the cooling load of the house. Air handlers with variable-speed blowers are suitable for this application, since they can adapt to both the cooling and heating loads, and they can control the air flow over the evaporator coil to optimize latent cooling by the desiccant dehumidifier. The airflow performance of a 4-ton Trane air handler is shown in Table 21. At the design flow rate of 1600 CFM the blower power is approximately $600-650$ watts at an external static pressure of $0.5-0.7$ in WC. However, since the blower operates at reduced air flow for most of its duty, and since blower power varies approximately as the cube of air flow, the typical blower power is much lower.

Designs of hydronic duct heaters sized for 2 to 5 ton air handlers are shown in Table 22. 
Table 21. Air Flow Performance of Trane 4TEE3F49A Air Handler

\begin{tabular}{|c|c|c|c|c|c|c|c|c|c|c|c|c|}
\hline \multicolumn{13}{|c|}{ 4TEE3F49A AIR HANDLER AIRFLOW (CFM) VS. EXTERNAL STATIC PRESSURE WITH FILTER } \\
\hline \multirow{2}{*}{$\begin{array}{c}\text { OUTDOOR } \\
\text { UNIT SIZE } \\
\text { (TONS) }\end{array}$} & \multirow{2}{*}{$\begin{array}{l}\text { AIRFLOW } \\
\text { SETTING }\end{array}$} & \multicolumn{4}{|c|}{ DIP SWITCH SETTING } & & \multicolumn{6}{|c|}{ EXTERNAL STATIC PRESSURE } \\
\hline & & SW 1 & SW 2 & SW 3 & SW 4 & & 0.1 & .02 & 0.3 & 0.5 & 0.7 & 0.9 \\
\hline \multirow{3}{*}{3} & $\begin{array}{c}\text { LOW } \\
(350 \text { CFMTON) }\end{array}$ & ON & ON & OFF & ON & $\begin{array}{l}\text { CFM } \\
\text { watts }\end{array}$ & $\begin{array}{c}1050 \\
168 \\
\end{array}$ & $\begin{array}{c}1045 \\
192 \\
\end{array}$ & $\begin{array}{l}1040 \\
217 \\
\end{array}$ & $\begin{array}{l}1025 \\
265 \\
\end{array}$ & $\begin{array}{l}1005 \\
313 \\
\end{array}$ & $\begin{array}{c}1000 \\
362 \\
\end{array}$ \\
\hline & $\begin{array}{c}\text { NORMAL } \\
(400 \text { CFMTON) }\end{array}$ & ON & ON & OFF & OFF & $\begin{array}{l}\text { CFM } \\
\text { watts }\end{array}$ & $\begin{array}{l}1190 \\
215 \\
\end{array}$ & $\begin{array}{l}1195 \\
245 \\
\end{array}$ & $\begin{array}{l}1200 \\
274 \\
\end{array}$ & $\begin{array}{c}1200 \\
333 \\
\end{array}$ & $\begin{array}{l}1185 \\
392 \\
\end{array}$ & $\begin{array}{c}1175 \\
451 \\
\end{array}$ \\
\hline & $\begin{array}{c}\text { HIGH } \\
(450 \text { CFMTON) }\end{array}$ & ON & ON & ON & OFF & $\begin{array}{l}\text { CFM } \\
\text { watts }\end{array}$ & $\begin{array}{l}1355 \\
295 \\
\end{array}$ & $\begin{array}{c}1360 \\
326 \\
\end{array}$ & $\begin{array}{c}1370 \\
358 \\
\end{array}$ & $\begin{array}{c}1365 \\
421 \\
\end{array}$ & $\begin{array}{c}1345 \\
484 \\
\end{array}$ & $\begin{array}{l}1325 \\
547 \\
\end{array}$ \\
\hline \multirow{3}{*}{3.5} & $\begin{array}{c}\text { LOW } \\
(350 \text { CFMTON) }\end{array}$ & OFF & ON & OFF & ON & $\begin{array}{l}\text { CFM } \\
\text { watts }\end{array}$ & $\begin{array}{l}1200 \\
234 \\
\end{array}$ & $\begin{array}{l}1205 \\
264 \\
\end{array}$ & $\begin{array}{l}1215 \\
294 \\
\end{array}$ & $\begin{array}{c}1210 \\
354 \\
\end{array}$ & $\begin{array}{c}1205 \\
413 \\
\end{array}$ & $\begin{array}{c}1185 \\
473 \\
\end{array}$ \\
\hline & $\begin{array}{c}\text { NORMAL } \\
(400 \text { CFMTON) }\end{array}$ & OFF & ON & OFF & OFF & $\begin{array}{l}\text { CFM } \\
\text { watts }\end{array}$ & $\begin{array}{l}1405 \\
326\end{array}$ & $\begin{array}{c}1405 \\
366\end{array}$ & $\begin{array}{c}1405 \\
402 \\
\end{array}$ & $\begin{array}{c}1395 \\
462\end{array}$ & $\begin{array}{l}1390 \\
505\end{array}$ & $\begin{array}{c}1290 \\
532\end{array}$ \\
\hline & $\begin{array}{c}\text { HIGH } \\
(450 \text { CFMTON) }\end{array}$ & OFF & ON & ON & OFF & $\begin{array}{l}\text { CFM } \\
\text { watts }\end{array}$ & $\begin{array}{c}1580 \\
429 \\
\end{array}$ & $\begin{array}{c}1570 \\
458 \\
\end{array}$ & $\begin{array}{c}1560 \\
496 \\
\end{array}$ & $\begin{array}{c}1555 \\
573 \\
\end{array}$ & $\begin{array}{l}1550 \\
608 \\
\end{array}$ & $\begin{array}{l}1390 \\
547 \\
\end{array}$ \\
\hline \multirow{3}{*}{$4^{\star \star}$} & $\begin{array}{c}\text { LOW } \\
(350 \text { CFMTON) }\end{array}$ & ON & OFF & OFF & ON & $\begin{array}{l}\text { CFM } \\
\text { watts }\end{array}$ & $\begin{array}{l}1405 \\
326\end{array}$ & $\begin{array}{c}1405 \\
366\end{array}$ & $\begin{array}{c}1405 \\
402 \\
\end{array}$ & $\begin{array}{c}1395 \\
462\end{array}$ & $\begin{array}{c}1390 \\
505\end{array}$ & $\begin{array}{c}1290 \\
532\end{array}$ \\
\hline & $\begin{array}{c}\text { NORMAL } \\
(400 \text { CFMTON) }\end{array}$ & ON & OFF & OFF & OFF & $\begin{array}{l}\text { CFM } \\
\text { watts }\end{array}$ & $\begin{array}{c}1600 \\
444\end{array}$ & $\begin{array}{c}1595 \\
475\end{array}$ & $\begin{array}{l}1585 \\
515\end{array}$ & $\begin{array}{c}1590 \\
593\end{array}$ & $\begin{array}{l}1555 \\
623\end{array}$ & $\begin{array}{c}1390 \\
547\end{array}$ \\
\hline & $\begin{array}{c}\text { HIGH } \\
(450 \text { CFMTON) }\end{array}$ & ON & OFF & ON & OFF & $\begin{array}{l}\text { CFM } \\
\text { watts }\end{array}$ & $\begin{array}{l}1775 \\
635\end{array}$ & $\begin{array}{c}1780 \\
679\end{array}$ & $\begin{array}{c}1785 \\
701\end{array}$ & $\begin{array}{l}1740 \\
697\end{array}$ & $\begin{array}{l}1600 \\
656\end{array}$ & $\begin{array}{c}1450 \\
611\end{array}$ \\
\hline \multirow{3}{*}{5} & $\begin{array}{c}\text { LOW } \\
(350 \text { CFMTON) }\end{array}$ & OFF & OFF & OFF & ON & $\begin{array}{l}\text { CFM } \\
\text { watts }\end{array}$ & $\begin{array}{c}1565 \\
427\end{array}$ & $\begin{array}{c}1560 \\
458\end{array}$ & $\begin{array}{c}1550 \\
497\end{array}$ & $\begin{array}{c}1545 \\
577\end{array}$ & $\begin{array}{l}1540 \\
609\end{array}$ & $\begin{array}{c}1380 \\
539\end{array}$ \\
\hline & $\begin{array}{c}\text { NORMAL } \\
(400 \text { CFMTON) }\end{array}$ & OFF & OFF & OFF & OFF & $\begin{array}{l}\text { CFM } \\
\text { watts }\end{array}$ & $\begin{array}{c}1800 \\
652\end{array}$ & $\begin{array}{c}1800 \\
693\end{array}$ & $\begin{array}{c}1800 \\
714\end{array}$ & $\begin{array}{c}1740 \\
703\end{array}$ & $\begin{array}{c}1600 \\
651\end{array}$ & $\begin{array}{c}1450 \\
621\end{array}$ \\
\hline & $\begin{array}{c}\text { HIGH } \\
(450 \text { CFMTON) }\end{array}$ & OFF & OFF & ON & OFF & $\begin{array}{l}\text { CFM } \\
\text { watts }\end{array}$ & $\begin{array}{c}2020 \\
808\end{array}$ & $\begin{array}{c}1975 \\
801\end{array}$ & $\begin{array}{c}1930 \\
790\end{array}$ & $\begin{array}{c}1795 \\
760\end{array}$ & $\begin{array}{l}1665 \\
715\end{array}$ & $\begin{array}{l}1530 \\
658\end{array}$ \\
\hline \multicolumn{13}{|c|}{$\begin{array}{l}\text { NOTES: } \\
\text { 1. }{ }^{\star} \text { Factory setting } \\
\text { 2. At continuous Fan Setting: Airflow values are approximately } 50 \% \text { of listed value. } \\
\text { 3. For Variable Speed: low speed airflows are approximately } 30 \% \text { of listed values. } \\
\text { 4. With wet coil, filter in place. No heater installed. }\end{array}$} \\
\hline
\end{tabular}

Table 22. TSU-to-Air Heat Exchanger

\begin{tabular}{|c|c|c|c|c|}
\hline Air Flow Rate & SCFM & 1,200 & 1,600 & 2,000 \\
\hline Heating Capacity & $\mathrm{Btu} / \mathrm{hr}$ & 57,499 & 76,940 & 96,384 \\
\hline Entering Water Temperature & $\operatorname{deg} \mathrm{F}$ & \multicolumn{3}{|c|}{170} \\
\hline Entering Air Temperature & $\operatorname{deg} \mathrm{F}$ & \multicolumn{3}{|c|}{72} \\
\hline Leaving Air Temperature & $\operatorname{deg} F$ & \multicolumn{3}{|c|}{116} \\
\hline Face Velocity & $\mathrm{ft} / \mathrm{min}$ & \multirow{2}{*}{\multicolumn{3}{|c|}{$\frac{549}{047}$}} \\
\hline Air Pressure Drop & in WC & & & \\
\hline Water Flow Rate & GPM & \multicolumn{3}{|c|}{4} \\
\hline Fin Height & in & 15 & 20 & 25 \\
\hline Coil Width & in & \multicolumn{3}{|c|}{21} \\
\hline Coil Depth & in & \multicolumn{3}{|c|}{3} \\
\hline Fin Pitch & fpi & \multicolumn{3}{|c|}{12} \\
\hline Fin Thickness & in & \multicolumn{3}{|c|}{0.006} \\
\hline Tube OD & in & \multicolumn{3}{|c|}{0.375} \\
\hline Tube Pitch & & \multicolumn{3}{|c|}{ Staggered 1" x .866" } \\
\hline Water Pressure Drop & psi & 2.9 & 3.4 & 3.9 \\
\hline
\end{tabular}




\subsubsection{Air Conditioner}

The air conditioner is a conventional split system sized appropriately for the cooling load of the residence. Based upon the results of the market assessment and load simulations, the residence is likely to be $2,500 \mathrm{sq}-\mathrm{ft}$ or larger with the design cooling loads in the range of $3-5$ tons or more. For purposes of predicting the performance of the CHP system and comparing it to that of a conventional, non-CHP HVAC system, a cooling capacity of 4 tons $(48,000 \mathrm{Btu} / \mathrm{hr})$ is assumed. A typical high-efficiency system that would be installed in new construction is a Trane 4TTX6048B1 outdoor unit with a 4TEE3F49A indoor unit (air handler). This combination uses refrigerant R-410A, provides a SEER of 14, and has a variable-speed air-handler blower. The variable-speed feature can be used to vary the heat output of the hydronic heating coil to satisfy variable heating loads and to reduce parasitic power consumption.

In order to take maximum advantage of the thermally activated cooling provided by the desiccant dehumidifier, the sensible cooling ratio of the air conditioner should be maximized. Otherwise, whatever latent cooling is produced by the air-conditioner diminishes the load that can be handled by the dehumidifier. The sensible cooling ratio of the air conditioner increases as the evaporation temperature is increased, which occurs as the air flow is increased or as the size of the evaporator is increased. To take maximum advantage of desiccant cooling, the air conditioning system should be capable of modulating both its compressor speed and blower speed.

The cooling performance of a 4-ton Trane two-stage air conditioning system is shown in Tables 23 and 24 . This system provides the flexibility to vary the sensible cooling ratio as well as the total cooling capacity by varying compressor and blower flow. An example of how this affects power consumption and latent cooling is illustrated in Table 25. Consider constant sensible and cooling loads of 26,000 and $9,000 \mathrm{Btu} / \mathrm{hr}$, respectively, at a $95^{\circ} \mathrm{F}$ outdoor dry bulb with indoor dry-bulb and wet-bulb temperatures of $75^{\circ} \mathrm{F}$ and $63^{\circ} \mathrm{F}$, respectively. Using the performance data of Tables 23 and 24, we can estimate the average power consumption for the compressor at $2^{\text {nd }}$ stage/1600 CFM, and at $1^{\text {st }}$ stage/1200 CFM or $1350 \mathrm{CFM}$. At the second-stage operating point, the load factor is $76.4 \%$, and the average electric power consumption is $3.09 \mathrm{~kW}$. The air conditioner handles both sensible and latent loads. If the air conditioner operates at the $1^{\text {st }}$ stage and $1200 \mathrm{CFM}$, its load factor is $100 \%$, its average power consumption is $2.77 \mathrm{~kW}(89.5 \%)$, and it handles all but $1,700 \mathrm{Btu} / \mathrm{hr}$ of the latent load, leaving this amount to be handled by the desiccant dehumidifier'. By increasing the air flow to $1350 \mathrm{CFM}$, the sensible ratio of the evaporator is increased from 0.78 to 0.82 , the load factor is reduced to $93.5 \%$, and the EER of the air conditioner is increased from 11.99 to 12.23 . The net effect is to reduce the power consumption of the air conditioner from $2.77 \mathrm{~kW}$ to $2.59 \mathrm{~kW}(83.7 \%$ of baseline $)$, while increasing the desiccant latent load from $1,700 \mathrm{Btu} / \mathrm{hr}$ to $3,300 \mathrm{Btu} / \mathrm{hr}$.

Table 25 does not take into account the additional effect of the desiccant dehumidifier. When the dehumidified ventilation air is mixed with the indoor return air, the "indoor" wet bulb temperature will be reduced and the "indoor" dry bulb will increase. This further shifts the sensible/latent ratio towards sensible cooling.

${ }^{9}$ This example neglects any ad ditional sensible load that may be imposed by the op eration of the desiccant dehumidifier. 
Table 23. Trane 4-Ton Variable Capacity Air Conditioner Performance $-1^{\text {st }}$ Stage

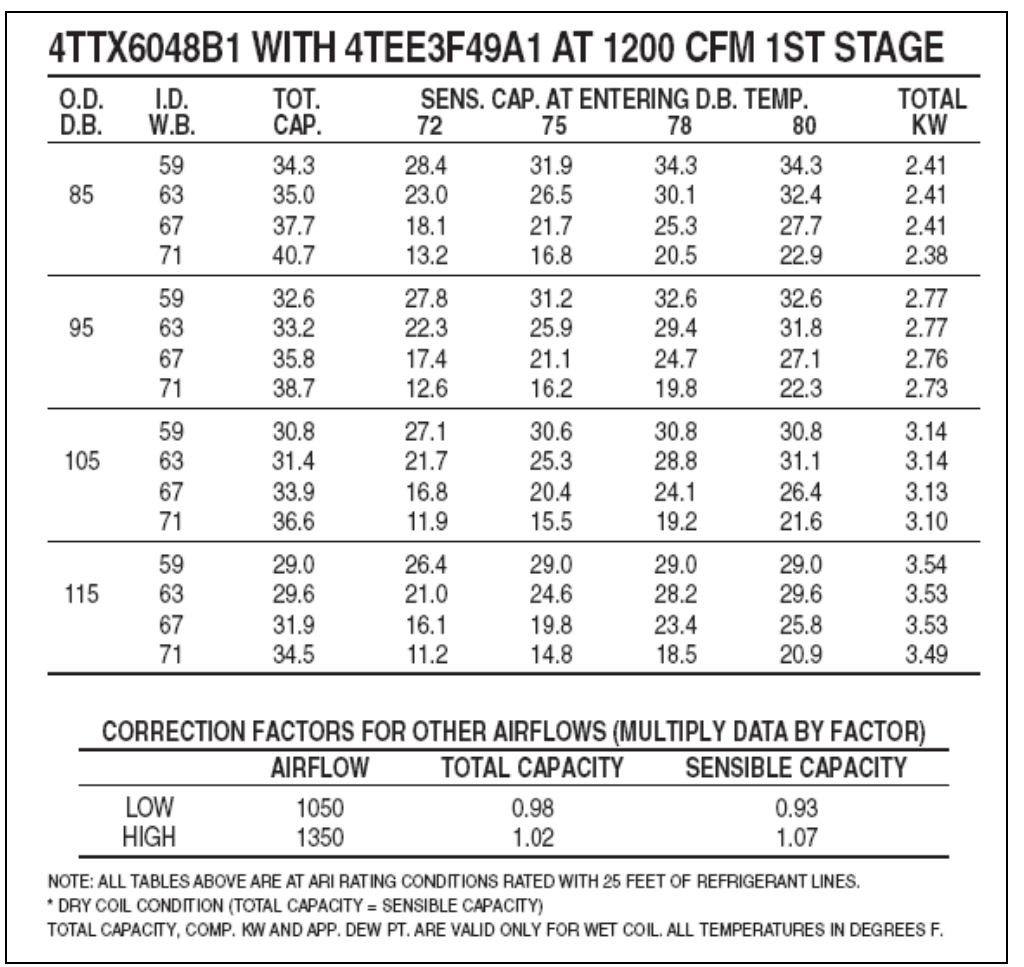

Table 24. Trane 4-Ton Variable Capacity Air Conditioner Performance $-2^{\text {nd }}$ Stage

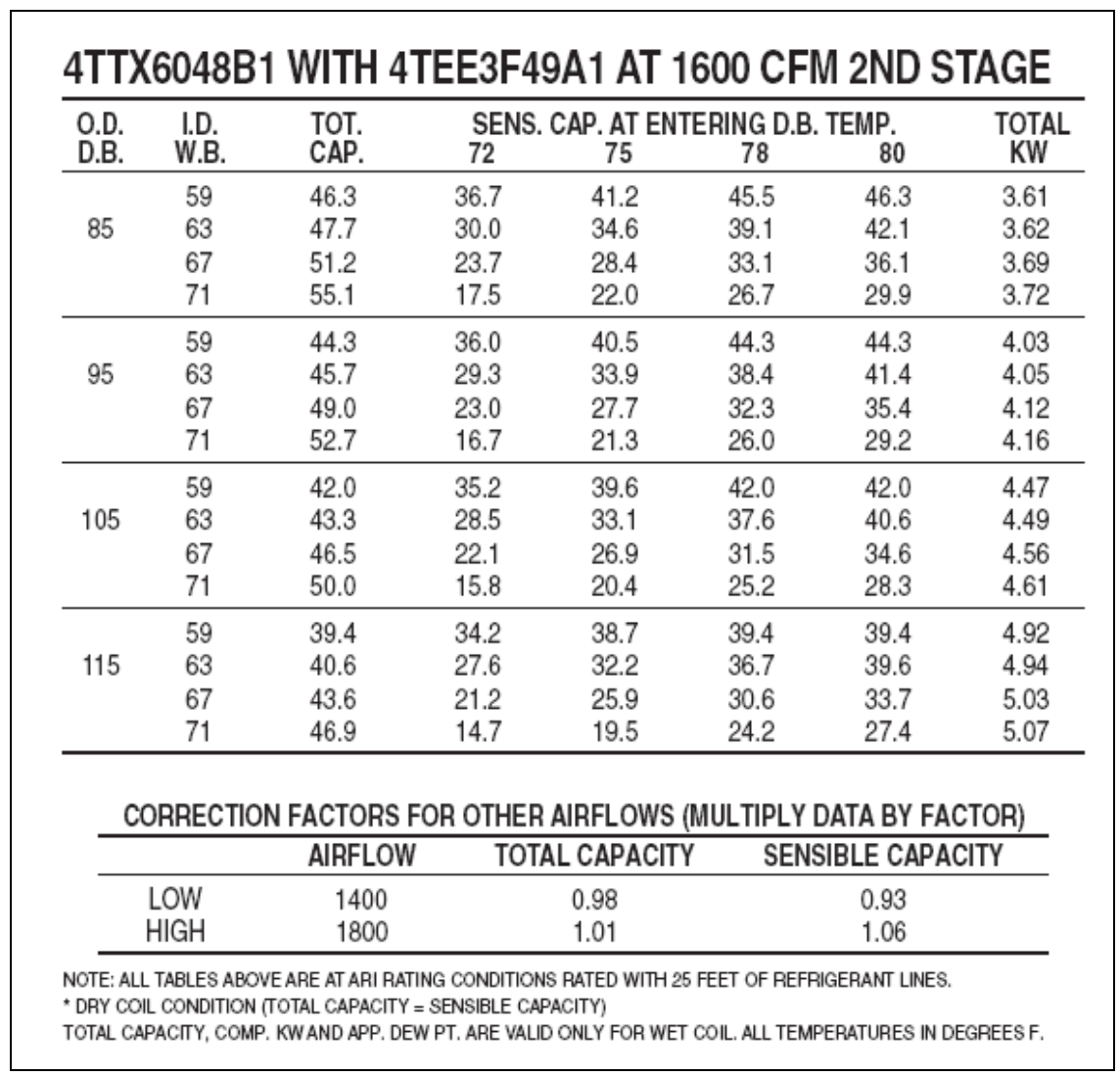


Table 25. Effect of Compressor Capacity and Airflow on Cooling Power

\begin{tabular}{|c|c|c|c|c|}
\hline \multicolumn{2}{|c|}{ Trane 4TTX6048B1 with 4TEE3F49A1 } & \multirow[b]{2}{*}{35} & \multirow[b]{2}{*}{35} & \multirow[b]{2}{*}{35} \\
\hline Total Cooling Load & $\mathrm{kBtu} / \mathrm{hr}$ & & & \\
\hline Sensible Load & $\mathrm{kBtu} / \mathrm{hr}$ & 26 & 26 & 26 \\
\hline Latent Load & $\mathrm{kBtu} / \mathrm{hr}$ & 9 & 9 & 9 \\
\hline Latent/Total Load & & $26 \%$ & $26 \%$ & $26 \%$ \\
\hline \multicolumn{5}{|l|}{ Cooling Capacity: } \\
\hline Outdoor Dry Bulb & $\operatorname{deg} \mathrm{F}$ & 95 & 95 & 95 \\
\hline Air Flow & CFM & 1600 & 1200 & 1350 \\
\hline Indoor Wet Bulb & $\operatorname{deg} \mathrm{F}$ & 63 & 63 & 63 \\
\hline Indoor dry Bulb & $\operatorname{deg} \mathrm{F}$ & 75 & 75 & 75 \\
\hline Total Capacity & $\mathrm{kBtu} / \mathrm{hr}$ & 45.7 & 33.2 & 33.9 \\
\hline Sensible Capacity & $\mathrm{kBtu} / \mathrm{hr}$ & 33.9 & 25.9 & 27.7 \\
\hline Total kW & $\mathrm{kW}$ & 4.05 & 2.77 & 2.77 \\
\hline Latent Capacity & $\mathrm{kBtu} / \mathrm{hr}$ & 11.8 & 7.3 & 6.2 \\
\hline Sensible Ratio & & 0.74 & 0.78 & 0.82 \\
\hline EER & Btu/W-h & 11.28 & 11.99 & 12.23 \\
\hline Load Factor & & $76.4 \%$ & $100.0 \%$ & $93.5 \%$ \\
\hline Desiccant Load & $\mathrm{kBtu} / \mathrm{hr}$ & 0.0 & 1.7 & 3.3 \\
\hline Avg A/C Power & $\mathrm{kW}$ & 3.09 & 2.77 & 2.59 \\
\hline & & $100.0 \%$ & $89.5 \%$ & $83.7 \%$ \\
\hline
\end{tabular}

\subsubsection{Mechanical Ventilation System}

The latest ASHRAE standard 62.2-2004 for "Ventilation and Acceptable Indoor Air Quality for Low-Rise Residential Buildings" sets minimum requirements for ventilation in single-family residential buildings. In most cases, the standard requires a minimum of 0.35 air-changes per hour $(\mathrm{ac} / \mathrm{h})$, including mechanical and natural ventilation. With some exceptions, most residences are required to have mechanical whole-house ventilation. The minimum mechanical ventilation rate for homes in the $2,500-4,500 \mathrm{sq}-\mathrm{ft}$ range is $75-90 \mathrm{cfm}$. In hot, humid climates mechanical exhaust systems may not exceed $7.5 \mathrm{cfm}$ per $100 \mathrm{sq}-\mathrm{ft}$, and in very cold climates (> 9,000 heating degree-days), mechanical supply systems may not exceed $7.5 \mathrm{cfm}$ per $100 \mathrm{sq}-\mathrm{ft}$. These limitations are to prevent humid air from being drawn/forced into cooler insulation in the exterior walls where it can condense or freeze.

A 3,000 sq- $\mathrm{ft}$ house with a volume of $24,000 \mathrm{cu}-\mathrm{ft}$ requires a minimum continuous ventilation of $140 \mathrm{cfm}$ to satisfy these requirements. If this air is unconditioned, it can add substantially to the space-conditioning load of the house, as well as possibly increasing discomfort. Without mechanical ventilation, air infiltrates into a building, and an equal amount of air exfiltrates to maintain a mass balance. The amount of infiltration depends on the envelope leakage area, and on the outdoor and indoor ambient conditions. Rates of infiltration vary widely, but newer, tighter homes typically experience $0.5 \mathrm{ac} / \mathrm{h}^{10}$

\footnotetext{
${ }^{10} 2001$ ASHRAE Handbook - Fundamentals, p. 26.16.
} 
The proposed mechanical ventilation system will minimize the infiltration of unconditioned air by supplying most or all of the ventilation requirement by means of a mechanical supply system. By mechanically supplying conditioned ventilation air at a rate comparable to the amount of naturally infiltrating air, the pressure in the building is increased, which blocks or diminishes the amount of unconditioned infiltration. Generally, the effect is not one for one. A widely used estimate $^{11}$ of the combined mechanical/infiltration flow is:

$$
\mathrm{Q}_{\mathrm{comb}}=\mathrm{Q}_{\mathrm{bal}}+\left[\mathrm{Q}_{\text {unbal }}^{2}+\mathrm{Q}_{\text {infiltration }}\right]^{1 / 2}
$$

By providing an amount of (unbalanced) mechanical supply flow equal to the amount of natural infiltration, the total ventilation increases by $41 \%$, but the infiltration is reduced by $59 \%$. Accordingly, a 3,000 sq- $\mathrm{ft}$ house $(24,000 \mathrm{cu}-\mathrm{ft})$ with $0.5 \mathrm{ac} / \mathrm{h}$ of natural infiltration should require $200 \mathrm{cfm}$ of mechanical supply ventilation in order to reduce its infiltration by $59 \%$, resulting in a total ventilation rate (mechanical plus infiltration) of $283 \mathrm{cfh}$.

\subsubsection{Desiccant Ventilator}

In most parts of the US, the ambient air which ventilates a conditioned space carries a disproportionate amount of humidity load. In a residence, typically nearly $100 \%$ of the humidity load enters from outside air, whether through ventilation or through infiltration. Neutralizing this load should allow the electric cooling device to operate to produce predominantly sensible cooling. This could allow raising evaporator temperatures and would improve the energy efficiency of the cooling device.

In order to neutralize this, the fresh air must be preconditioned and infiltration should be reduced or preferably eliminated. A residence of the size under consideration typically needs about 200 cfm of fresh air for occupant health and comfort. Bringing in this amount through a pretreatment subsystem does not necessarily eliminate infiltration because of leakage and pressure variations within the residence.

Preconditioning ventilation air, in contrast to bringing in raw outdoor ventilation air reduces the enthalpy of the mixed air stream brought to the cooling coil and thereby reduces the load on the air conditioner. Because of the mode in which it is operating, this unit principally produces latent cooling, making it suitable for relatively humid southeastern US climates.

The ventilator designed for the micro-CHP application provides $200 \mathrm{cfm}$ of air that is dehumidified by the desiccant unit to pressurize the conditioned space, forcing air to exfiltrate through any paths available, such as window frames, doorway clearances, etc. In its basic configuration, no exhaust air is brought to the unit. As will be discussed further in this section, the option of ducting exhaust air through the ventilator can improve the cooling capacity and efficiency of the unit above its basic performance.

The desiccant ventilator layout is shown in Figure 21.

${ }^{11} 2001$ ASHRAE Handbook - Fundamentals, Chapter 26, eqn. (43). 


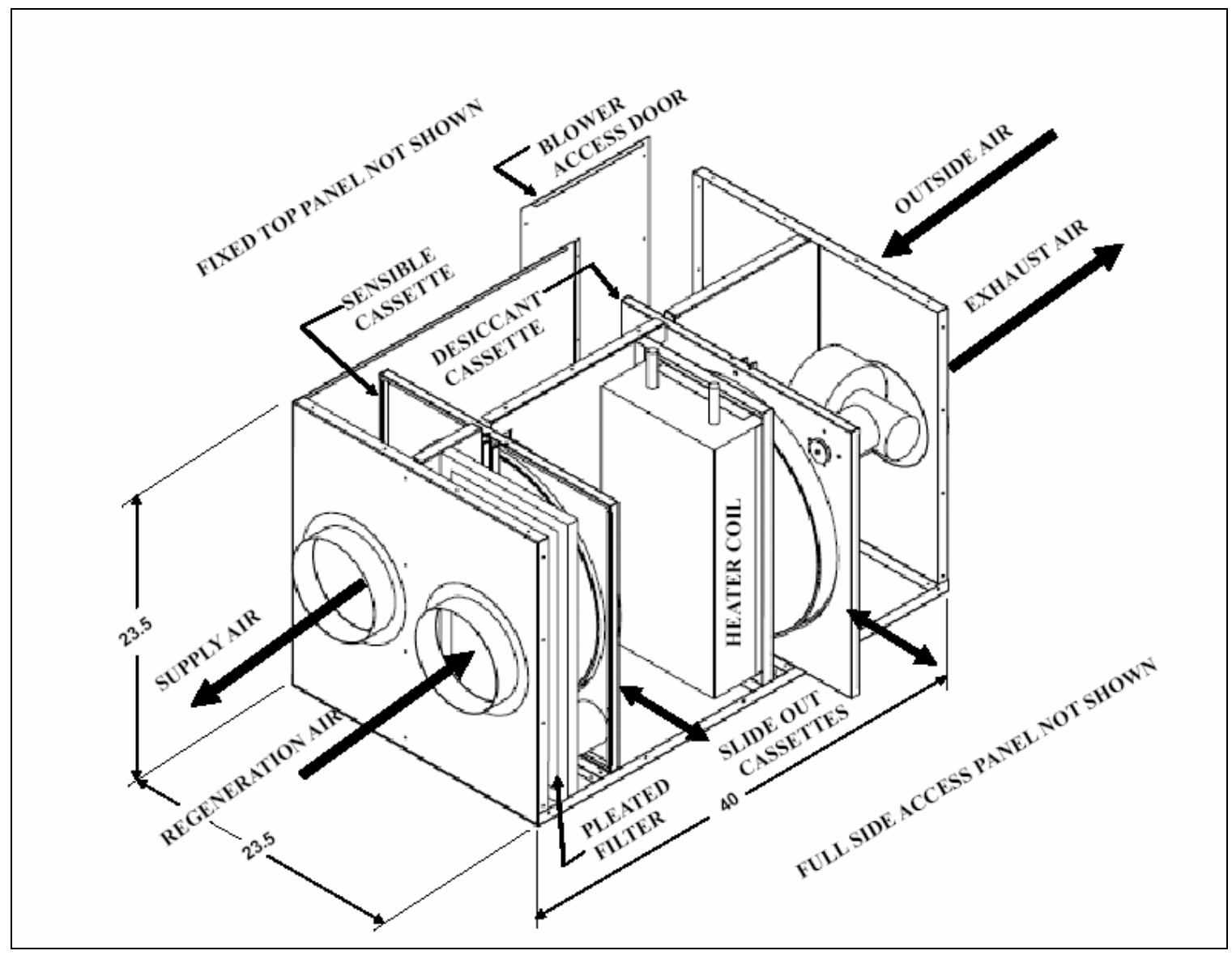

Figure 21. Desiccant Subsystem

Two air streams are used in a desiccant ventilator. One is fresh air that is dried for delivery to the air handler ("supply air"). The second air stream is used to cool the delivered air and regenerate the desiccant in the desiccant wheel ("regeneration air").

There are two wheels in this system. One wheel is a sensible-only heat recovery wheel ("sensible wheel"). It acts as a sensible heat exchanger between the regeneration air and the supply air. The second contains desiccant and is intended to dry the outside air ("desiccant wheel"). The processes are as follows.

Moist supply air enters the desiccant wheel, is dried, and heated in a roughly constant enthalpy process. The desiccant adsorbs water from the air in this process. The supply air emerges from the desiccant wheel and enters the sensible wheel, which cools it before it enters the air handler. Regeneration air first enters the sensible wheel and absorbs the heat that was removed from the supply air. Preheating the regeneration air in this way reduces the amount of energy required to heat the air to a temperature at which it can effectively regenerate the desiccant in the desiccant wheel. The regeneration air next passes through the hydronic heating coil which heats it to the regeneration temperature. The hydronic coil is heated by hot water supplied from the TSU. Finally, the heated air passes through the desiccant wheel, where it evaporates the water that had 
been adsorbed from the supply air, thereby regenerating the desiccant. The desiccant wheel is now dry and ready to adsorb water from the moist outdoor supply air stream.

The dimensions of the desiccant unit are shown in Figure 21. Contained within the box are the two aforementioned wheels, the heating coil, two blowers, motor drives for the wheels, air filters, and insulation around the heated area. The design reflects a tradeoff between cost and performance. Larger wheels are more efficient but more expensive. Both wheels have been selected to be 19" in diameter and 2" deep. The desiccant wheel will rotate at $100 \mathrm{rph}$, while the speed of the sensible wheel will be about $50 \mathrm{rpm}$. This design is based upon a heavier-than-normal desiccant coating of about $30 \%$ of the weight of the core. Currently such desiccant wheels have a coating density of about $14 \%$ or less. The heavier coating is expected to improve the performance by about $20 \%$, but will require some development in the next phase to assure its integrity and durability.

The desiccant wheel is regenerated by a copper-tube/aluminum-fin coil similar to the air-handler air-heating coil, located between the sensible heat wheel and the desiccant wheel. The regeneration heat exchanger is designed to heat the regeneration air to within $10^{\circ} \mathrm{F}$ of the TSU fluid temperature, while cooling the TSU fluid by $40^{\circ} \mathrm{F}$ in order to minimize engine cycling. A design specification for this heat exchanger is shown in Table 26.

Table 26. Desiccant Regeneration Heat Exchanger

\begin{tabular}{|c|c|c|}
\hline Air Flow Rate & SCFM & 200 \\
\hline Heating Capacity & $\mathrm{Btu} / \mathrm{hr}$ & 15,085 \\
\hline Entering Water Temperature & $\operatorname{deg} \mathrm{F}$ & 180 \\
\hline Entering Air Temperature & $\operatorname{deg} F$ & 100 \\
\hline Leaving Air Temperature & $\operatorname{deg} \mathrm{F}$ & 169 \\
\hline Face Velocity & $\mathrm{ft} / \mathrm{min}$ & 168.4 \\
\hline Air Pressure Drop & in WC & 0.10 \\
\hline Water Flow Rate & GPM & 0.76 \\
\hline Fin Height & in & 9.0 \\
\hline Coil Width & in & 19 \\
\hline Coil depth & in & 4.0 \\
\hline Fin Pitch & fpi & 19 \\
\hline Fin Thickness & in & 0.006 \\
\hline Tube OD & in & 0.375 \\
\hline Tube Pitch & \multicolumn{2}{|c|}{ Staggered 1" x .866" } \\
\hline Water Circuits & & 2 \\
\hline Water Pressure Drop & psi & 1.0 \\
\hline
\end{tabular}




\section{Performance}

The cooling effect of the desiccant ventilator is calculated as the total enthalpy reduction of the outdoor air. The energy consumption consists principally of the heat required to heat the regeneration air and the electricity used to power the fans and wheel drives. The COP is calculated as the ratio of cooling effect/regeneration heat.

In the baseline design, both air streams consist of $200 \mathrm{cfm}$ of outdoor air. The design condition assumes a fairly warm and humid $95 \mathrm{~F}$ and 119 grains/lb humidity, for a dew point of about 74 F. This is a typical design point for a location like Jacksonville, Florida. Nominal regeneration air temperature of the coil is $170 \mathrm{~F}$. At baseline conditions, the cooling capacity is about 0.5 tons, almost entirely latent, and the COP is about 0.82 . This mode produces no sensible cooling of the supply air; that is, all of the cooling is latent cooling.

Performance charts for the unit are shown as Figures 22 for cooling capacity and 23 for COP. Outdoor air is indicated for regeneration to contrast with later figures.

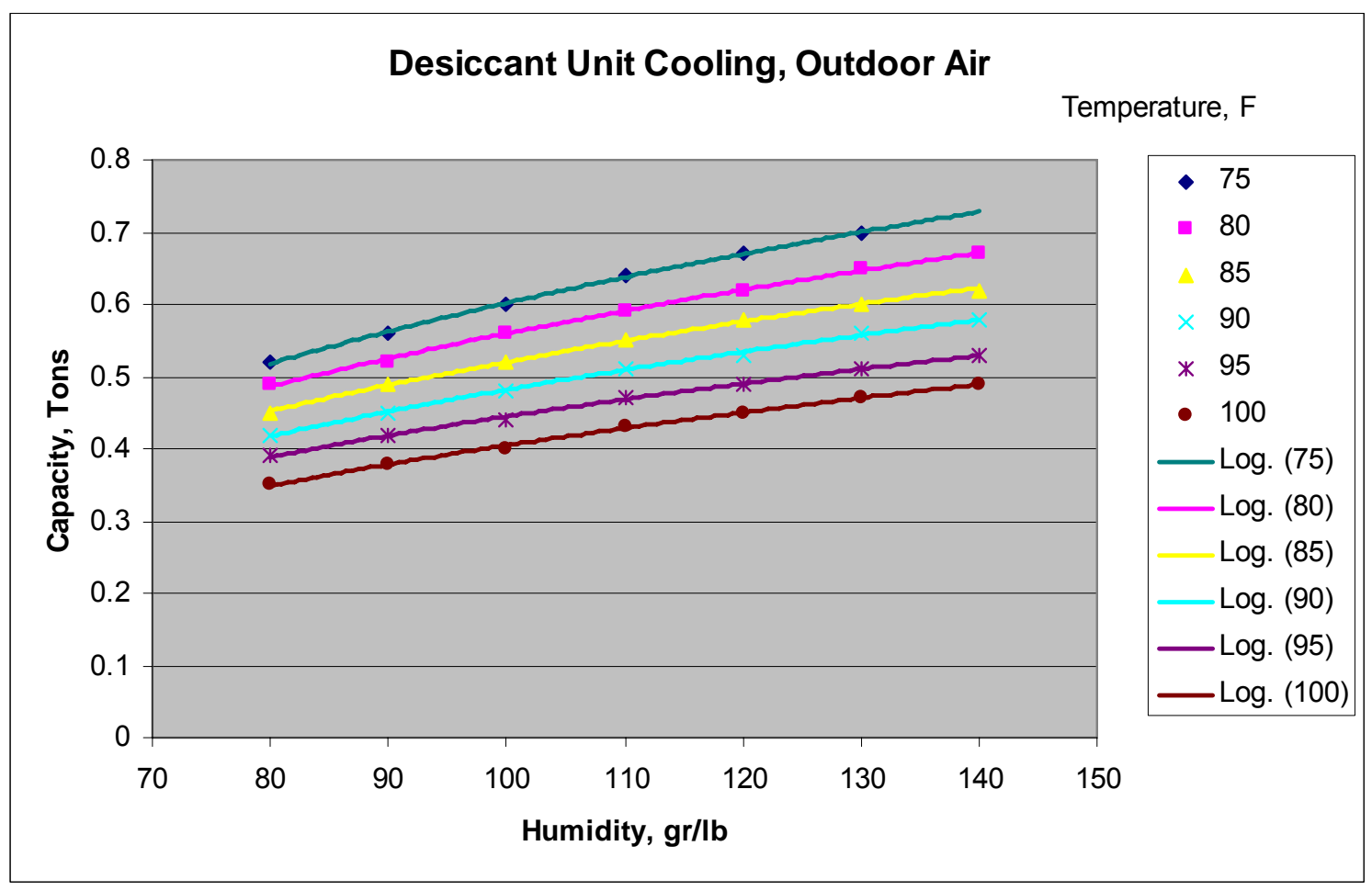

Figure 22. Desiccant Cooling Capacity - Basic Configuration 


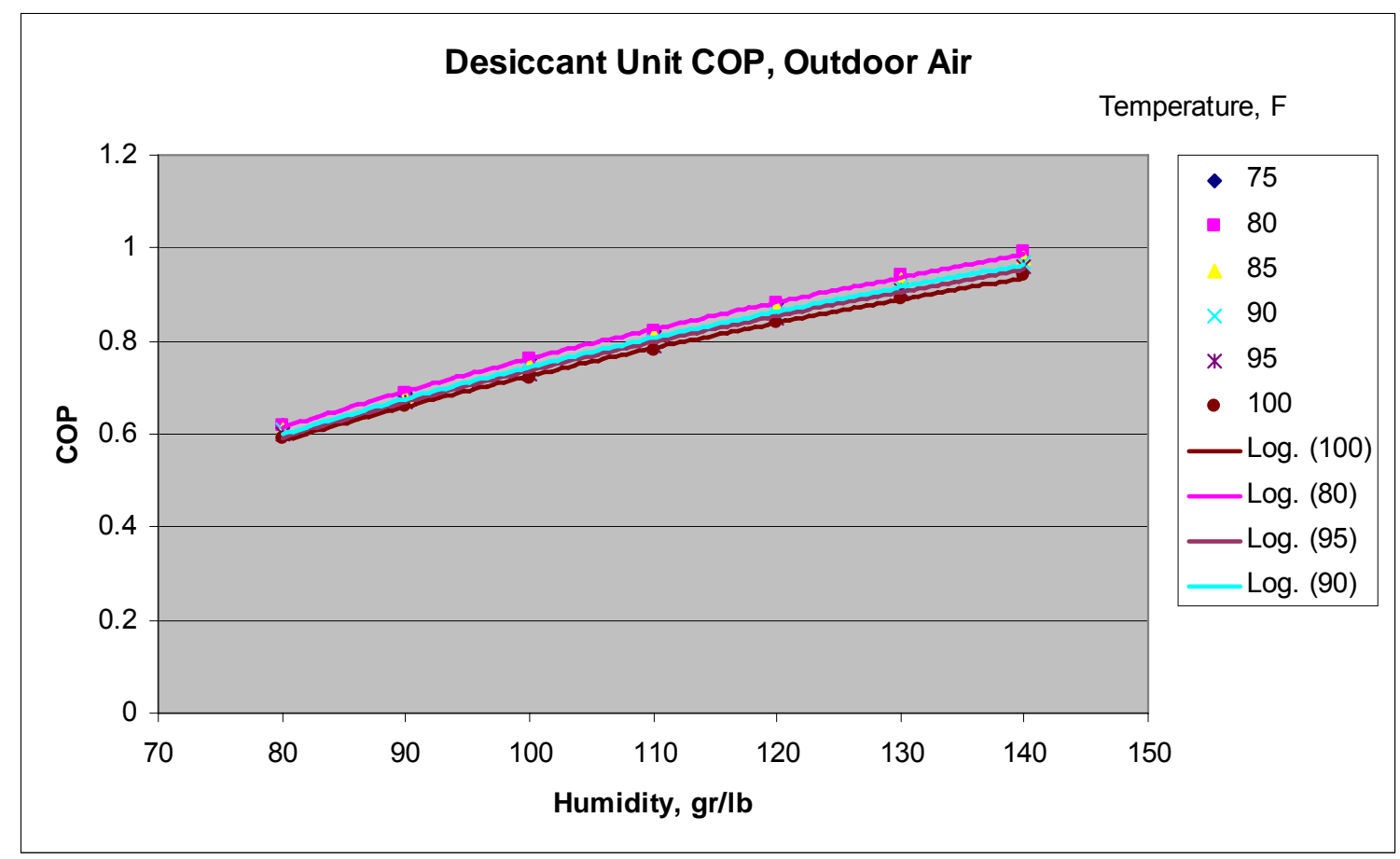

Figure 23. Desiccant COP - Basic Configuration

In this mode, both COP and cooling capacity improve as outdoor humidity rises. Cooling capacity also improves as outdoor temperature drops.

The previously cited performance is for the least efficient application of the desiccant ventilator. Two alternate modes of operation that provide superior performance can also be considered. The first alternative involves the same unit but with house exhaust air used for the regeneration air stream. If the house is tight, as new construction is more likely to be, then the need to pressurize the house is reduced. The regeneration air stream can also be a mix of exhaust air and outdoor air, if some pressurization is desired. At the design conditions, the cooling capacity would increase to 0.9 tons and the COP would be 1.72 . This mode produces about $30 \%$ of its capacity as sensible cooling of the ventilation air.

Performance charts for the unit with $100 \%$ exhaust air for regeneration are shown as Figures 24 for cooling capacity and 25 for COP. Exhaust air is indicated for regeneration to contrast with earlier figures. 


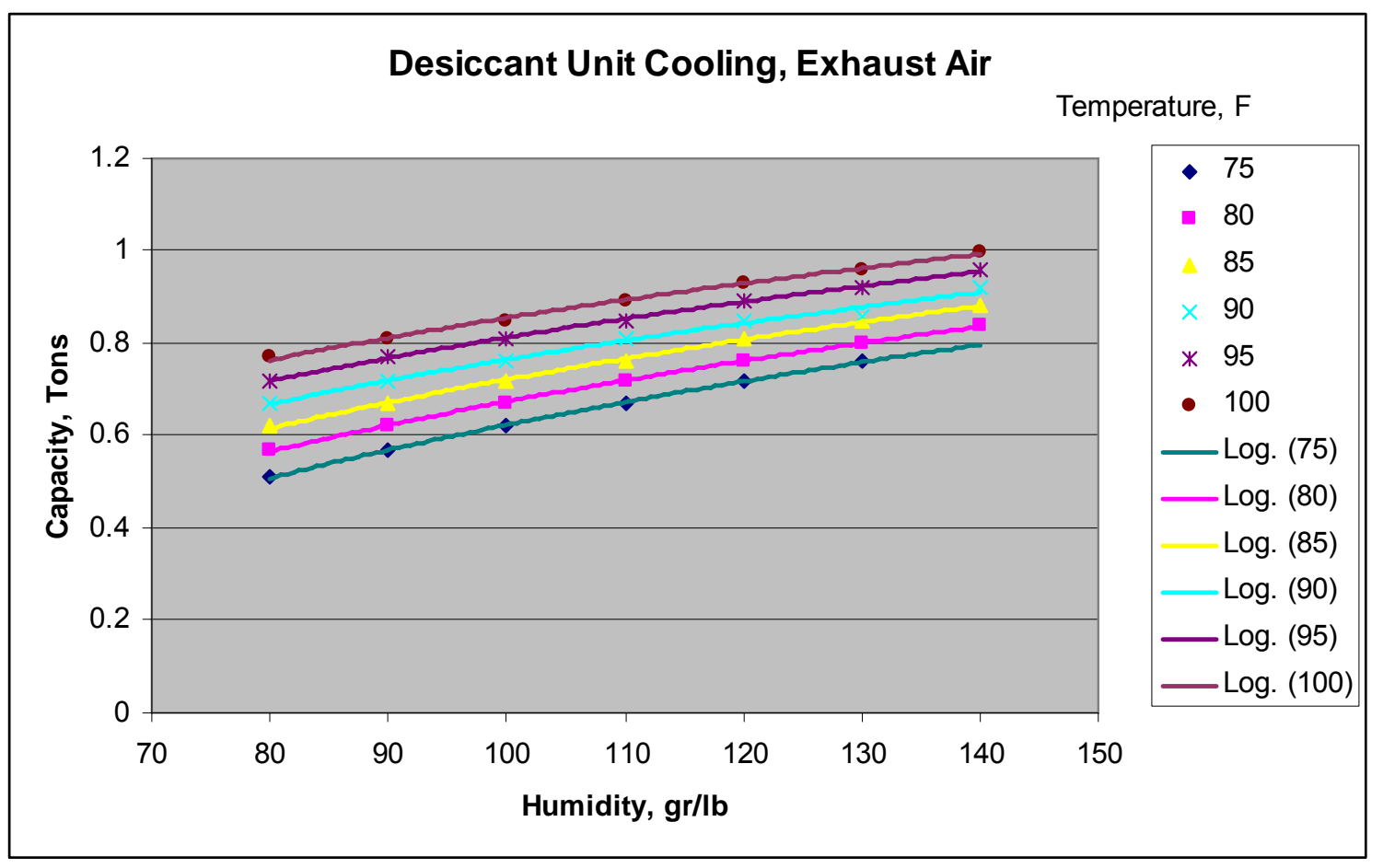

Figure 24. Desiccant Cooling Capacity - Indoor Exhaust Configuration

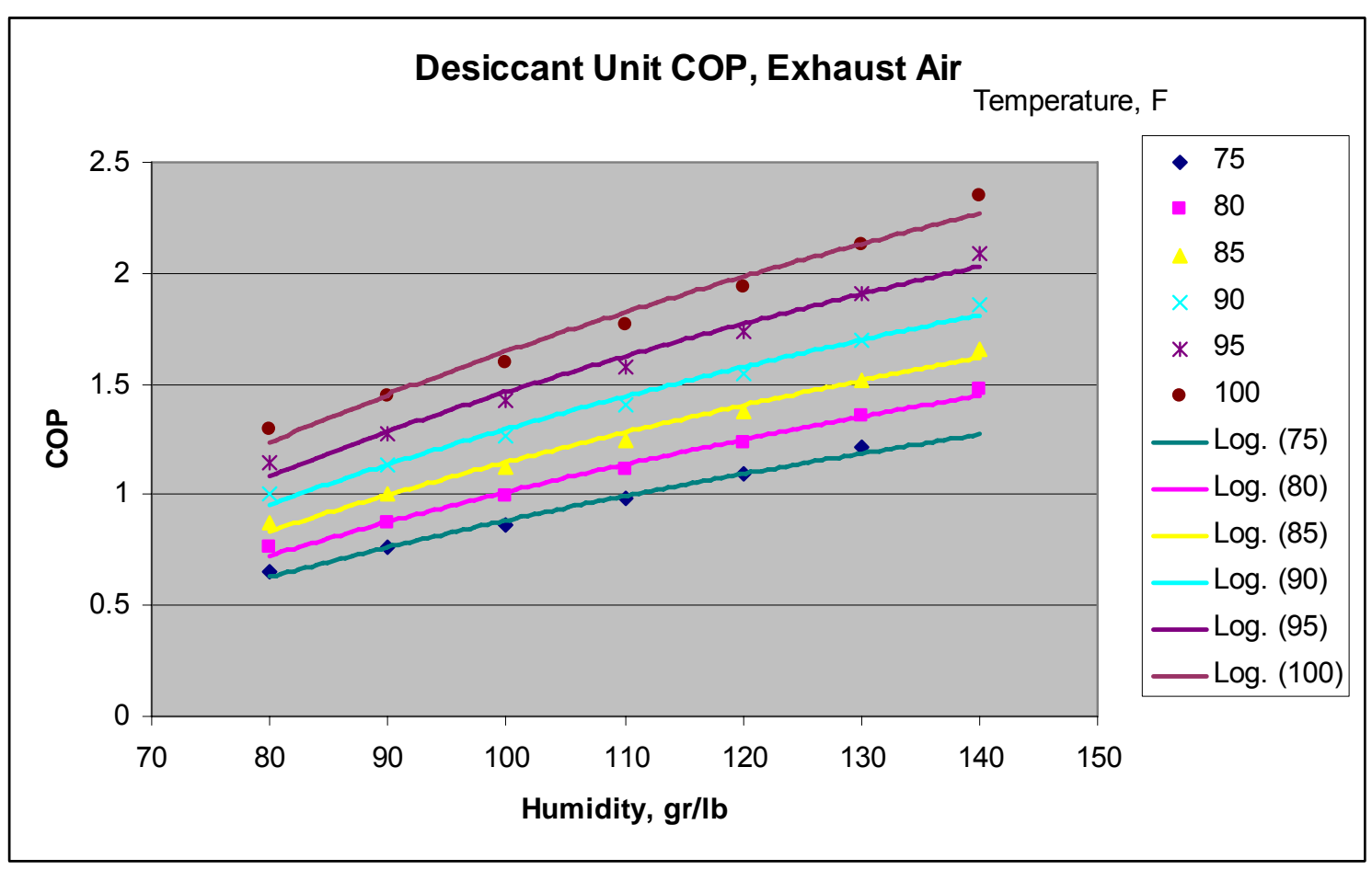

Figure 25. Desiccant COP - Indoor Exhaust Configuration 
Both cooling capacity and COP rise as either outdoor temperature or outdoor humidity rise. This is a desirable characteristic, since the cooling capacity increases as the need increases.

Comparing the values for COP and cooling capacity using exhaust air versus outdoor air for the regeneration air stream clearly shows the advantage of using the indoor air for regeneration. This takes advantage of the cooling provided by the air conditioner by not wasting its effect by exfiltrating cooled air through leakage pathways. Capacities increase by about $50 \%$ and COP's can reach quite attractive values.

Other options that can be considered to increase thermally activated cooling are increasing the total ventilation air flow and possibly using a mixture of exhaust and outdoor air for regeneration. This would provide a more healthy indoor air quality and utilize more of the engine heat. However, such a unit would be more expensive.

Another option is to place a direct evaporative cooler on the exhaust air before the sensible wheel. This will further reduce the temperature of the supply air and will increase the cooling capacity of the unit. It will add to the size, cost, and complexity of the package and the use of water and added attendant maintenance requirements are disadvantages. As an example of the level of improvement that could be expected, considering the exhaust air option for regeneration, the design point performance would increase to a cooling capacity of 1.03 tons and a COP of 1.81. This can be compared to a capacity of 0.88 tons and a COP of 1.72 at that condition when not using evaporative cooling. Using outdoor air for regeneration, the cooling capacity would be 0.7 tons at a COP of 1.07. This can be compared to the baseline values without evaporative cooling of 0.5 tons at a COP of 0.82 .

The OEM price of the basic design is projected to be $\$ 961$ in quantities of 2000 per year and $\$ 836$ in quantities of 10,000 per year. This is the price to whoever markets the entire system, so a markup will need to be added. Assuming that the ventilator would be supplied with the microCHP system and that a $25 \%$ distributor markup would be applied, the contractor price is estimated to be $\$ 1,201$ to $\$ 1,045$. These prices are comparable to those of passive highefficiency heat-recovery ventilators used to recover heat from the exhaust air from a home.

One development issue to be addressed in Phase 2 is how to increase the desiccant loading on the substrate of the wheel core and still take advantage of the kind of low cost design which is typical of Airxchange wheels. The second is a more detailed consideration of the alternate operational modes/options to determine their cost/benefit in different locales and applications. The Phase I economic and energy consumption studies done so far have considered only the basic (i.e., outdoor regeneration air) configuration in which only the ventilation air is conditioned by the desiccant. More intensive desiccant cooling schemes that combine evaporative cooling with desiccant dehumidification of the primary (recirculating) air stream would utilize larger amounts of cogenerated thermal energy with greater energy efficiency.

In conclusion, a cost-effective design for a desiccant ventilator has been developed in this phase that makes effective use of recovered engine heat for space cooling. The basic configuration provides positive pressurization of the house, which minimizes infiltration of unconditioned air. 
Other configurations to be addressed in the second phase of this project can provide higher performance at somewhat greater cost.

\subsubsection{Controls}

The Ecopower system control is made up of four modules. These are:

- engine control module

- heat control module

- electric control module

- battery system module.

These modules are interconnected via a communication bus in a bi-directional mode.

A DC-DC converter that delivers constant voltage during all conditions supplies power for the system. The system battery is supported during running mode by a separate charging device driven from the generator output.

\section{Engine Control Module}

The engine control module design includes a microprocessor for all engine functions, inputs from the engine group and outputs to various control devices. Air/fuel and ignition maps are resident in the microprocessor to operate the engine at peak efficiency during a wide range of parameters. Engine air/fuel ratios can be controlled based on operating load to provide maximum output or to provide minimum fuel consumption.

Protections are programmed into the module microprocessor to check for all expected faults, i.e. low oil pressure, over temperature, etc. Additionally, self-diagnosis is performed on every power-up of the engine control to check for wire faults, defective devices, etc. Faults are logged into the microprocessor and also sent to indicators for alerting the operator.

\section{$\underline{\text { Heat Control Module }}$}

The standard Ecopower heat control module includes a second microprocessor to gather all inputs from the installation. Standard units allow for three zones of independent control; options allow for up to 24 independent zones. Storage tank temperature is monitored in three levels to allow for tank stratification. Outputs from this module provide for control of circulation pumps in either digital or analog modes, solenoid operation, indicators for the operator/user, data logging to track thermal output and operating conditions, interconnection to the other modules, and communication with separate devices within the overall system (additional boilers/heaters, air handling equipment, etc.).

Selection can be made to thermal load follow or electric load follow. In the preferred thermal load following mode while connected to the grid, excess electric power is exported to the grid. When thermal following in off-grid (islanded) mode, excess electric energy is directed by this module to electric elements in the TSU storage tank. In an electric following mode, electric production has priority over thermal output. When all thermal loads are satisfied and the TSU is fully charged, excess heat is rejected outdoors through a liquid/air heat exchanger (radiator). In this way, operation is continuous and all electric loads are supported. 
A simple interface is used to communicate operation to the user via a display. Simple steps can be taken to program the desired temperatures and settings for normal use in all modes of operation. Detailed programming is only available to service technicians or the knowledgeable user.

The heat control module can be used as the overall CHP/HVAC supervisor, providing advanced HVAC and energy management features. Alternately, it can function solely as an internal load manager, responsive to external demand signals.

\section{Electric Control Module}

The Ecopower electric control module is designed to provide a stable power supply to the load as well as interface to and sell back excess power to the utility. A programmed 'sequence of events' allows this module to provide these functions. Input from the permanent magnet generator is rectified and sent to a DC bus. From that point, proprietary inversion software/componentry generates a high quality, low distortion waveform compatible with the existing grid supply and loads. Inputs from the other modules as well as monitored points in the electric pathway determine the operating conditions of the electric module. Outputs to the other modules and external control devices, i.e. relays, meters, displays, etc. provide information for the user and the utility when needed.

The present Ecopower electric control module is designed to manage grid connection/disconnection. The sequence of events for connecting/disconnecting to the grid is as follows.

1) Grid power is present and the machine is off (not generating due to no therm al load requirement or manual off by user).

2) Mechanical grid connection relay is open (not connected to grid power)

3) Signal becomes present calling for thermal output.

4) Engine is started by battery power and allowed to idle for 2 minutes. Output from generator goes nowhere. No load applied to engine.

5) Computer looks at grid input c onnections to determine if grid is present and stable. Usual scan for this state is 30 seconds (1,800 cycles).

6) If grid is present and stable, the $m$ echanical relay is closed and connected to the grid input. No current is allowed to flow (zero power generated).

7) The grid frequency is captured and used to begin allowing current flow at the $m$ atching frequency. Engine throttle is opened to match the power mechan ically to the generator load (typically at 2,100 rpm ) until the throttle is completely open. Typical output at this rpm is 1800-1900 watts or $2+$ HP.

8) The engine rpm is adjusted up or down to deliver the required thermal output being called for by the control. All power produced is available to the current loads on the line. If the house load is ligh $\mathrm{t}$, excess power is push ed back in to the grid by raising the generated voltage slightly above grid supply voltage.

9) A proprietary circuit on the control continually checks for the presence of the grid.

10) If the grid falters or drops away, the relay contacts open, the throttle is closed to idle position, and electric generation stops immediately. 
11) The engine enters a 'cool-down' cycle for 3 minutes.

12) If, during that 3-minute cycle, the grid returns, the system returns to ste $p 5$ with a note that the grid has fallen one time.

13) If the system passes step 5, the seq uence begins to move forward from there toward norm al operation.

14) If the system fails at step 5, the fallen grid counter is incremented up by one.

15) Step 5 is tried again.

16) If step 5 cannot pass within the 3-m inutes, the engine shuts off and the system resets after 20 minutes. This also occurs if the fallen grid counter reaches 4 .

17) If the system is operating norm ally, the engine enters the "cool-down' cycle on a "STOP" command from the user or a shut-down comm and from the system when the thermal storage system reaches the m aximum set temperature. This will happen if the unit $m$ odulates down fully and the output at that level is above the thermal usage level.

18) The system returns to step 1 and begins again.

The ability to operate as a Continuous Backup Power source is an essential feature of the proposed micro-CHP system. To provide this capability, the system must be able to operate in parallel with the electrical grid, isolated from the grid (islanded mode), and be automatically disconnected from the grid when the grid is disabled. The ability to provide these features efficiently and at an economical price are key innovations of the Marathon micro-CHP generator.

The previous sequence only provides for generator operation in parallel with the grid or for disconnection in the event of failure of the grid. Additional control functions are required to enable off-grid operation. In the grid connected configuration, the Micro-CHP outputs a DC buss voltage. The inverter system takes the raw DC Buss voltage and chops it into a PWM (Pulse Width Modulated) waveform. This waveform is reconstructed in a stable frequency, independent of load or engine speed. Excess/insufficient power is exported/imported to/from the grid. The simplified diagram below illustrates this configuration:

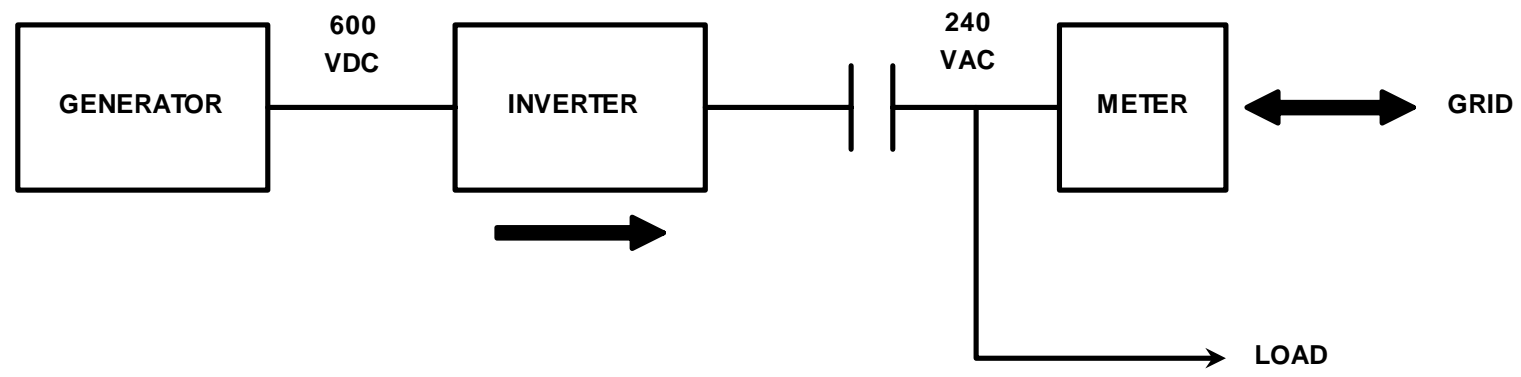

Figure 26. Grid-Connect Power Conditioning

Islanding requires storage batteries to provide a peaking capability and to supply house power during periods when the generator is idle. Generally the addition of islanding requires considerable additional hardware that makes this impractical except for very expensive systems. Marathon has developed an inexpensive proprietary system (patent to be applied for) that enables the existing (i.e., grid-mode) DC-to-AC inverter to be supplied by power either from the DC generator or from storage batteries. The batteries are kept charged by a trickle charger when in the grid-connected mode, and are charged by the generator when in the islanded mode. The cost 
of islanding will add approximately $\$ 4,000$ to the installed cost of the system, which includes about $\$ 2,000$ for batteries.

For the system to operate in parallel or islanded from the grid, the inverter can be made to be regenerative. When the generator is operating, the bi-directional regenerative inverter powers the load and/or exports surplus power to the grid, as illustrated in Figure 27. In this case the DC buss is used to charge storage batteries which will power the local load while the enginegenerator is idle, supplying AC power to the load through the inverter.

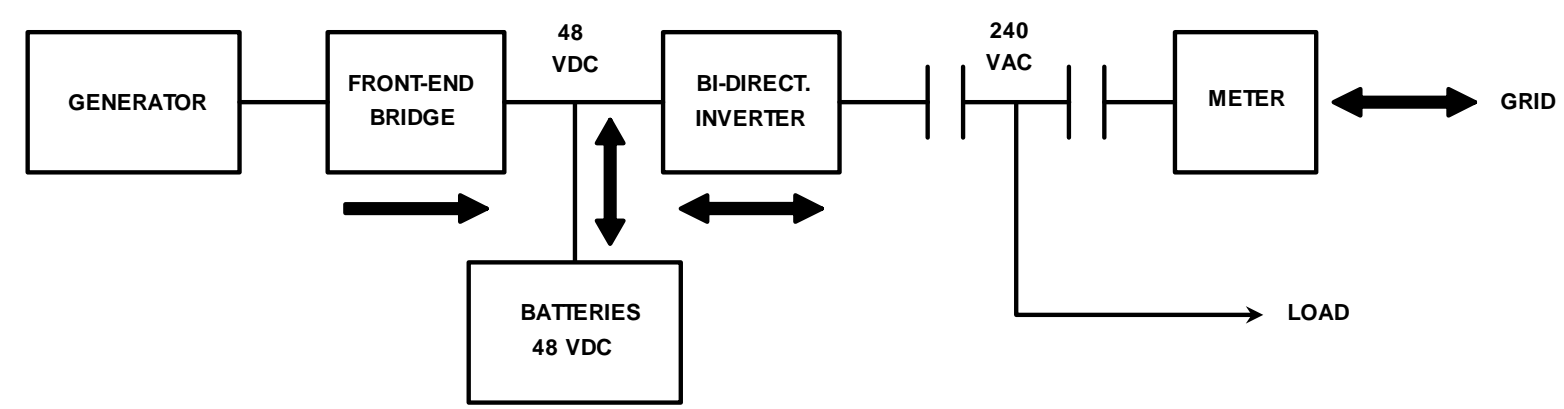

Figure 27. Continuous Backup Power Conditioning

Battery Control Module

The battery control module is designed to monitor and control input to the battery pack and output from the battery pack when in use. The battery pack is used as a storage device for electric energy and is used to support the loads of the system when the utility grid is not available. In normal operation, the battery pack is charge controlled by the module and maintained over time through exercise and replenishment. Pre-programmed software code is used to identify the battery type (lead-acid, gel, nickel cad, etc.) and provide a charge/discharge routine that extends the service life of the battery. This routine includes provision for equalization, temperature compensation, and adaptive cycling.

Inputs and outputs monitor and $\log$ the operation of the entire battery pack as well as individual batteries within the pack. Options allow for additional packs and automatic bypassing of weak or unusable batteries within the main pack.

\section{$\underline{\text { Switchgear }}$}

Unlike the switchgear for a standby generator, the continuous backup power system does not use an automatic transfer switch (ATS). An ATS connects the load either to the generator or to the grid, but never to both at the same time. The continuous backup system connects both the grid and the generator to each other and to the load, and only disconnects from the grid when the system is to be islanded from the grid.

The low-cost switchgear used in the European version of Ecopower is a basic IEC rated air-break contactor, three-pole $400 \mathrm{VAC}$ rated. In Europe, contactors are selected according to rating expected during normal operation with provision for certain overloads. In order to minimize the contactor size, they are usually used in conjunction with protective relaying, circuits and 
algorithms so that the contactor does not have to break under full load. In this way the air-break contactor can be sized very close to the normal operation. The US version of Ecopower most likely would use a larger air-break contactor along with a control algorithm and protective relaying according to UL Standards.

Conventional switchgear can have protective relaying as part of the hardware. With the Ecopower system a simple dumb contactor is used in combination with the Ecopower control algorithm to accomplish the same function. This saves the user about $\$ 1,100$ in hardware costs. The system would be 5-10\% more expensive with a traditional ATS (Automatic Transfer Switch). This assumes that the governing bodies in the US will embrace the technology of using a dumb contactor used in conjunction with a microcontroller and software protective functions to operate properly. There is precedent for this already. In the drives industry, software is used in lieu of a Eutectic Overload for Motor Protection and serves to satisfy Article 430 of the National Electrical Code. When a drive is not employed, a separate relay is required to provide this motor protection. In addition, The Ecopower system would have to Pass UL 508 and also UL 1771 for grid connection and regenerated energy.

\subsection{System Packaging}

The modular packaging approach is considered to be the most practical for a residential CHP system comprising thermal storage, DHW, and HVAC. While a unitary package may be practical for a residential CHP system comprising only hydronic heating via a distributed heating system (e.g., radiant heating), the need to incorporate the additional functions of the air handler, DHW storage, and desiccant dehumidifier would result in a large and cumbersome package. Moreover, it would preclude the opportunity to customize the system for non-standard DHW or HVAC requirements. The proposed modular approach accommodates both standard and custom DHW/HVAC designs, while retaining the economy and simplicity of a factory-engineered system via the Thermal Interface Module.

A typical layout of the modular system is shown in Figure 28. The engine-generator is located indoors and vented (not shown) through an outside wall. The thermal interface module is shown mounted on a wall in close proximity to the other modules to minimize piping length and thermal losses. The optional desiccant dehumidifier draws process and regeneration air and rejects exhaust air through an outside wall ${ }^{12}$. It supplies dehumidified air to the inlet plenum of the air handler. The condensing unit of the air-conditioner and the engine auxiliary radiator (not shown) are located outdoors, and need not be in close proximity to the other modules.

\footnotetext{
${ }^{12}$ The use of outdoor air for desiccant regeneration was assumed for all energy consumption analyses in this study, as it results in positive house pressurization, which is appropriate for very humid climates. The use of indoor air for regeneration is an option that produces higher desiccant cooling efficiency and lower or negative pressurization.
} 


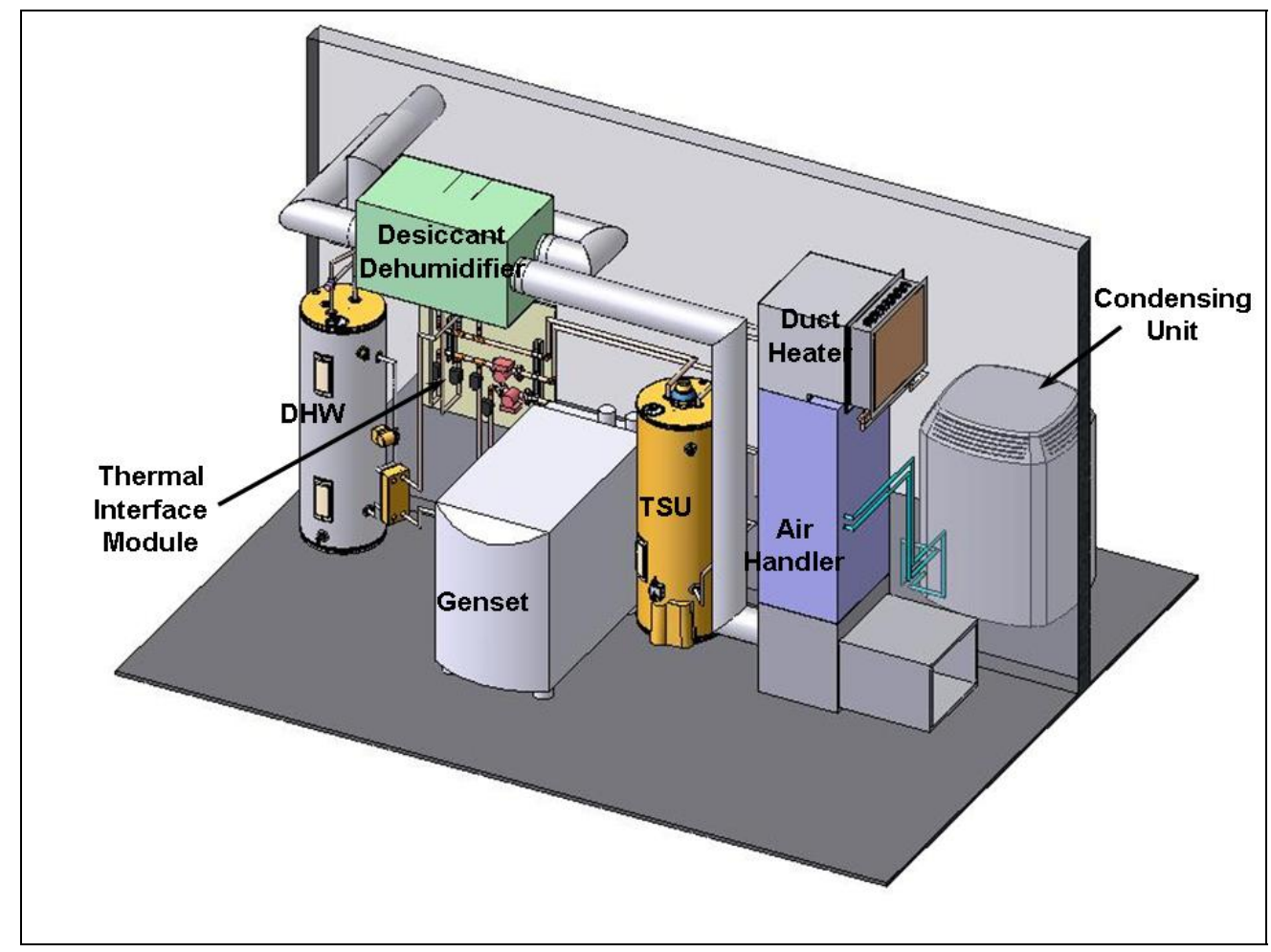

Figure 28. Typical CHP Installation Layout

\subsection{CHP System Cost}

The proposed residential CHP system will provide the heating, cooling, ventilation, dehumidification, and primary and standby power requirements for the home in an integrated package. Its installed cost will depend not just on the cost of the prime mover, but also on the cost of the ancillary HVAC and DHW equipment, which will vary with their performance specifications. In this section, the cost of the CHP system excluding the ancillary HVAC and DHW equipment will first be estimated. Next, the installed cost of a complete CHP system will be estimated and compared to that of conventional non-CHP residential energy systems.

\subsubsection{Ecopower Cost}

The current installed cost a grid-connected Ecopower system is approximately $\$ 22,500$. This includes the engine-generator, engine jacket/exhaust heat recovery, coolant-to-water heat exchanger, controls, and switchgear. Adding islanding capability will increase this cost by approximately $\$ 4,000$ due to the increased cost of the inverter and the added cost of batteries.

The breakdown of costs of the present Ecopower system is shown in Figure 29. The engine and generator together constitute only $25 \%$ of the present cost. The electrical system, including engine and system controls and power conditioning, amounts to $26 \%$ of the cost, and the enclosure is $18 \%$ of the cost. Assembly labor amounts to $10 \%$ of the cost. With the addition of islanding capability, the electrical system will grow to about $38 \%$ of the system installed cost. 


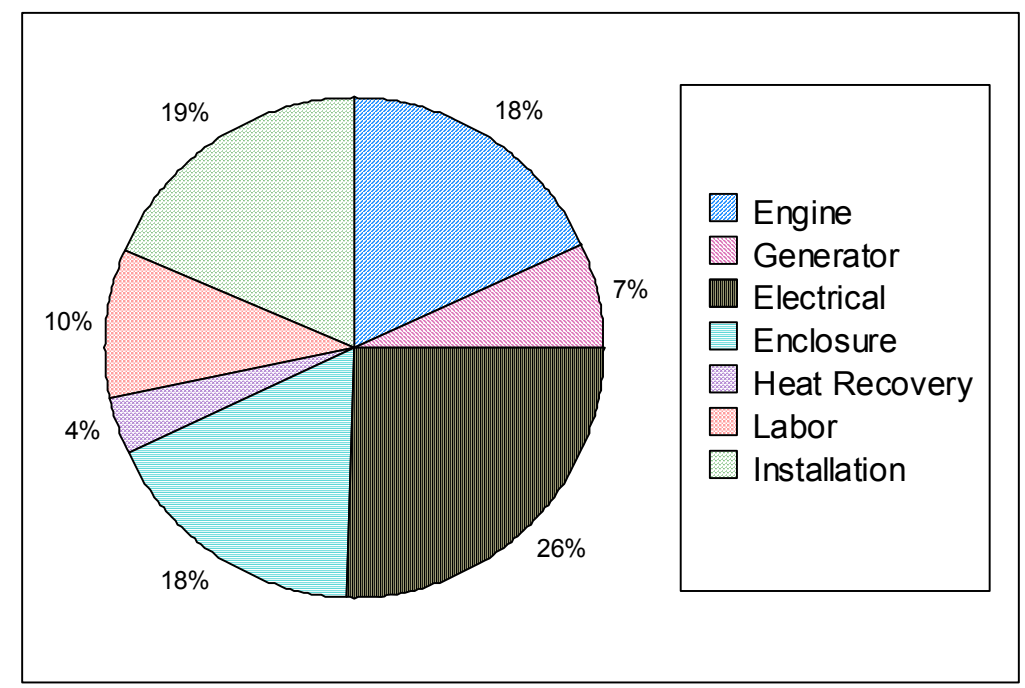

Figure 29. Present Ecopower Cost Breakdown

The present cost of the system is heavily influenced by low production volume and because many of the system components are purchased from Marathon's European partner. As production volume increases so that Marathon may source its own components, many of these costs will drop, especially those of the electrical, enclosure, and heat recovery components. Design improvements should result in further cost reductions. An estimate of high-volume pricing assuming future design improvements and manufacturing efficiencies is quite speculative, but Marathon believes it can bring the installed cost of a continuous backup CHP system down to about $\$ 11,000$ at sufficiently high volumes. The estimated cost breakdown for this scenario is shown in Figure 30.

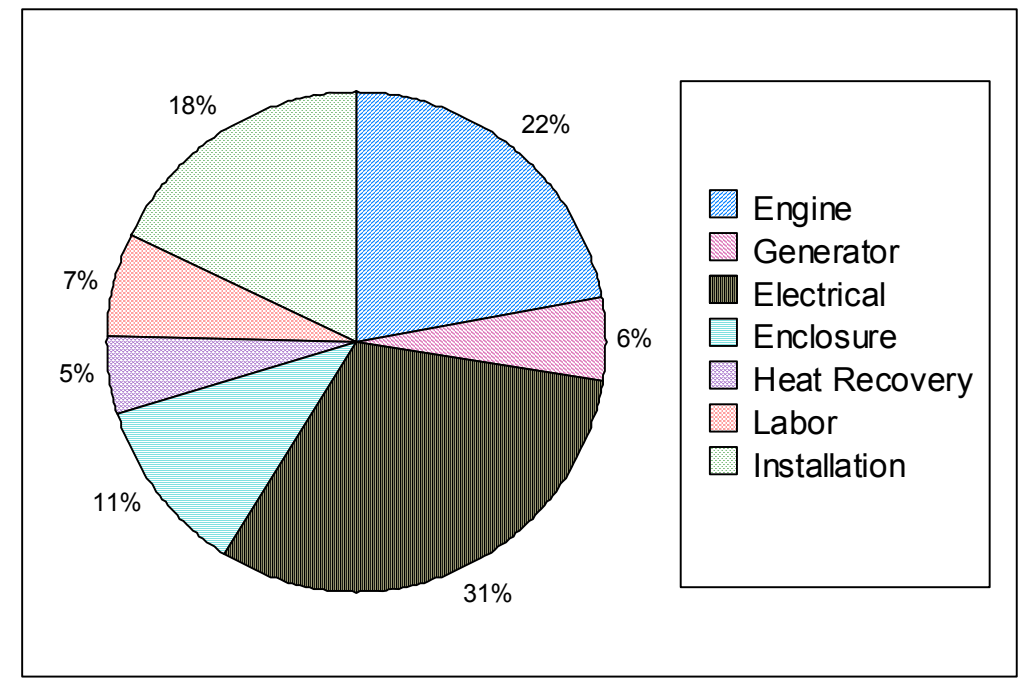

Figure 30. Estimated Cost Breakdown for High-Volume Continuous Backup CHP System 


\subsubsection{Comparative CHP Cost Basis}

The foregoing cost estimate only applied to the installed cost of the co-generation portion of the complete CHP system. It is of greater interest to compare the cost of the complete integrated micro-CHP system to that of conventional non-CHP HVAC/DHW systems that provide similar functions, including backup power. As a preliminary estimate, the purchase price of the HVAC and DHW components will be similar for similar performance features. The difference in installed cost will come from the purchase price of the gen-set, TSU, and thermal interface modules compared to that of a standby generator, and from differences in installation cost.

Unless and until the incremental cost of the micro-CHP system is only marginally greater than that of a conventional HVAC system, its acceptable market price will not be determined on the basis of payback. Based upon the results of the simulation analysis of this project, its annual operating cost savings will be on the order of hundreds of dollars, whereas its near-term installed cost premium will be on the order of several thousand dollars. Rather, its near-term market will be defined by homeowners who are willing to pay a premium for the security of back-up power rather than those who are seeking to reduce their operating costs.

Automatic gas-fired residential standby generators are available at an installed cost in the range of $\$ 8,000$ - $\$ 12,000$. These typically have a higher electrical output than the proposed Ecopower gen-set, in the range of $8-20 \mathrm{~kW}$. However, they are not designed for continuous operation. Furthermore, they do not achieve a level of efficiency that would enable them to provide primary power at an economical cost. Neither do they achieve emission levels comparable to the Ecopower unit.

The Ecopower system is able to match the power capability of larger capacity gen-sets with the supplementary capacity of its battery bank, since all but the most expansive homes have daily electrical loads well below its continuous capacity of $113 \mathrm{kWh} /$ day. Moreover, the Ecopower is able to supply power continuously for an indefinite period, while experience has shown that conventional standby generators cannot be relied upon to function for periods much longer than a week without service, let alone for months.

Homeowners who are seeking the security of backup power for more than several days must purchase primary power generators that utilize heavy-duty industrial engines costing significantly more than standby generators. Most have larger capacities of upwards of $20 \mathrm{~kW}$ and may have additional features, so their price is not easily compared to that of the present system.

This assessment suggests that the proposed system will be price-competitive at two tiers for different market segments. As an energy-efficient alternative to a standby generator, its acceptable installed cost ought to be no higher than that of an equivalent HVAC/DHW system with a standby generator. For those homeowners who are willing to pay a premium for longerterm backup generators that can operate continuously as primary power sources, the acceptable installed price is significantly greater. A price premium in the range of $\$ 20,000-\$ 25,000$ should not be an obstacle for this latter class of purchasers. 
In the near term, the market for the proposed system will likely be limited to the latter upper price tier. In the longer term after production volume enables the price to compete with that of conventional standby generators, the system should meet the requirements of the lower price tier. For the market to become based on attractive payback due to operating cost savings, the annual savings would have to reach the levels of thousands of dollars, which is unrealistic other than in a few instances.

\subsubsection{Installed Cost Estimate}

The methodology used to compare the installed cost of the CHP system to those of conventional non-CHP HVAC/DHW systems was to rely on cost tables compiled for purposes of job-cost estimating for the plumbing and heating trades ${ }^{13}$. These list the costs for equipment, materials, labor and/or subcontracting for installation of residential and commercial HVAC, DHW and standby generator systems. Installed costs were determined for the four systems shown in Table 12. These represent residential systems using a high-efficiency gas furnace for space heating and a gas water heater (Baseline A); using an electric heat pump for space heating and an electric water heater (Baseline B); a CHP system with gas supplementary heating (Gas CHP); and a CHP system with electric supplementary heating (Electric CHP). All systems have similar highefficiency electric air conditioners and dehumidifier/ventilators.

The installed costs are shown in Table 27. The installed prices of all systems included a contractor mark-up of $25 \%$. The CHP systems include a contractor cost of $\$ 19,000$ for the Ecopower engine-generator and a subcontractor installation cost of $\$ 3,500$. The baseline systems include a turnkey subcontractor cost of $\$ 12,500$ for a $10 \mathrm{~kW}$ standby generator ${ }^{14}$. The results show that the installed prices for the CHP systems are $\$ 13,000$ to $\$ 15,000$ higher than the comparable baseline systems at current prices.

It is informative to repeat this comparison with the assumption that the installed price of the Ecopower system is the same as that of the standby generator, i.e., $\$ 12,500$. This might be the case if the cost of the Ecopower can be reduced at higher sales volume. In this case the costs would be as shown in Table 28. Here, the installed costs of the gas and electric CHP systems are comparable to those of their respective baseline systems. Although the thermal interface and hydronic coil add about $\$ 2,400$ to the CHP price, the price of the CHP air conditioner is $\$ 3,100$ less than that of an air conditioner with a high-efficiency gas furnace, and $\$ 1,000$ below that of a heat pump. The prices of the TSU modules roughly offset the prices of the baseline water heaters, so that the remaining price differential is the $\$ 704$ of the DHW module.

This example indicates that, for equivalent engine-generator costs, the price of the gas CHP system is only about $\$ 500$ greater than that of the baseline A system, and the price of the electric CHP system is about $\$ 2,500$ higher than that of the baseline B system, but about $\$ 1,500$ less than that of the gas CHP system. Therefore, if the price of the CHP engine-generator can be reduced to the level of a standby generator, the CHP system should not bear a significant price penalty.

\footnotetext{
${ }^{13} 2006$ CD Estimator, Craftsman Book Company, Carlsbad, CA (www.craftsman-book.com)

14 The estimating source does not break down costs between equipment and subcontractor labor.
} 
Table 27. Installed Costs of Baseline and CHP Systems

\begin{tabular}{|c|c|c|c|c|c|c|c|c|}
\hline & Hours & Material| & Labor & Other & Subcontract & $\begin{array}{l}\text { Total } \\
\text { Cost } \\
\end{array}$ & $\begin{array}{c}\text { Markup @ } \\
25 \% \\
\end{array}$ & $\begin{array}{l}\text { Total } \\
\text { Price } \\
\end{array}$ \\
\hline \multicolumn{9}{|l|}{ BASELINE A } \\
\hline Domestic Hot Water Heater & 7.5 & $\$ 1,289$ & $\$ 240$ & $\$ 0$ & $(\$ 0)$ & $\$ 1,528$ & $\$ 382$ & $\$ 1,910$ \\
\hline $\begin{array}{l}\text { High Efficiency Gas } \\
\text { Furnace/Air-Conditioner }\end{array}$ & 8.7 & $\$ 5,974$ & $\$ 271$ & $\$ 43$ & $\$ 774$ & $\$ 7,062$ & $\$ 1,765$ & $\$ 8,827$ \\
\hline Heat recovery Ventilator & 6.8 & $\$ 1,204$ & $\$ 198$ & $\$ 0$ & $\$ 143$ & $\$ 1,545$ & $\$ 386$ & $\$ 1,931$ \\
\hline Standby power generator & 0 & $\$ 0$ & $\$ 0$ & $\$ 0$ & $\$ 12,500$ & $\$ 12,500$ & $\$ 3,125$ & $\$ 15,625$ \\
\hline Total & 23 & $\$ 8,466$ & $\$ 709$ & $\$ 43$ & $\$ 13,417$ & $\$ 22,635$ & $\$ 5,659$ & $\$ 28,293$ \\
\hline \multicolumn{9}{|l|}{ BASELINE B } \\
\hline Electric Water Heater & 3 & $\$ 394$ & $\$ 90$ & $\$ 0$ & $\$ 174$ & $\$ 658$ & $\$ 165$ & $\$ 823$ \\
\hline Heat Pump & 8.3 & $\$ 4,144$ & $\$ 242$ & $\$ 0$ & $\$ 975$ & $\$ 5,361$ & $\$ 1,340$ & $\$ 6,701$ \\
\hline Heat recovery Ventilator & 6.8 & $\$ 1,204$ & $\$ 198$ & $\$ 0$ & $\$ 143$ & $\$ 1,545$ & $\$ 386$ & $\$ 1,931$ \\
\hline Standby power generator & 0 & $\$ 0$ & $\$ 0$ & $\$ 0$ & $\$ 12,500$ & $\$ 12,500$ & $\$ 3,125$ & $\$ 15,625$ \\
\hline Total & 18.1 & $\$ 5,742$ & $\$ 530$ & $\$ 0$ & $\$ 13,792$ & $\$ 20,063$ & $\$ 5,016$ & $\$ 25,079$ \\
\hline \multicolumn{9}{|l|}{ GAS CHP } \\
\hline TSU Module & 7.5 & $\$ 1,289$ & $\$ 227$ & $\$ 0$ & $\$ 174$ & $\$ 1,689$ & $\$ 422$ & $\$ 2,111$ \\
\hline DHW Module & 2.8 & $\$ 369$ & $\$ 83$ & $\$ 0$ & $\$ 112$ & $\$ 564$ & $\$ 141$ & $\$ 704$ \\
\hline Hydronic Coil & 3 & $\$ 251$ & $\$ 94$ & $\$ 13$ & $(\$ 0)$ & $\$ 358$ & $\$ 89$ & $\$ 447$ \\
\hline Air Conditioner & 6.3 & $\$ 3,620$ & $\$ 183$ & $\$ 0$ & $\$ 774$ & $\$ 4,577$ & $\$ 1,144$ & $\$ 5,721$ \\
\hline Heat recovery Ventilator & 8 & $\$ 1,385$ & $\$ 238$ & $\$ 11$ & $\$ 143$ & $\$ 1,776$ & $\$ 444$ & $\$ 2,220$ \\
\hline Thermal Interface & 9.1 & $\$ 1,149$ & $\$ 283$ & $\$ 0$ & $\$ 143$ & $\$ 1,575$ & $\$ 394$ & $\$ 1,969$ \\
\hline Ecopower & 0 & $\$ 19,000$ & $\$ 0$ & $\$ 0$ & $\$ 3,500$ & $\$ 22,500$ & $\$ 5,625$ & $\$ 28,125$ \\
\hline Total & 36.7 & $\$ \$ 27,062$ & $\$ 1,107$ & $\$ 24$ & $\$ 4,846$ & $\$ 33,038$ & $\$ 8,260$ & $\$ 41,298$ \\
\hline \multicolumn{9}{|l|}{ ELECTRIC CHP } \\
\hline TSU Module & 3 & $\$ 394$ & $\$ 90$ & $\$ 0$ & $\$ 174$ & $\$ 658$ & $\$ 165$ & $\$ 823$ \\
\hline DHW Module & 2.8 & $\$ 369$ & $\$ 83$ & $\$ 0$ & $\$ 112$ & $\$ 564$ & $\$ 141$ & $\$ 704$ \\
\hline Hydronic Coil & 3 & $\$ 251$ & $\$ 94$ & $\$ 13$ & $(\$ 0)$ & $\$ 358$ & $\$ 89$ & $\$ 447$ \\
\hline Air Conditioner & 6.3 & $\$ 3,620$ & $\$ 183$ & $\$ 0$ & $\$ 774$ & $\$ 4,577$ & $\$ 1,144$ & $\$ 5,721$ \\
\hline Heat recovery Ventilator & 8 & $\$ 1,385$ & $\$ 238$ & $\$ 11$ & $\$ 143$ & $\$ 1,776$ & $\$ 444$ & $\$ 2,220$ \\
\hline Thermal Interface & 9.1 & $\$ 1,149$ & $\$ 283$ & $\$ 0$ & $\$ 143$ & $\$ 1,575$ & $\$ 394$ & $\$ 1,969$ \\
\hline Ecopower & 0 & $\$ 19,000$ & $\$ 0$ & $\$ 0$ & $\$ 3,500$ & $\$ 22,500$ & $\$ 5,625$ & $\$ 28,125$ \\
\hline Total & 32.2 & $\$ 26,168$ & $\$ 970$ & $\$ 24$ & $\$ 4,846$ & $\$ 32,007$ & $\$ 8,002$ & $\$ 40,009$ \\
\hline
\end{tabular}


Table 28. Installed Costs of Baseline and CHP Systems for Equal Generator Costs

\begin{tabular}{|c|c|c|c|c|c|c|c|c|}
\hline & Hours & Material & Labor & Other & Subcontract & $\begin{array}{c}\text { Total } \\
\text { Cost } \\
\end{array}$ & $\begin{array}{c}\text { Markup@ } \\
\text { 25\% } \\
\end{array}$ & $\begin{array}{l}\text { Total } \\
\text { Price } \\
\end{array}$ \\
\hline \multicolumn{9}{|l|}{ BASELINE A } \\
\hline Domestic Hot Water Heater & 7.5 & $\$ 1,289$ & $\$ 240$ & $\$ 0$ & $(\$ 0)$ & $\$ 1,528$ & $\$ 382$ & $\$ 1,910$ \\
\hline $\begin{array}{l}\text { High Efficiency Gas } \\
\text { Furnace/Air-Conditioner }\end{array}$ & 8.7 & $\$ 5,974$ & $\$ 271$ & $\$ 43$ & $\$ 774$ & $\$ 7,062$ & $\$ 1,765$ & $\$ 8,827$ \\
\hline Heat recovery Ventilator & 6.8 & $\$ 1,204$ & $\$ 198$ & $\$ 0$ & $\$ 143$ & $\$ 1,545$ & $\$ 386$ & $\$ 1,931$ \\
\hline Standby power generator & 0 & $\$ 0$ & $\$ 0$ & $\$ 0$ & $\$ 12,500$ & $\$ 12,500$ & $\$ 3,125$ & $\$ 15,625$ \\
\hline Total & 23 & $\$ 8,466$ & $\$ 709$ & $\$ 43$ & $\$ 13,417$ & $\$ 22,635$ & $\$ 5,659$ & $\$ 28,293$ \\
\hline \multicolumn{9}{|l|}{ BASELINE B } \\
\hline Electric Water Heater & 3 & $\$ 394$ & $\$ 90$ & $\$ 0$ & $\$ 174$ & $\$ 658$ & $\$ 165$ & $\$ 823$ \\
\hline Heat Pump & 8.3 & $\$ 4,144$ & $\$ 242$ & $\$ 0$ & $\$ 975$ & $\$ 5,361$ & $\$ 1,340$ & $\$ 6,701$ \\
\hline Heat recovery Ventilator & 6.8 & $\$ 1,204$ & $\$ 198$ & $\$ 0$ & $\$ 143$ & $\$ 1,545$ & $\$ 386$ & $\$ 1,931$ \\
\hline Standby power generator & 0 & $\$ 0$ & $\$ 0$ & $\$ 0$ & $\$ 12,500$ & $\$ 12,500$ & $\$ 3,125$ & $\$ 15,625$ \\
\hline Total & 18.1 & $\$ 5,742$ & $\$ 530$ & $\$ 0$ & $\$ 13,792$ & $\$ 20,063$ & $\$ 5,016$ & $\$ 25,079$ \\
\hline \multicolumn{9}{|l|}{ GAS CHP } \\
\hline TSU Module & 7.5 & $\$ 1,289$ & $\$ 227$ & $\$ 0$ & $\$ 174$ & $\$ 1,689$ & $\$ 422$ & $\$ 2,111$ \\
\hline DHW Module & 2.8 & $\$ 369$ & $\$ 83$ & $\$ 0$ & $\$ 112$ & $\$ 564$ & $\$ 141$ & $\$ 704$ \\
\hline Hydronic Coil & 3 & $\$ 251$ & $\$ 94$ & $\$ 13$ & $(\$ 0)$ & $\$ 358$ & $\$ 89$ & $\$ 447$ \\
\hline Air Conditioner & 6.3 & $\$ 3,620$ & $\$ 183$ & $\$ 0$ & $\$ 774$ & $\$ 4,577$ & $\$ 1,144$ & $\$ 5,721$ \\
\hline Heat recovery Ventilator & 8 & $\$ 1,385$ & $\$ 238$ & $\$ 11$ & $\$ 143$ & $\$ 1,776$ & $\$ 444$ & $\$ 2,220$ \\
\hline Thermal Interface & 9.1 & $\$ 1,149$ & $\$ 283$ & $\$ 0$ & $\$ 143$ & $\$ 1,575$ & $\$ 394$ & $\$ 1,969$ \\
\hline Ecopower & 0 & & $\$ 0$ & $\$ 0$ & $\$ 12,500$ & $\$ 12,500$ & $\$ 3,125$ & $\$ 15,625$ \\
\hline Total & 36.7 & $\$ 8,062$ & $\$ 1,107$ & $\$ 24$ & $\$ 13,846$ & $\$ 23,038$ & $\$ 5,760$ & $\$ 28,798$ \\
\hline \multicolumn{9}{|l|}{ ELECTRIC CHP } \\
\hline TSU Module & 3 & $\$ 394$ & $\$ 90$ & $\$ 0$ & $\$ 174$ & $\$ 658$ & $\$ 165$ & $\$ 823$ \\
\hline DHW Module & 2.8 & $\$ 369$ & $\$ 83$ & $\$ 0$ & $\$ 112$ & $\$ 564$ & $\$ 141$ & $\$ 704$ \\
\hline Hydronic Coil & 3 & $\$ 251$ & $\$ 94$ & $\$ 13$ & $(\$ 0)$ & $\$ 358$ & $\$ 89$ & $\$ 447$ \\
\hline Air Conditioner & 6.3 & $\$ 3,620$ & $\$ 183$ & $\$ 0$ & $\$ 774$ & $\$ 4,577$ & $\$ 1,144$ & $\$ 5,721$ \\
\hline Heat recovery Ventilator & 8 & $\$ 1,385$ & $\$ 238$ & $\$ 11$ & $\$ 143$ & $\$ 1,776$ & $\$ 444$ & $\$ 2,220$ \\
\hline Thermal Interface & 9.1 & $\$ 1,149$ & $\$ 283$ & $\$ 0$ & $\$ 143$ & $\$ 1,575$ & $\$ 394$ & $\$ 1,969$ \\
\hline Ecopower & 0 & & $\$ 0$ & $\$ 0$ & $\$ 12,500$ & $\$ 12,500$ & $\$ 3,125$ & $\$ 15,625$ \\
\hline Total & 32.2 & $\$ 7,168$ & $\$ 970$ & $\$ 24$ & $\$ 13,846$ & $\$ 22,007$ & $\$ 5,502$ & $\$ 27,509$ \\
\hline
\end{tabular}

\subsection{Maintenance Costs}

The Ecopower system requires maintenance every 4000 hours of operation, or at least once a year. Scheduled maintenance will be provided by factory trained technicians, who are most likely employed by the distributor. Scheduled maintenance includes replacing the spark plug, ignition cable, air and oil filters, and oil; replenishing coolant, inspecting the engine generator and batteries; and checking engine and control settings, with particular attention to the exhaust emissions. 
The Ecopower module is equipped with diagnostic telemetry which will be monitored by the factory and/or the distributor. The factory/distributor will be able to remotely diagnose most imminent or actual service requirements and will dispatch a service technician with the requisite skills to remedy the problem.

Owners will be required to purchase maintenance and service agreements in order to retain warranty protection. The annual cost of the service and maintenance agreement is estimated to be approximately $\$ 750$. For annual electric generation of 9,000 to $15,000 \mathrm{kWh}$, this corresponds to a maintenance cost of $\$ .083 / \mathrm{kWh}$ to $\$ 0.05 / \mathrm{kWh}$. It should be noted, however, that this is a fixed cost that will not vary with the hours of operation or electricity produced, provided that the engine operating hours do not exceed 4000 hours per year.

Assuming 3,000 to 4,000 annual operating hours, the estimated engine life before a major overhaul should be 10 to 13 years. The estimated cost of replacing/rebuilding the engine will be approximately $\$ 4,000$ at present pricing, eventually dropping to about $\$ 2,000$ at high production volumes. Assuming that the lower replacement cost would be achieved over this time period, amortization of the cost of engine replacement would be about $\$ 100$ to $\$ 150$ per year at a discount rate of $6 \%$. If the 40,000 hour engine replacement was to be added into the annual maintenance contract, this would add roughly $\$ 0.01 / \mathrm{kW}$ to the maintenance cost. 


\section{Energy Consumption and Operating Cost}

The estimated operating costs of the residential CHP systems were compared to those of baseline non-CHP systems for a 3,000 square-foot, two-story single family house. The house and systems were modeled using the DOE-2 building energy simulation engine running under the eQuest graphical user interface. The temperature of the occupied space was controlled to $72^{\circ} \mathrm{F}$ during the heating season and $75^{\circ} \mathrm{F}$ during the cooling season. Relative humidity in the space was controlled to a range from $45 \%$ to $55 \%$. Building environmental loads were calculated on an hourly basis using location specific weather bin data for 13 cities across the U.S. Weather data files were in TMY or TMY2 hourly format. Internal loads were based on occupancy by 5 people with typical residential end-uses.

The house was continuously supplied with a $200 \mathrm{CFH}$ flow of outdoor ventilation air. The DOE2 infiltration model was based on wind speed and a schedule of occupant activity intended to represent the effect of opening and closing doors and windows. The "leakage coefficient" in model was adjusted to result in $200 \mathrm{CFH}$ of infiltration without mechanical ventilation in Miami, $\mathrm{FL}$, corresponding to a natural infiltration rate of $0.5 \mathrm{ac} / \mathrm{h}$ that is typical of newly constructed houses. The annual average infiltration rates predicted by the model were significantly reduced in all locations when the simulation was run with 200 CFM pressurization of the conditioned space.

Annual energy consumption was modeled for the baseline home in 13 cities for the following four energy systems: (1) gas and (2) electric baseline (non CHP) HVAC; and gas-fired CHP with (3) gas supplemental heating and (4) electric supplemental heating. Details of the four systems are shown in Table 12. The total annual energy cost results were presented in Section 3 for all 13 cities. Energy costs were based on the utility rates for each city as obtained from current tariff data published on utility company web sites in early spring 2005 . There is considerable variation in rates and rate structures across the country. Rate structures can be as simple as uniform unit energy costs plus monthly charges, or as complicated as seasonally varying time-ofuse rates. These details were captured in the DOE-2 rate models as appropriate for each city.

The engine-generator was modeled at a constant electric generation efficiency of $22.5 \%$ (based on fuel higher heating value) and $60 \%$ recovered heat, giving an overall thermal efficiency of $82.5 \%$. The maximum electrical and thermal outputs were $4.7 \mathrm{~kW}$ and $12.5 \mathrm{~kW}$, respectively.

The air conditioner was modeled as a 14 SEER 4RT unit with a single speed compressor. The specified performance at ARI rating conditions $\left(95^{\circ} \mathrm{F}\right.$ outdoor dry bulb \& $67^{\circ} \mathrm{F}$ indoor wet bulb) was $50,300 \mathrm{Btu} / \mathrm{h}$ with a COP of 3.61. This was based on Trane data for their XL 14i outdoor unit. DOE2 includes models to determine performance at any combination of outdoor and indoor conditions based on the specified performance at the ARI rating point. This model closely matched the performance data provided by Trane. The electric heat pump used in the Baseline-B simulation was modeled to have cooling performance as specified above, but with heating COP of 2.78 and $9 \mathrm{~kW}$ of supplemental resistive heating. System fans were modeled as variable speed, draw through type with 53\% total efficiency. The nominal flow rate was 1600 $\mathrm{cfm}$. 
The desiccant system was modeled in two parts. The DOE2 solid desiccant system model was used to determine the thermal performance. The model was limited to four possible system configurations with the ability to specify heat exchanger effectiveness and pressure drop. Desiccant wheel performance was fixed by the model and could not be modified to reflect higher performance desiccant materials, so the desiccant system performance was conservative compared with the current state-of-the-art. The electrical input model used by DOE2 was also fixed and reflected a large commercial sized system. As a result, a secondary electrical system model was developed based on data for the AirXchange system. An electrical part load ratio calculated from the DOE2 data was used to scale the full load electrical requirement of the AirXchange system.

In the Baseline-A simulation the warm air furnace was modeled as a $92 \%$ efficient $80,000 \mathrm{Btu} / \mathrm{h}$ unit. The baseline gas-fired hot water heaters were modeled as $80 \%$ efficient with a tank UA of 8.29 Btu/h-F to account for standby losses. Electric units were modeled as $100 \%$ efficient with UA of $1.33 \mathrm{Btu} / \mathrm{h}-\mathrm{F}$. The TSU thermal storage tanks were modeled similarly for the micro-CHP simulations to account for their standby losses. The supplemental heating unit in the micro-CHP simulations was modeled as either an $80 \%$ efficient gas-fired $40,000 \mathrm{Btu} / \mathrm{h}$ boiler, or as a $98 \%$ efficient electric boiler of the same capacity.

One limitation of the DOE-2 model in this instance was that the solid desiccant model available in DOE-2 is for a very basic system with relatively low COP. In Miami, the average COP of the DOE-2 desiccant model is about 0.7 . The performance of the desiccant system being designed for this project is somewhat higher, at 0.5 tons of cooling at a COP of about 0.8 . Thus, the DOE2 simulation provided a somewhat conservative estimate of the cooling performance of the basic configuration of the proposed desiccant ventilator. The performance the micro-CHP desiccant ventilator system configured to use indoor air for regeneration is increased to about 0.9 tons at a COP of 1.7, and to about 1 ton at a COP of 1.8 if evaporative cooling is used to cool the sensible heat exchanger on the regeneration-side. Therefore, the simulation significantly underestimated the performance of these configurations. In all other respects, the DOE-2 model adequately simulated household energy consumption.

A comparison of the total annual cooling and heating energy loads calculated by DOE-2 for the 13 cities is presented in Figure 31. Source energy consumption is compared for each system in each city in Figure 32. Source energy is defined as on-site fuel energy input, such as for a gas furnace or the CHP engine, plus off-site fuel used to generate electrical power. The nationwide average source-to-site efficiency of central station power generation and transmission is assumed to be 33\%. For all cities considered except Miami, the micro-CHP system with gas supplemental heating requires less annual source energy than either of the two baseline HVAC systems. The DOE-2 model calculates more energy in Miami for the CHP systems because the majority of the thermal load is for desiccant cooling rather than for space or water heating, and because it uses a low desiccant cooling COP. The overall annual COP of the solid desiccant system modeled in DOE-2 is only about 0.7 , whereas our analysis of the solid desiccant performance would indicate a COP of about 0.9. At the higher COP the micro-CHP system would have used about the same source energy. However, even at the high desiccant COP, annual energy costs for the microCHP system would be higher than for the baseline systems due to Miami's low spark ratio, which is among the lowest in the nation. 


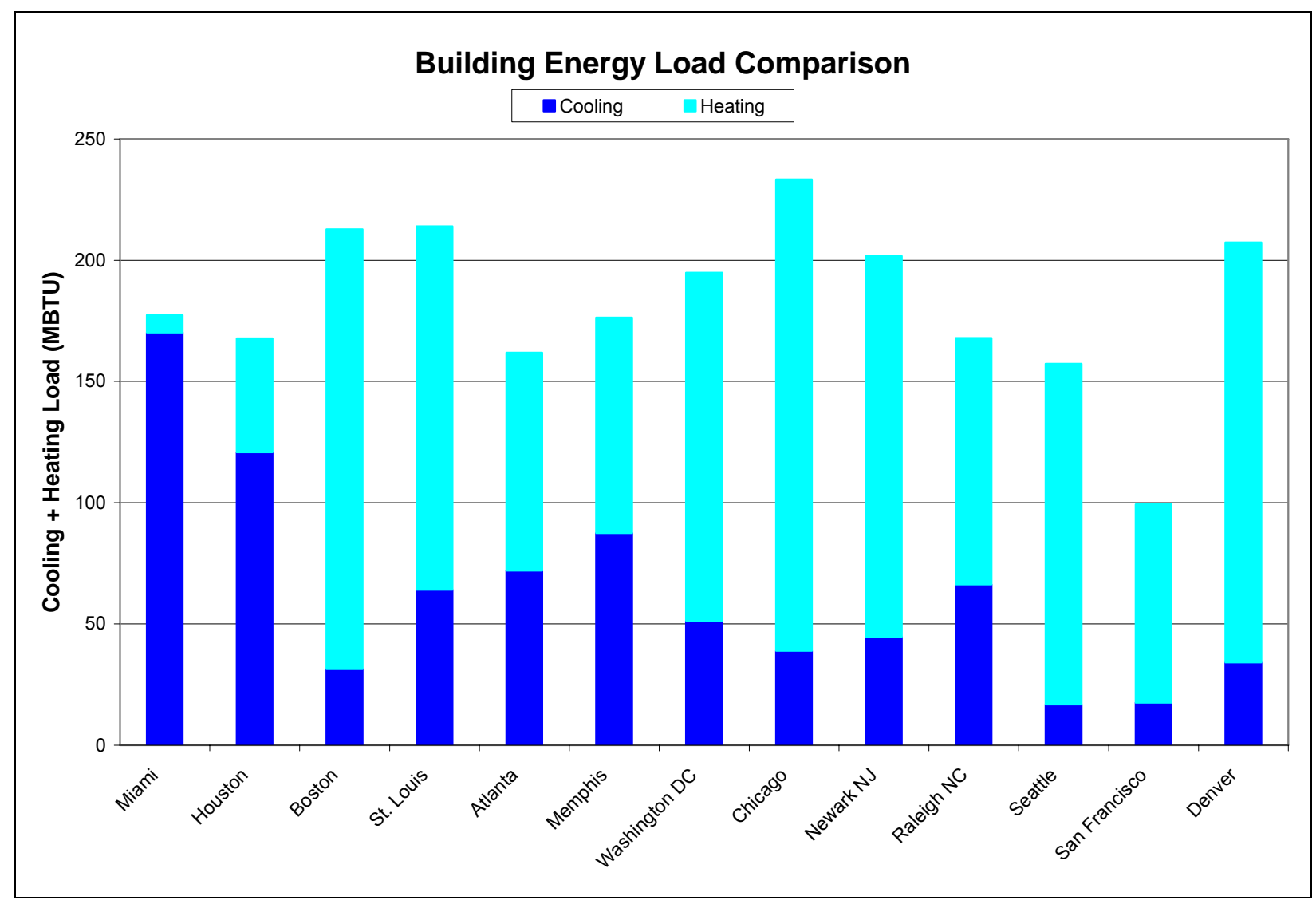

Figure 31. Annual Heating and Cooling Loads in 13 Cities

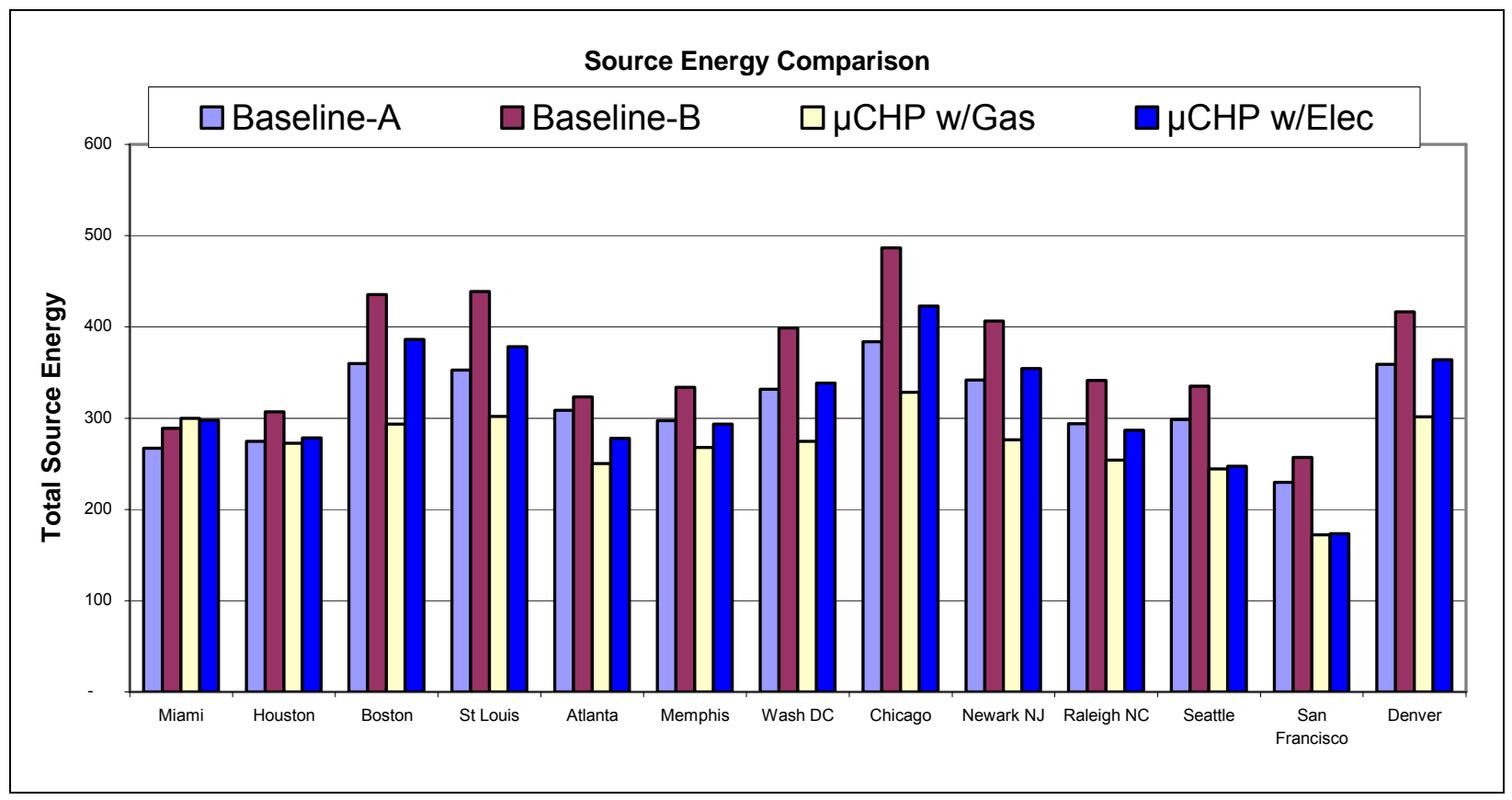

Figure 32. Source Energy Consumption in 13 Cities 
Unlike Miami, Houston has a favorable spark ratio and the total annual space conditioning load for Houston is relatively high. In addition, the total annual latent cooling load is very high, about 30 MBTU out of a 120 MBTU total annual cooling load. The total annual energy costs in Houston for the four systems are compared in Figure 33. Monthly source energy consumption and costs for the four systems are presented in Figures 34 and 35. A detailed energy consumption characterization by end-use is presented in Figures 36 through 39 for the gas Baseline-A and gas micro-CHP systems.

Houston represents a location with good year-round utilization of the micro-CHP system with desiccant cooling. With a modest winter heating load and a significant summer latent cooling load there is a fairly significant year round thermal load that can be satisfied almost entirely by heat recovered from the CHP engine. In the summer months the source energy of the Baseline-A system is marginally lower than that of the micro-CHP systems as currently modeled. However, as described previously, the higher COP desiccant system being designed for this program is expected to result in lower source energy for desiccant cooling than for electric air conditioning. In the winter months the micro-CHP systems clearly use less source energy than either of the baseline systems. The current utility cost structure in Houston results in year-round monthly cost savings for both micro-CHP systems compared to the baseline systems. The largest percentage savings occurs during the heating season. Natural gas and electricity costs are about $\$ 0.92$ per therm and $\$ 0.13$ per $\mathrm{kWh}$ in spring 2005.

Use of the micro-CHP-Gas system clearly reduces the total electrical load during the summer months. This is illustrated by examining the month of July in Figures 36 and 38. The total electrical consumption is reduced from about $2600 \mathrm{kWh}$ in the case of Baseline-A to about 2400 $\mathrm{kWh}$ in the case of micro-CHP-Gas. Further, in the micro-CHP case about $1070 \mathrm{kWh}$ of electricity was generated on-site, which reduced the load on the power grid to about $1330 \mathrm{kWh}$. This is a nearly $50 \%$ reduction from the baseline grid load. The lighting and equipment electrical loads are the same in both cases. There is a significant reduction in the electrical load required for space cooling, which is partially offset by an increase in the required HVAC system fan energy. The micro-CHP system with desiccant dehumidification uses slightly more fan power. This is because the air conditioner operates with higher air flow in order to reduce the latent cooling done by the DX coil. 


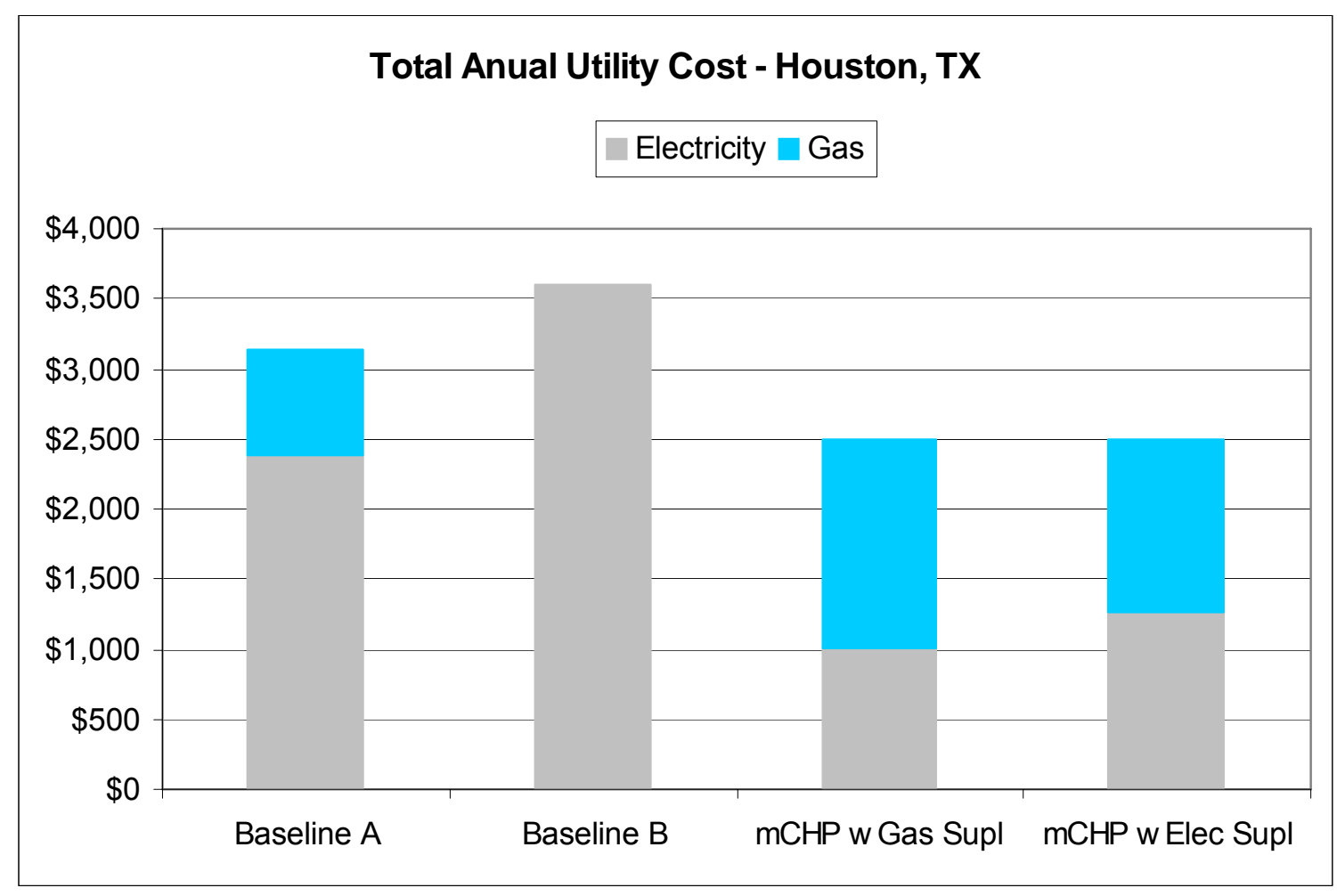

Figure 33. Annual Energy Cost in Houston

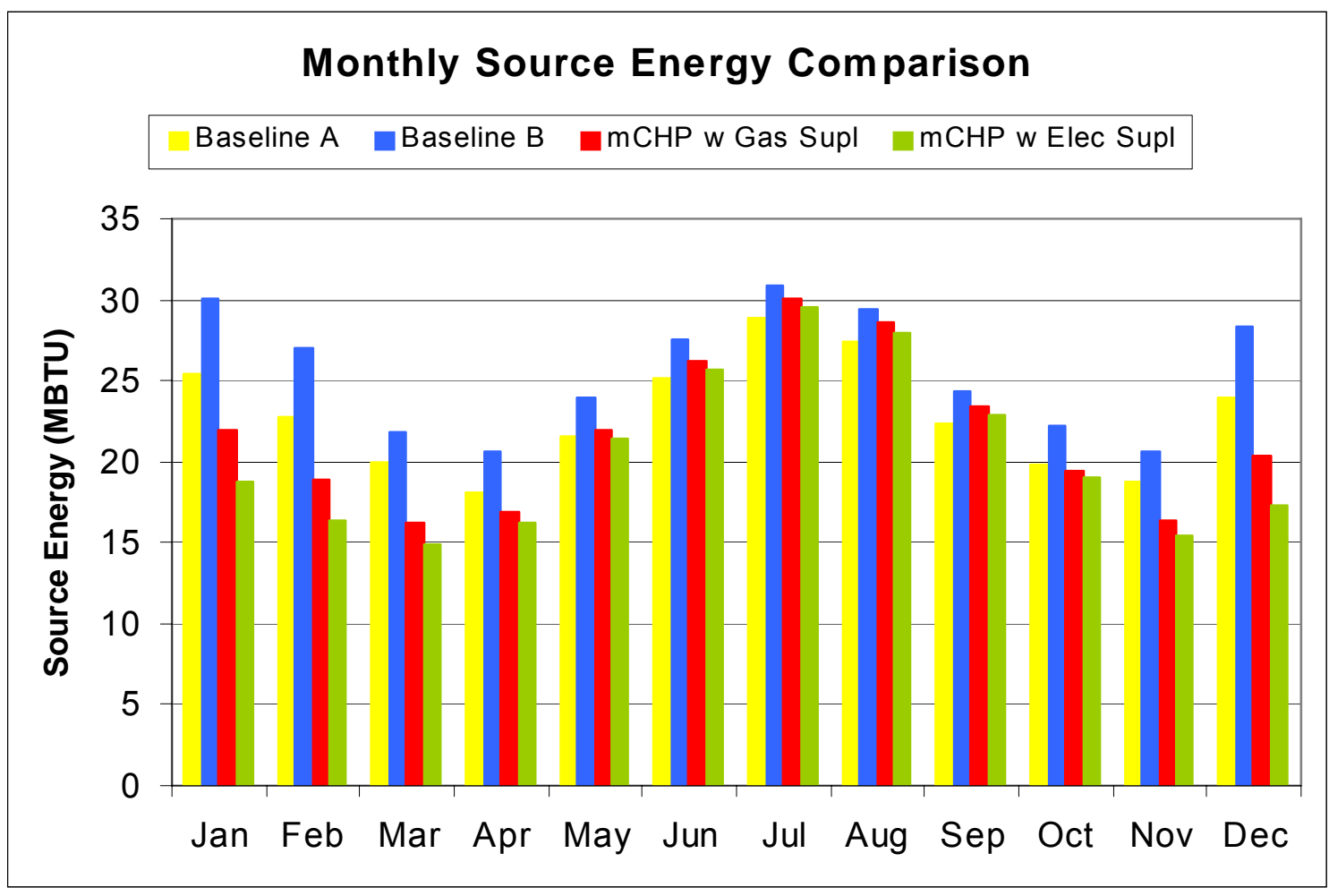

Figure 34. Monthly Source Energy Comparison in Houston 


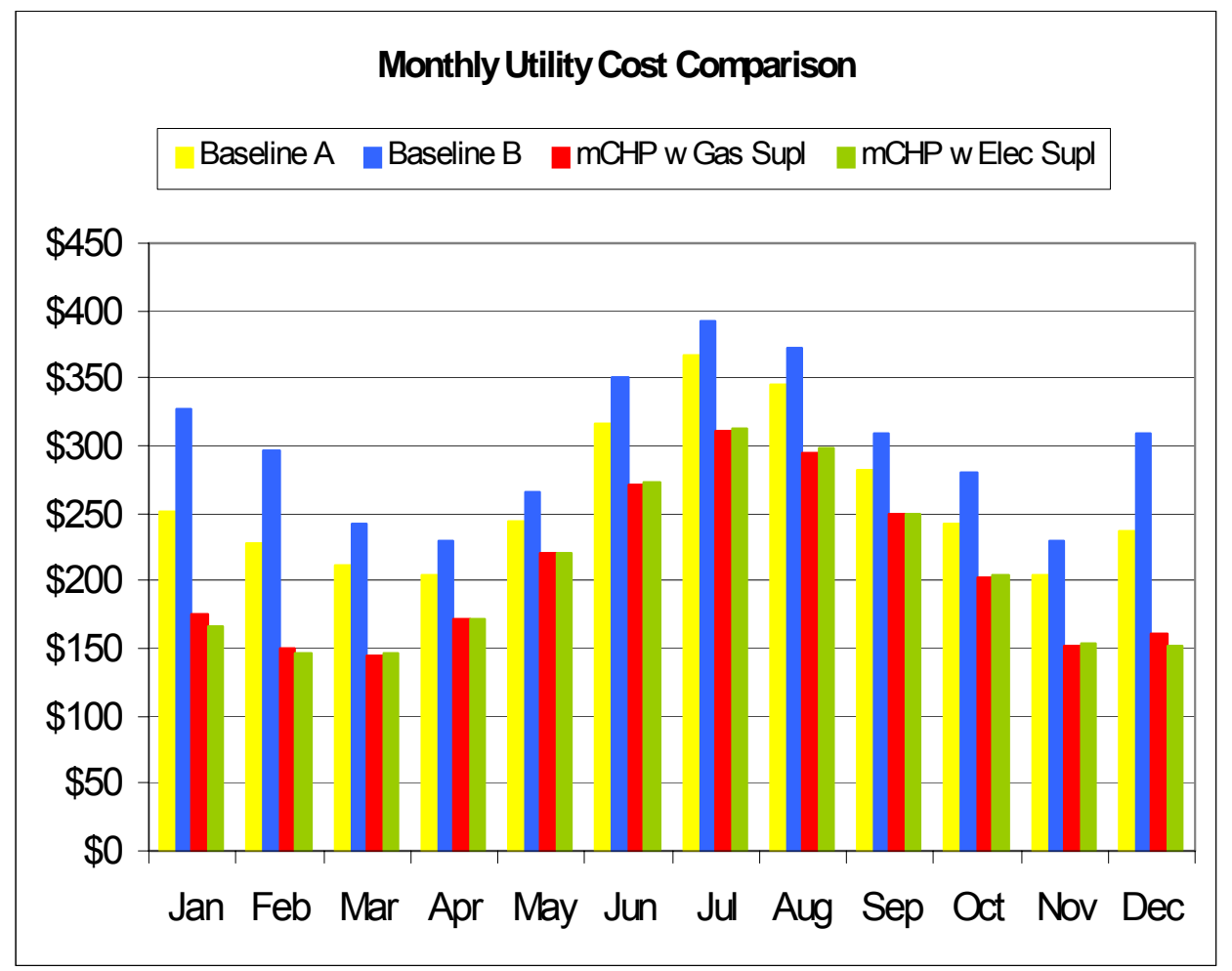

Figure 35. Monthly Utility Cost Comparison in Houston

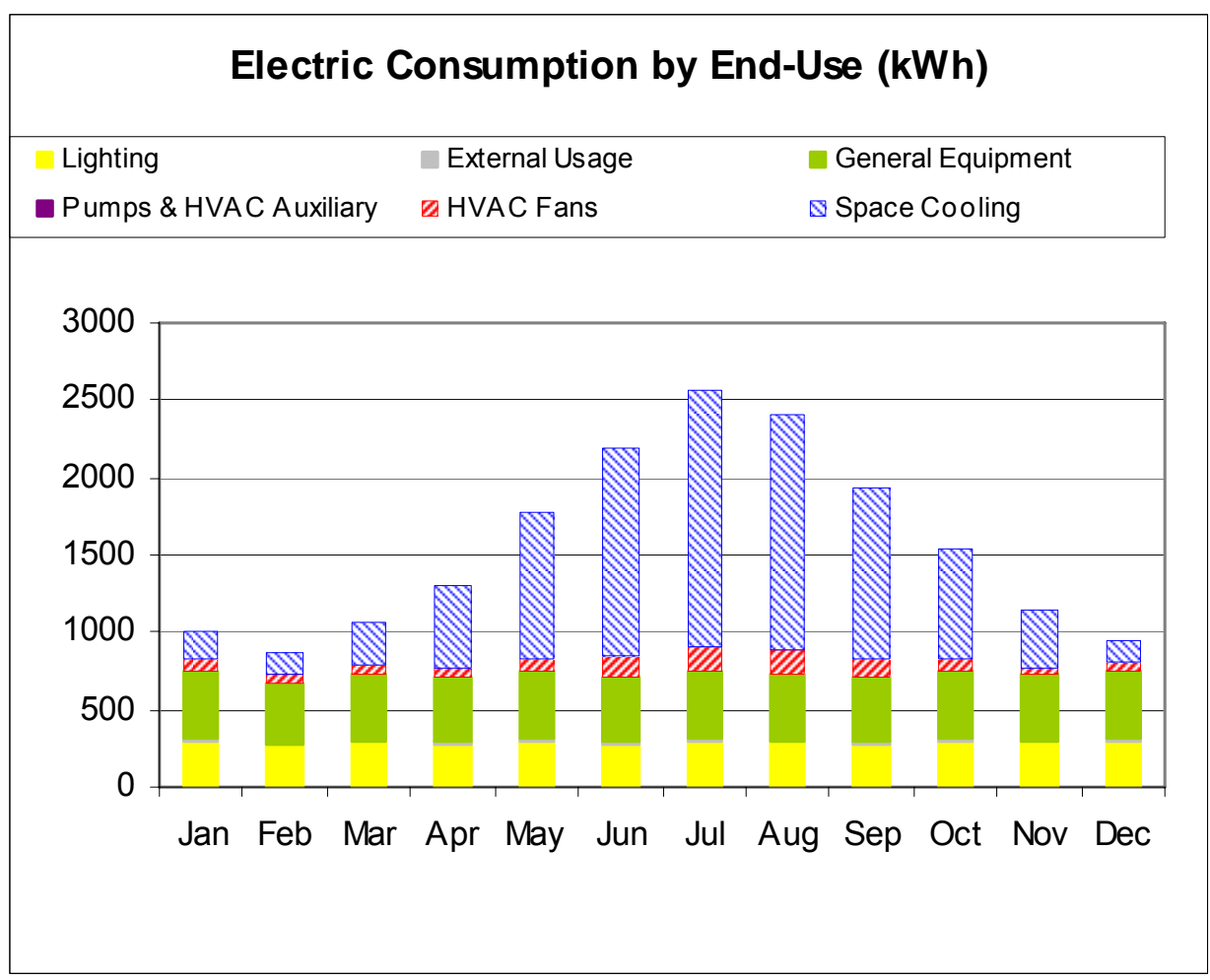

Figure 36. Electric Consumption by End Use for Baseline “ $A$ ” in Houston 


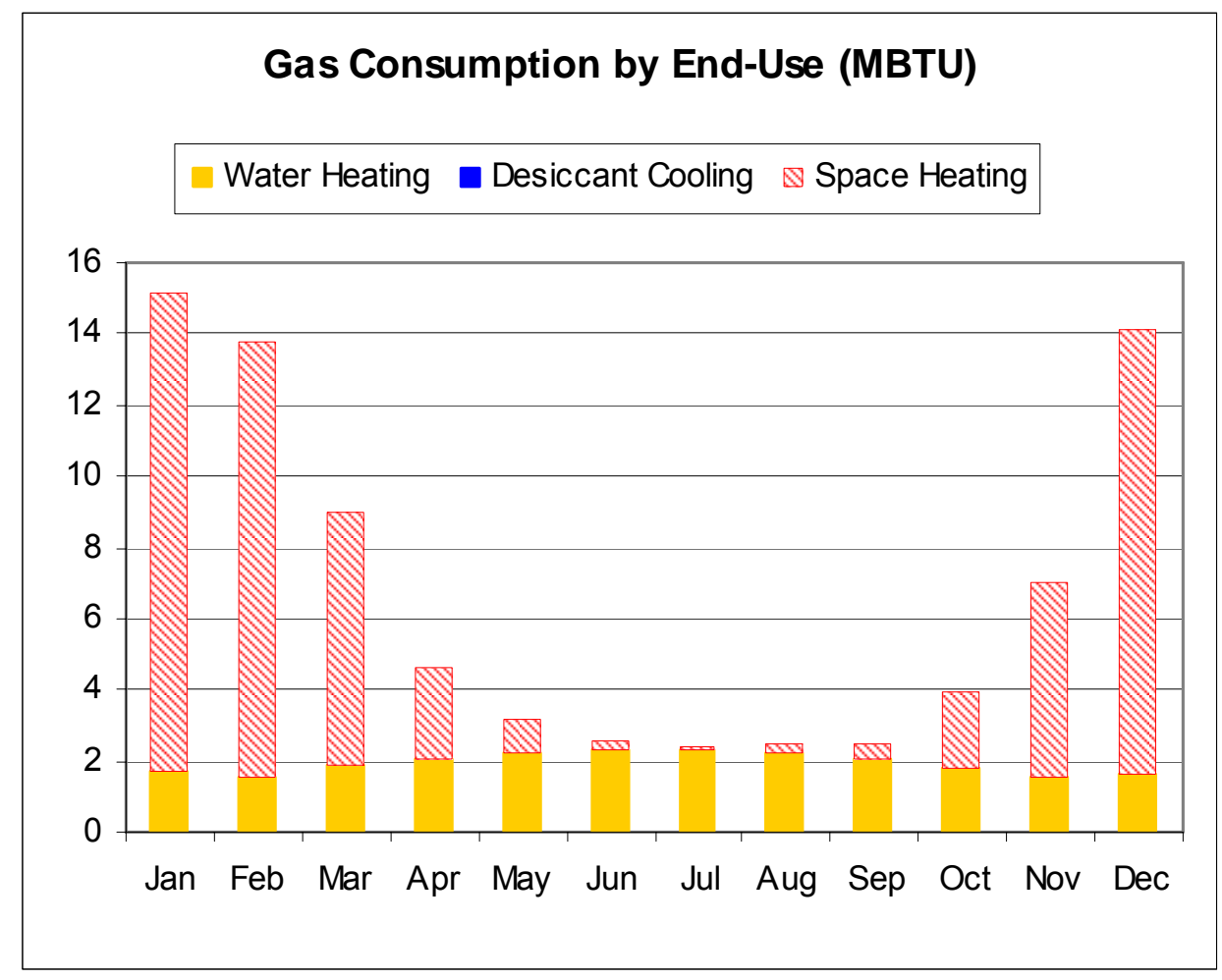

Figure 37. Gas Consumption by End Use for Baseline “A” in Houston

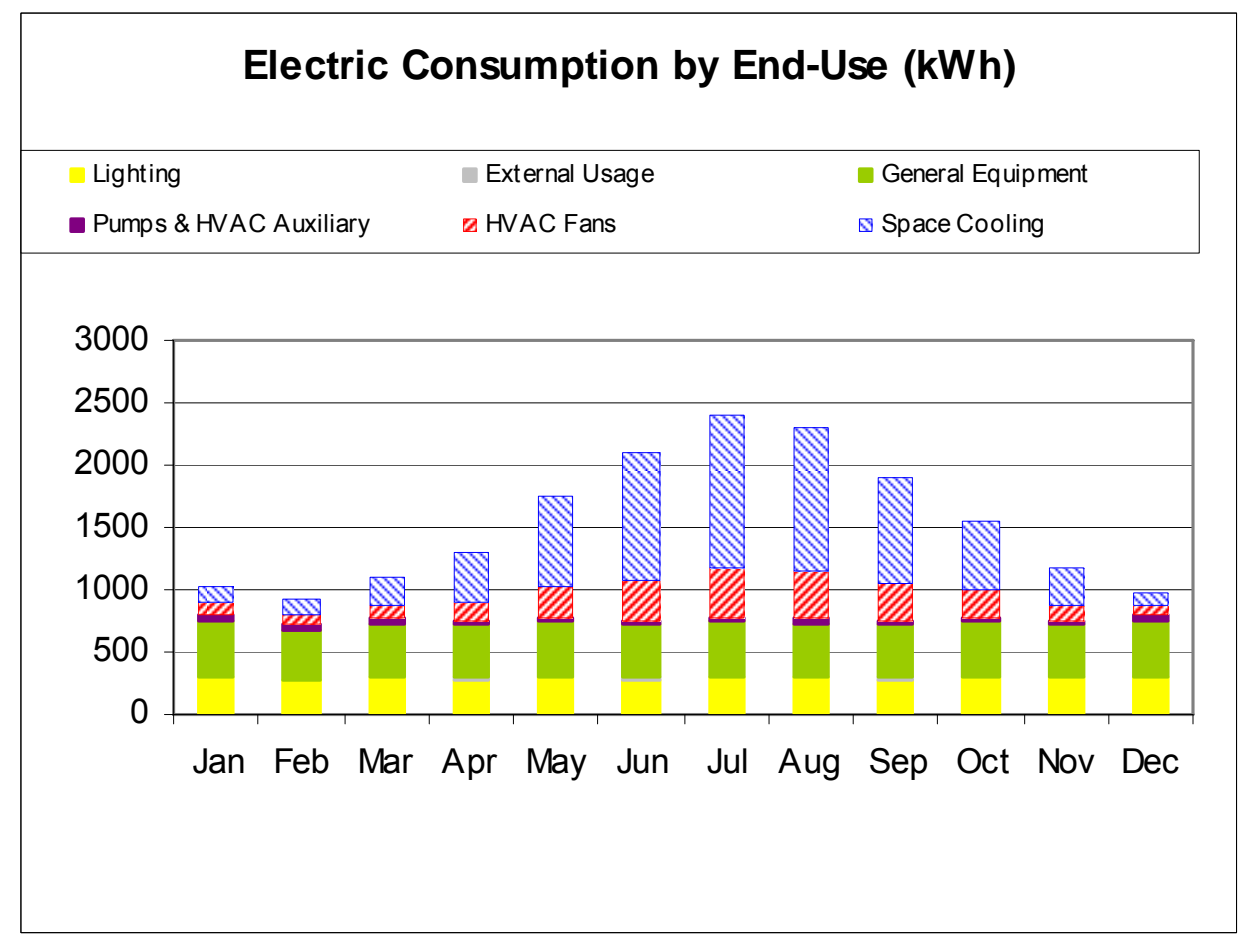

Figure 38. Electric Consumption by End Use for Gas Micro-CHP in Houston 


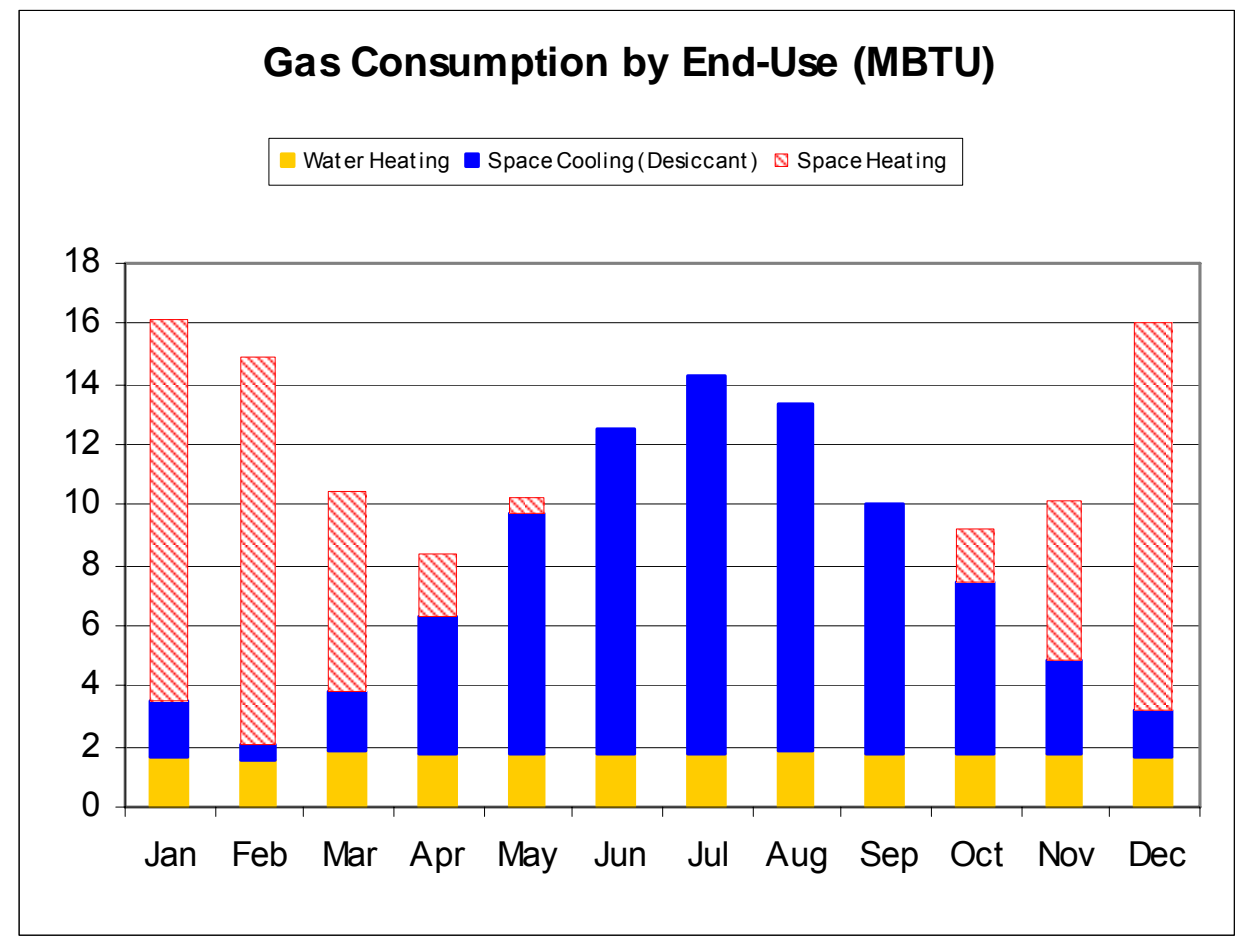

Figure 39. Gas Consumption by End Use for Gas Micro-CHP in Houston 


\section{Commercialization}

\subsection{Micro-CHP Markets}

The markets for the Marathon micro-CHP product line include single and multi-family residences and light-commercial buildings. Both markets include the grid-connected continuous backup type systems and non-grid-connected islanded systems. While the technologies for both systems are quite similar, the market sizes and characteristics are dissimilar.

The grid-connected market is extremely large, and the market drivers are the energy security provided by continuous backup and to a lesser extent the operational savings that accrue from reduced energy consumption. The non-grid-connected market is considerably smaller, and is mostly made up of sites that are remote from existing electric distribution lines or other sources of reliable electricity. Here the market drivers are lower investment and life-cycle costs of micro-CHP compared to extension of electric utility lines.

In addition to residential applications, a sizable market exists in light commercial applications that incur significant thermal and electrical loads, such as restaurants and public houses, medical practices, fitness centers, car washes, nursing homes, and the like. Market drivers are reliability of supply and operating expense, where the latter driver may have a larger influence on account of larger energy loads and expenses.

Micro-CHP is ideal for meeting electric and thermal base loads. In areas where high electric demand charges apply, it can be used to reduce power peaks. When operated in an electric loadfollowing control mode, provision must be made for excess heat rejection. The variable output makes it possible (within limits) to generate only enough electricity to meet the site's own consumption. This is a major advantage where sell-back rates are low.

In addition to micro-CHP there are other non-CHP markets for the same engine/generator technologies that provide revenues and production volumes that benefit the micro-CHP business. Power generation markets include remote power for telecommunications, pipelines, etc. Industrial equipment drive applications take advantage of the Marathon engine's multi-fuel and variable-speed/variable-torque capabilities and its reliability, efficiency, long-life, and lowmaintenance attributes.

Despite the larger size of the grid-connected residential market, we expect that the non-gridconnected micro-CHP and industrial power and drives markets will experience faster and larger penetration in view of their more compelling economics and dramatic benefits. As contractors gain experience and micro-CHP manufacturers gain volume with islanded systems, more gridconnected installations will be facilitated based upon the formers' success stories and manufacturing volume. 


\subsection{Distribution}

As a new technology being introduced into an unfamiliar market, in order for the micro-CHP system to be successful in the mass-market arena, there needs to be a seamless transition from factory through the distribution mechanism and to the end user. The bulk of responsibility for successful application and for user satisfaction will lie with the distributor.

At least in the initial stages of commercialization, the distributor will also specify and install the equipment. This is to ensure competent and knowledgeable application and installation by minimizing the chain of information transfer and between the CHP manufacturer and the enduser. This will also reduce the layers of markup to the end-user price.

As the primary source of knowledge and resource for field support, distributors must be equipped with the tools needed to quality installation and service. This means that they must have the know-how to apply equipment and understand the functionality of the system. They must be able to apply criteria for proper equipment specification and installation, and finally they must carry sufficient inventory necessary for service and maintenance.

\subsection{Sales and Installation}

Residential micro-CHP will not be successful if it fails to satisfy the energy, and comfort requirements of the dwelling as a result of incompetent application or installation. The infrastructure that exists to specify, engineer and install such systems in commercial buildings to support the calculations, planning, placement and settings does not exist in the residential sector. Consequently, homeowners get pulled into the specification of micro CHP units, storage tanks, ancillary heaters, heat exchangers, valving and the sequencing of the entire system.

To move the technology forward as a mass marketed product, the micro-CHP system must be pre-engineered and components pre-specified and equipment selected to meet combined power and HVAC requirements of the dwelling to take proper advantage of the energy, operating cost, and security features of the micro-CHP system. It will be the responsibility of the CHP manufacturer to design standardized production modules, to develop and disseminate the software and system design tools, and to train qualified specifiers and installers. Currently the CHP manufacturer does not have the interdisciplinary skills and the resources to fully prosecute the technology and implement the infrastructure to accomplish mass marketing of a residential CHP product. This capability must be created.

Once the technology and implementation resources have been developed, it is unrealistic to expect that the requisite micro-CHP know-how can be transferred to any one of the traditional HVAC trades that will be involved in the installation and interfacing of the micro-CHP system. We expect that a competently trained micro-CHP sales/installation company will be responsible for specifying, procuring and installing the micro-CHP modules, and will coordinate with the traditional electrical, plumbing, and HVAC trades who will be required to interface their respective distribution and end-use systems with the utilities provided by the micro-CHP system. That entity will be the micro-CHP distributor. 
To equip the distributor/installer to properly specify and configure the micro-CHP system, we envision a software configuration system from a standard PC, which will accept input data describing the residence size, type, construction, heating and cooling loads and living profile. The software will size the system and generate the bill of materials required for the installation, generate a record of appropriate control settings to be input at the jobsite, and will generate the piping and wiring specifications both for the micro-CHP installer and for the trades that must interface their equipment with the micro-CHP system.

\subsection{Service and Maintenance}

Previous experience with engine-driven HVAC equipment has shown that competent and attentive service and maintenance are essential to the market success of such products. Where service and maintenance has been left to the end user or to disinterested third-party providers, equipment has suffered from poor availability and reliability, resulting in owner dissatisfaction.

The Ecopower system requires maintenance every 4000 hours of operation, or at least annually. Owners will be required to purchase maintenance agreements in order to retain warranty protection. Scheduled maintenance will be provided by factory trained technicians, who are most likely employed by the distributor.

The Ecopower module is equipped with diagnostic telemetry which will be monitored by the factory and/or the distributor. The factory/distributor will be able to remotely diagnose most imminent or actual service requirements and will dispatch a service technician with the requisite skills to remedy the problem.

The issue of service for the Micro CHP must be addressed in a complete fashion. This service model is different from most equipment or appliance service models, because the micro CHP system is providing primary power and heat required for safe and comfortable operation of a home. Accordingly, we envision several layers of service resources beginning with a call center that can support questions the user may have on their system. The diagnostic may be remote, and as such, the distributor/contractor may be able to dial up the micro-CHP system and interrogate it for values and conditions. Working with the homeowner user, simple changes and adjustments could be made as a first line of defense in the service toolkit.

Secondly, if a site visit is needed, we envision an interactive diagnostic software that directs the technician to the problem area, module or component and further directs them on replacement instructions, model numbers revision history etc. It basically starts with a top level diagnosis and "walks" the technician down through the decision tree. 


\section{Conclusions and Recommendations}

An assessment has been made of the market, technical requirements, and performance of a micro-CHP system that can provide the power, heating and cooling needs of residential applications. The proposed system is based on an IC-engine generator that has been developed for long life and high efficiency. It features hydronic energy storage and heating for space heating, domestic hot water heating, and latent cooling by desiccant dehumidification.

The conclusions and recommendations of the Phase I study are as follows:

1) The proposed residential micro-CHP system reduces primary energy consumption by $14 \%$ to $26 \%$ compared to high-efficiency conventional HVAC systems and power supplied from the electrical grid. The system achieves an overall energy efficiency of $80 \%$, with an electrical efficiency of about $21 \%$, based on fuel higher heating value. It requires routine maintenance only on an annual basis, and has an expected engine life of 40,000 hours.

2) The market for the proposed micro-CHP system will be larger, new-construction, singlefamily homes. New residential construction is most heavily concentrated in the South and West of the United States, which together account for about two-thirds of new residential construction. However, the proposed system achieves the largest primary energy savings in applications with high space heating loads, which are in colder regions.

3) Thermal load-following with net metering (as opposed to electric load-following) is required for positive energy and cost savings.

4) To minimize cost and to gain acceptance in the marketplace as a reliable, high-quality product, the micro-CHP system needs to be factory engineered and installed and maintained by a qualified installation, service, and maintenance organization.

5) The market driver for residential micro-CHP systems will be the security provided by its ability to supply power and heating loads independent of the electric grid rather than savings in energy costs.

6) Savings in operating costs require a ratio of the cost of electric energy to the cost of gas greater than about 3.0. A "spark ratio" greater than 3.0 occurs in only a few areas of the country, and is currently in a downward trend nationally. Widespread utilization of residential CHP generation requires financial incentives and/or increased spark ratios.

7) The current purchase price of the Ecopower based micro-CHP system is higher than that of a conventional HVAC system with a standby generator. A factor of two reduction in the purchase cost of the engine-generator should lead to significant sales growth of the residential micro-CHP system, and is feasible at a higher production volume.

8) At the present CHP pricing and energy price ratios, the residential CHP market is constrained mainly to non-grid applications and to those applications seeking the added security of "continuous backup" capability. If and when the purchase price of the engine- 
generator can be reduced to the level of a standby generator, the installed cost of the proposed micro-CHP system, including its energy storage and thermal interface, should be competitive with that of a conventional HVAC system with a standby generator.

9) The proposed desiccant ventilator utilizes heat recovered from the engine to provide latent cooling. Its most basic configuration utilizing outdoor air for regeneration does not reduce primary energy consumption on account of its modest cooling coefficient of performance. However, the addition of evaporative cooling and/or the use of indoor air for regeneration should produce positive primary energy savings.

10) The energy and cost saving potentials of the proposed desiccant cooling scheme are constrained by the magnitude of the building's latent cooling load and the limited enthalpy flux that can be conveyed by $200 \mathrm{cfm}$ of ventilation. This utilizes only about 20 percent of the available engine heat. A larger unit processing a mix of ventilation and return air and employing desiccant dehumidification with evaporative cooling could use most or all the available engine heat to provide both sensible and latent cooling, and could produce about 4 times the tonnage. Although this would be more expensive option, it would utilize more of the engine heat in the cooling season and should greatly reduce the need for conventional air conditioning. This option should be studied further, as it may make a desiccant-based CHP system more attractive, especially in humid climates. 